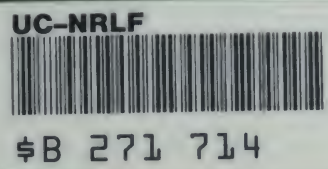




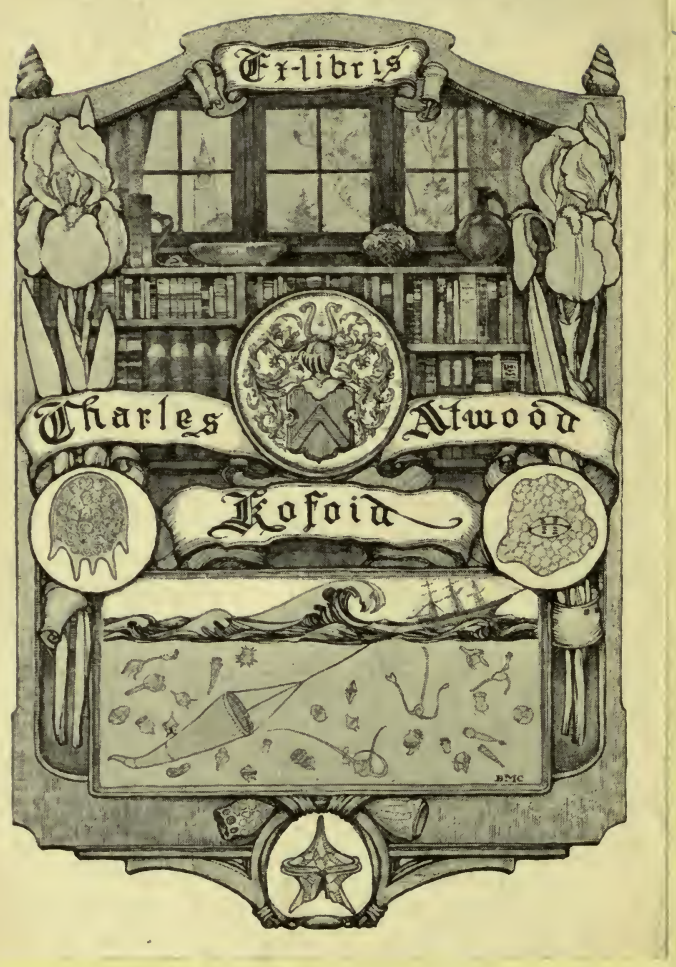




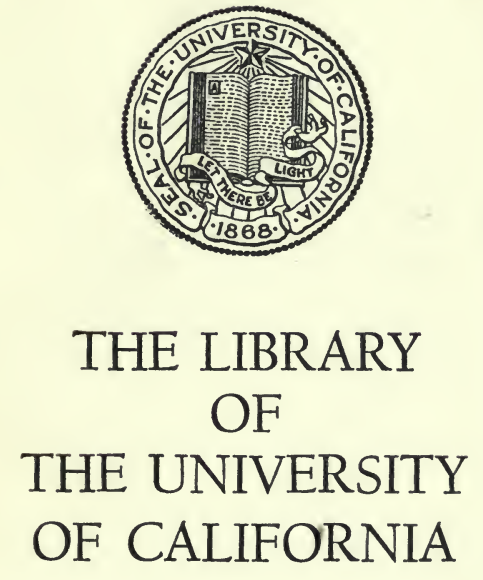

PRESENTED BY

PROF. CHARLES A. KOFOID AND MRS. PRUDENCE W. KOFOID 
Inthent portrait

t 
THE

\section{crue Fióngment}

OF

\section{Angling.}

By HENRY PHILLIPS, Esq.

NE TENTES, AUT PERFICE.

LONDON :

WILLIAM PICKERING, PICCADILLY. MDCCCXLIII. 


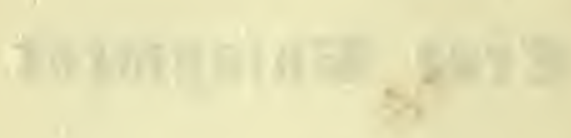

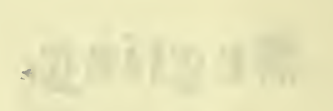




\section{SH 439 $P_{55}$}

My Dear Sir,

With permission, I have the pleasure of dedicating to you this bold but trifling effort, and having originally tempted you to taste the enjoyments of our delightful and harmless sport, I can boast of having added to its votaries one of the most kind, benevolent, hospitable, and admirable of men; a liberal Patron of the Fine Arts, a Lover of sweet sounds, and an Enemy to no one. These are truths seldom to be recorded, but fearlessly put forth by your

Most grateful and true Friend,

\section{THE AUTHOR.}

To Samuel Cartwright, Esq. 



\section{THE \\ TRUE ENJOYMENT \\ OF ANGLING. \\ Ne tentes, AUt PERfice.}


Digitized by the Internet Archive in 2007 with funding from Microsoft Corporation 
THE

\title{
TRUE ENJOYMENT
}

\author{
OF \\ A NGLING.
}

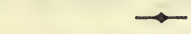

NE TENTES, AUT PERFICE.

England now stands pre-eminent as the school of Anglers"; its varied climate makes acute our senses, its many streams afford fresh pleasures, and the honour of its votaries gives impulse to improvements that are never ending, and our constant thought. It is often said that little new can be placed before the sportsman who has well digested the far famed Izaak Walton. It is true that nothing can surpass his beauty of sentiment, his richness of ideas, or his simplicity, and perfection of life; but, to assert, that our rods are not finer tapered, 
our lines better twined, or our hooks surer tempered, is not true; it is our own tempers, simply, that have not advanced. How frequently have I observed some lonely being seated on the brink of a dull river, or his own preserve, watching a sleepy float, or, muffled in half a dozen coats, poised in a punt off Hampton's royal banks, waiting with wearied eye the bite of a stray Perch-

"Or Barbel, Bream, or what else came athwart, And patience deem perfection of the Art."

"Twas not the fashion, till of late, to imitate so much the simple life of Walton; many attempts have been made to revive those hours, but none successfully; it would almost appear as if the loss of so benevolent and amiable a character had caused a gloom we have but just recovered from.

"Then some high mind, tired of the citie's din, Look'd bold abroad, and found a soul within That lack'd but opportunity to spread afar, And leave a toilsome peace, for intellectual war." 
What can be more delightful, and intellectual than Angling? It combines observation, and skill; to the contemplative mind, Painting, Poetry, and Music. My object in this little book is not to attempt elaborate remarks on the numberless insect tribes, or teach Fishermen the art of manufacturing their own Flies; so many works exist that would far outvie in these respects any poor effort of my own : but simply to place before the reader my observations on the ordinary routine, and to make our recreation better worthy the Angler's study, more amusing, and possibly more elevated, by endeavouring to lead our brother from the Brook to the Easel, from the Pencil to his favourite Poet, thence to his Guitar. And who shall deem his time ill spent, that rising early greets the welcome morn-observes its varied hues, its rare productions, - - has not one evil thought; exercise and health, and more than all, a grateful heart. towards that mighty Being who gave him life 
to pass a day so innocently spent? It may be argued, that you cannot form or expect to find any person conversant with Poetry, Music, and Painting, and devoting, too, a portion of his existence to the practice of Angling. This I deny: the man who can enjoy our delightful recreation is heir to all those finer feelings, or he is no Fisherman at heart; he may not be skilled to execute, but amongst so large a body there will always be found superior Genius exhibiting sufficient knowledge to stimulate the rest. Then rally round our standard; we will teach you gentleness, skill, patience, and reflection.

"Instruct thee how to live-combining toil and healthTo enjoy the Country and the Citie's wealth."

From my earliest youth was I fond of fishing; what boy is not? and, (like that friend on his preserve,) my patience was not easily worn out. If I got a bite once in three hours I was content; and gazed on my prey with all the enthusiasm of an experienced Angler. Here was 
my fondness for the gentle art early displayed; but little did I think how varied were its ways, how much practice and observation it required; how lofty its results, how expanding to the mind, and beneficial to the heart, was the pursuit of Angling. 

MARCH.

$$
\text { в } 3
$$





\section{fflarcb.}

$\mathrm{M}_{\text {arch, }}$ which summons all Nature to dispel her gloomy vapours, warns the Fisher also to awake, prepare his snares, his flies and rods, call into action all the plans laid down in dreary Winter, for the coming Spring; his cunning now he can in practice prove. Mark! how the Trout looks forth with eager eye for the first dainty Fly that tempts him. Still he's wary; for 'tis only when the sun peeps out, or a soft west wind comes stealing on, that he's alert; it lasts not, but passes on, and leaves a thrilling chill behind.

Now must the Angler use his utmost art. The Fly has little colour, it scarce indeed exists, and then its action is but weak; so when you've ascertained its form and tint, let it drop lightly on the water, and draw it softly across 
-it has not strength enough to strive against it; neither let it sink too deep. The Flies which now exist are light and buoyant; jerk them a little, and if a Trout rise, strike hard. He will bite bold, yet in. his eagerness oft miss; so, if you feel him, strike hard. The March Brown is the acknowledged Fly for this month; the Grey, and Black Gnat are also likely to secure good sport. So I'll give you three fair brace of Trout for your first day's toil. You shall have fagged, are tired, repaired to your Inn, and, seated with your companions round a comely fire, chaunt this after-strain in anticipation and praise of a March day. 


\section{SONG.}

Is the Sun up? is't approach of morn?

Is it the moan of the cowherd's horn?

Is't the shepherd's bell which greets mine ear?

Is't the rustling step of the Fawn and Deer?

Is't the dancing stream where the Fishes play?

Or the bracing breath of a young March day?

Yes, the Sun is up, and the Fly is out

That will tempt the eye of a golden Trout.

Let thy skill be good, and thy line be strong,

And the prey shall be thine, ere the morn be long;

Yet be cautious, and quick, nor approach too near,

In this timid and early month of the year.

So arouse thee, be stirring, thy tackle prepare, And prove well the strength of each separate snare.

Thou hadst better be wanting a single brace, Than harness a Fish with a worn-out trace.

Then may joy, and success, and no ills betide The repast, and repose, of thy bright fireside. 


$$
\text { P. }
$$



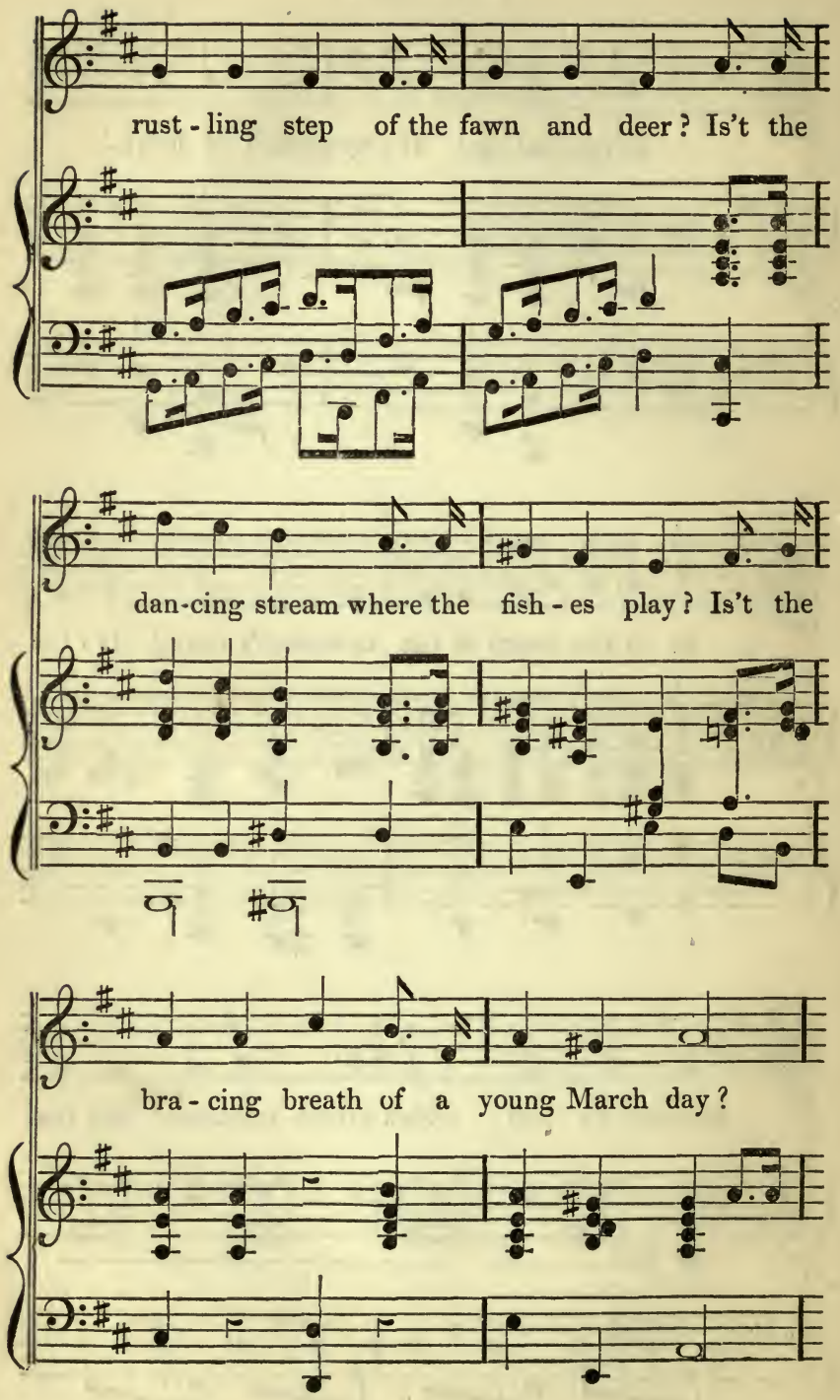

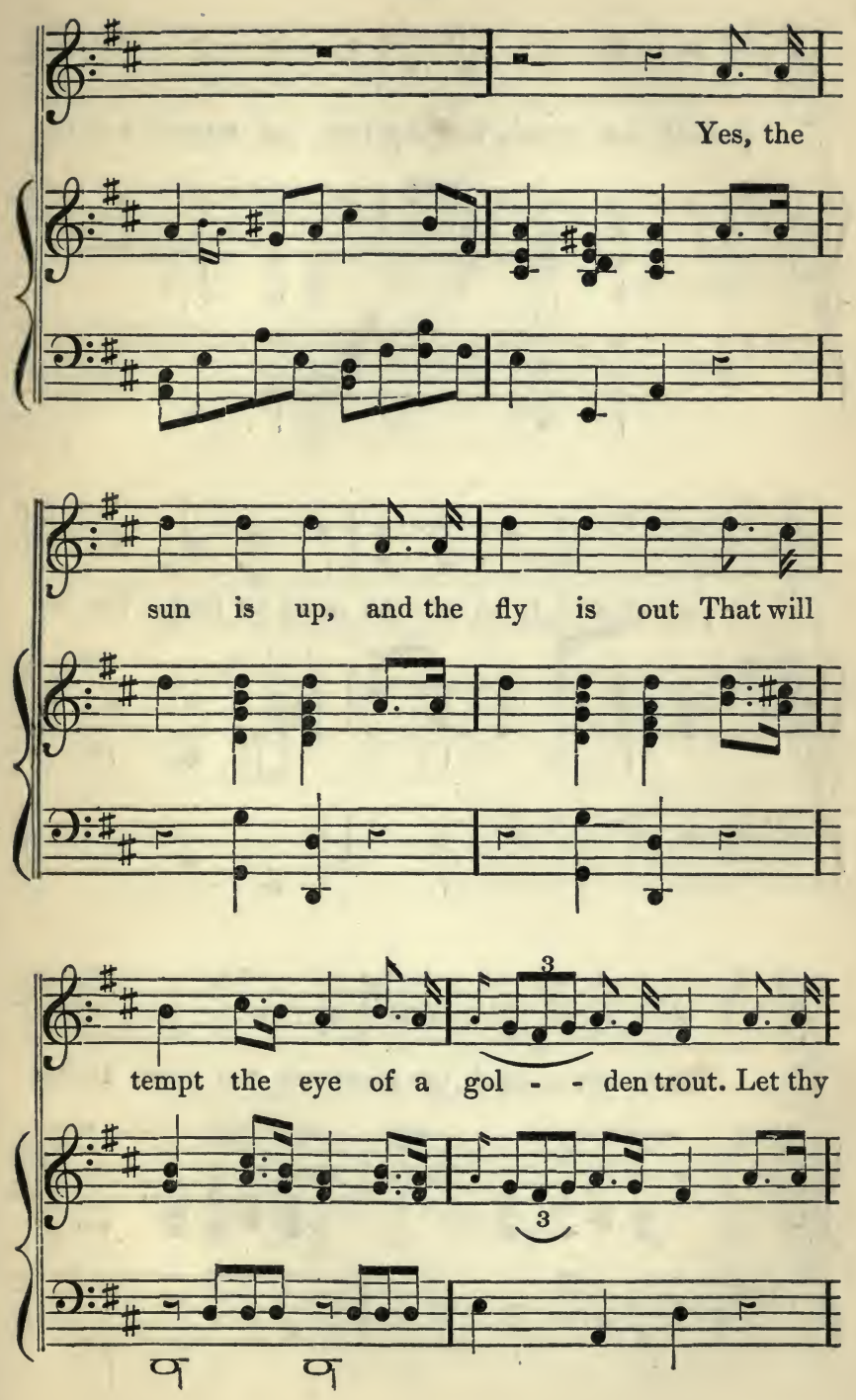

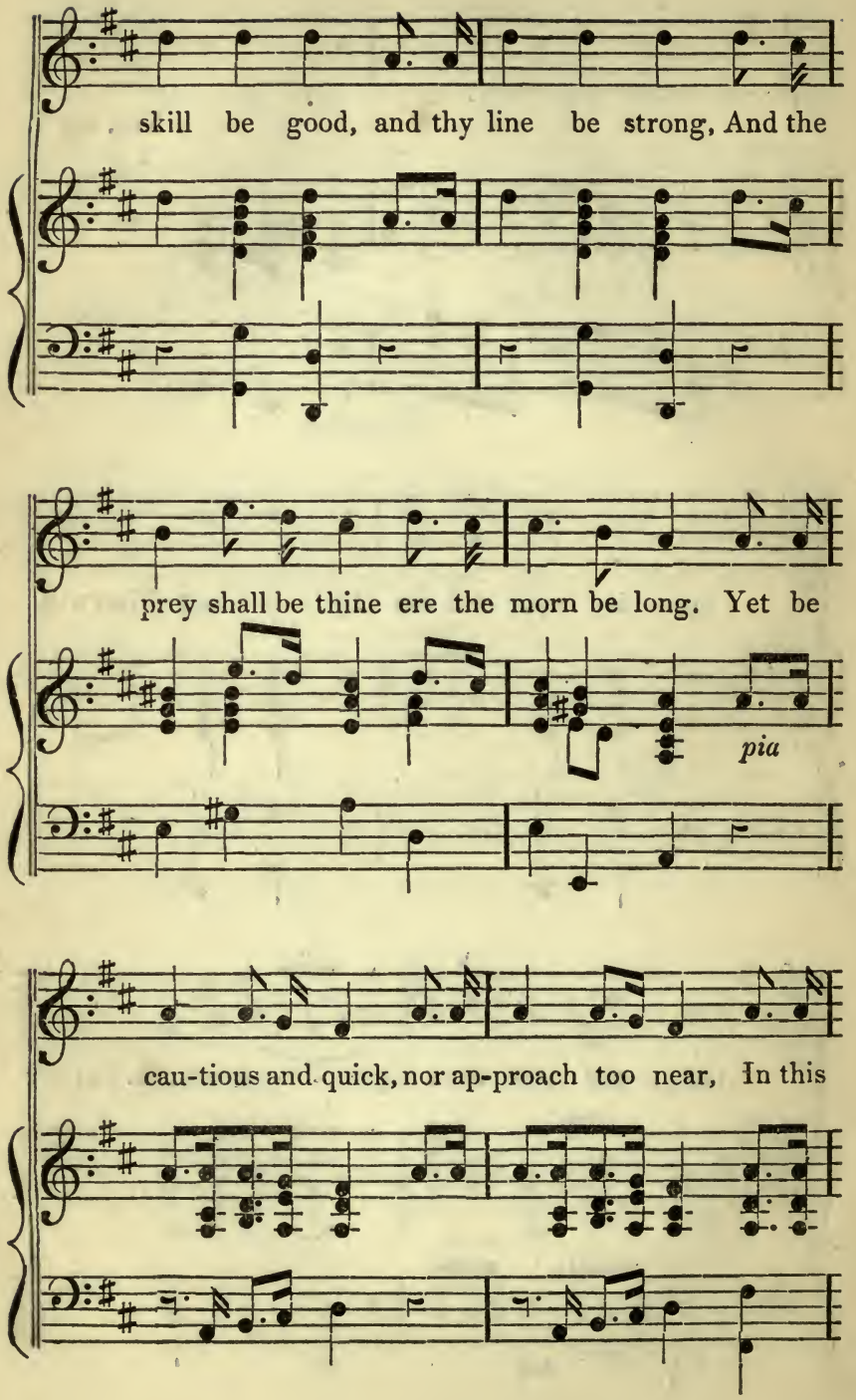


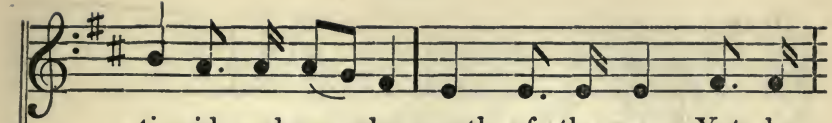

.. ti-mid and ear-ly month of the year-Yet be
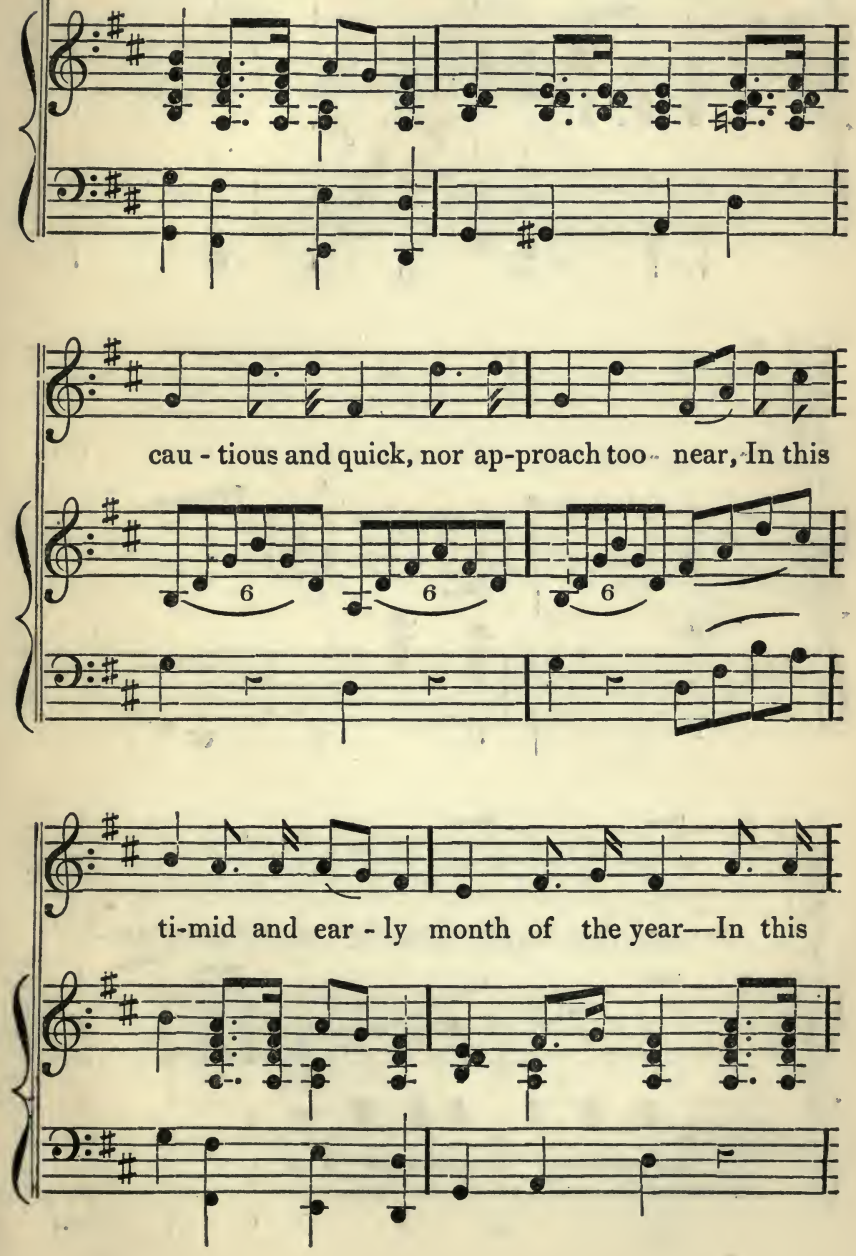


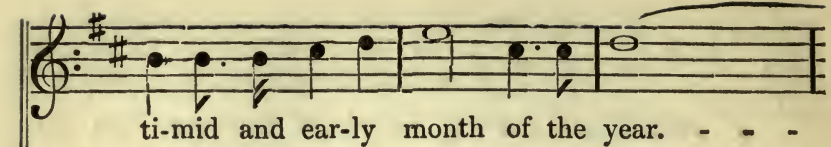

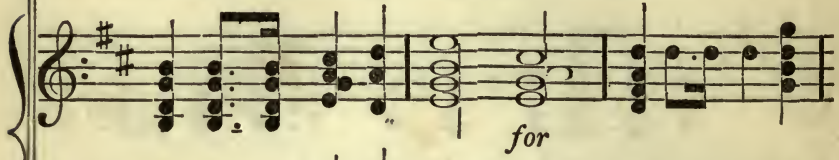
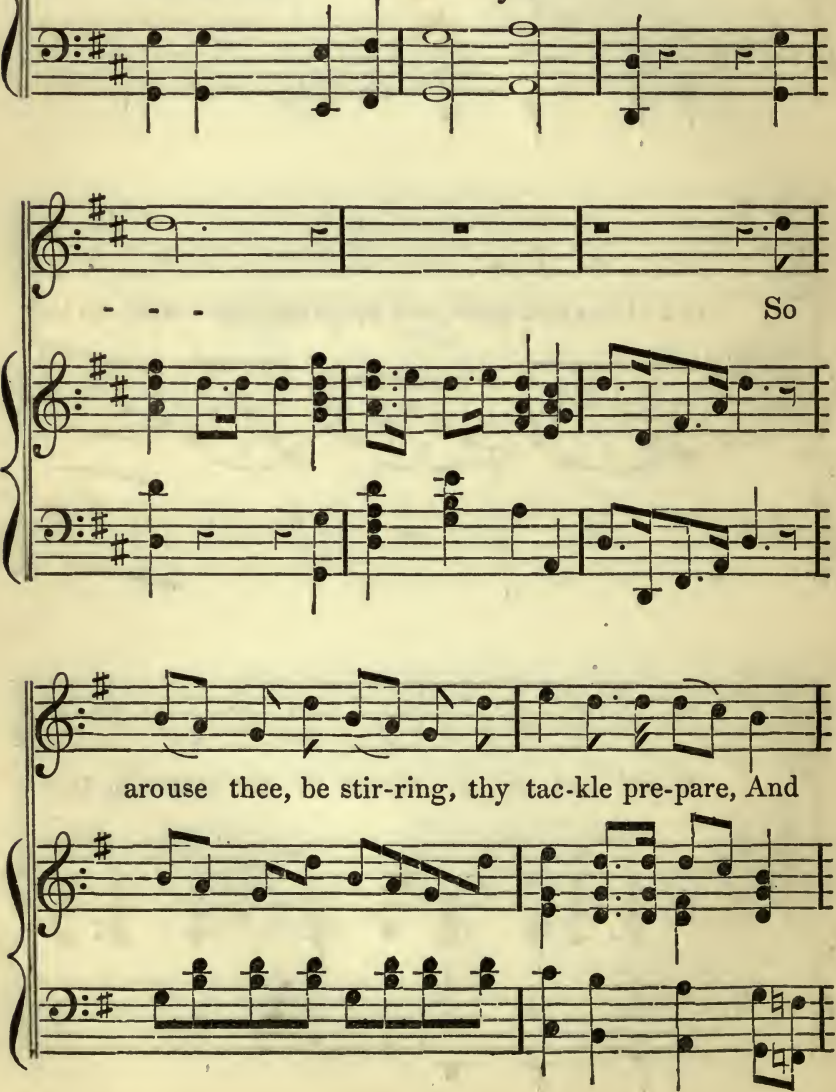


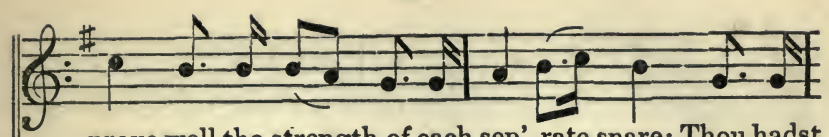
prove well the strength of each sep'-rate snare; Thou hadst

\{
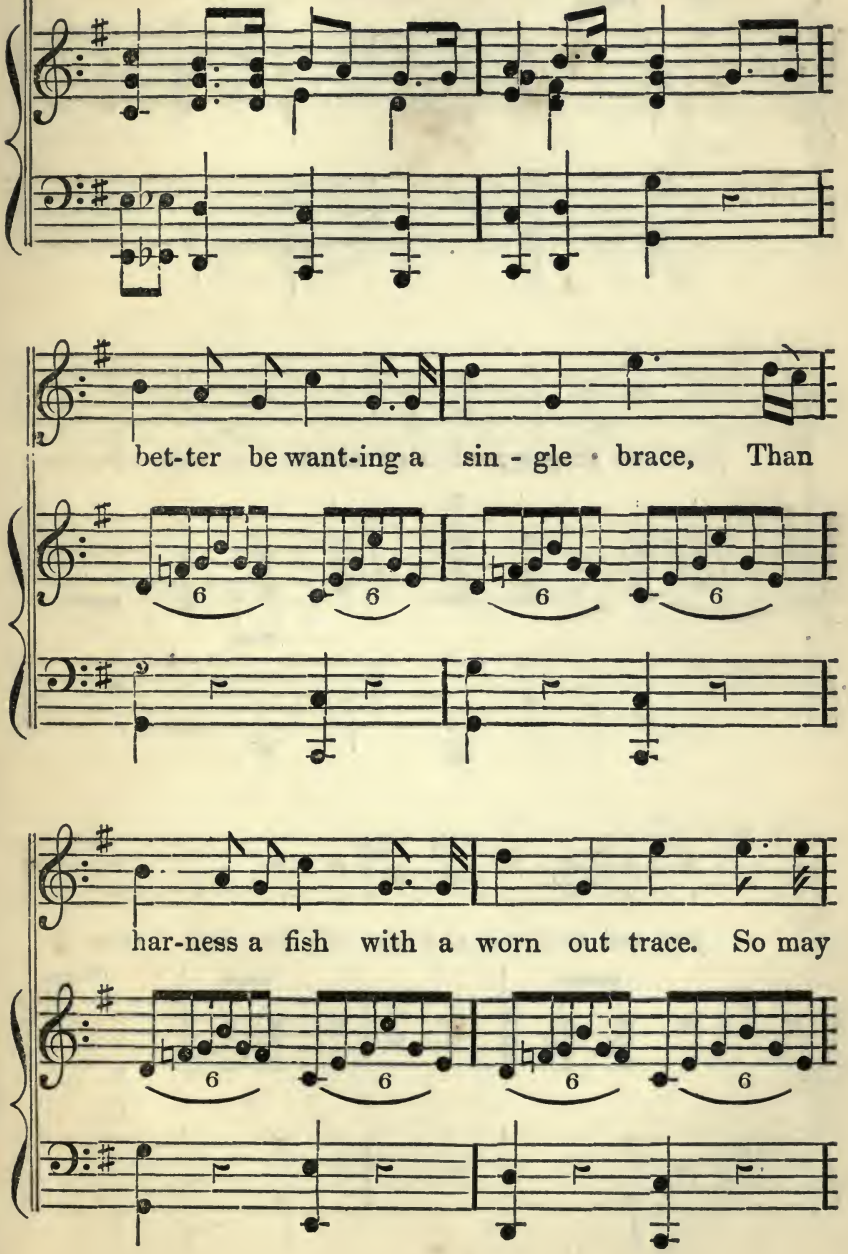

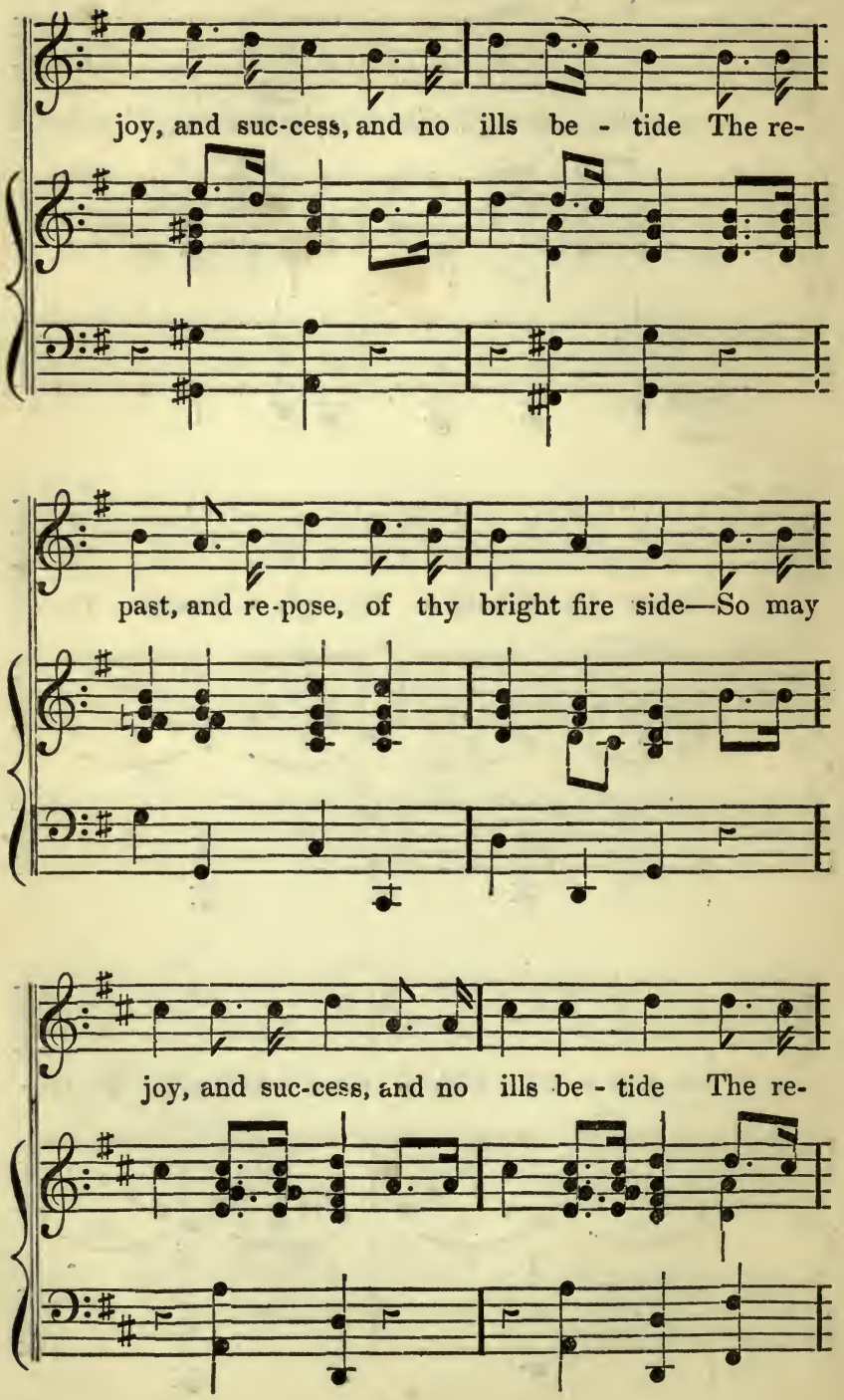
23
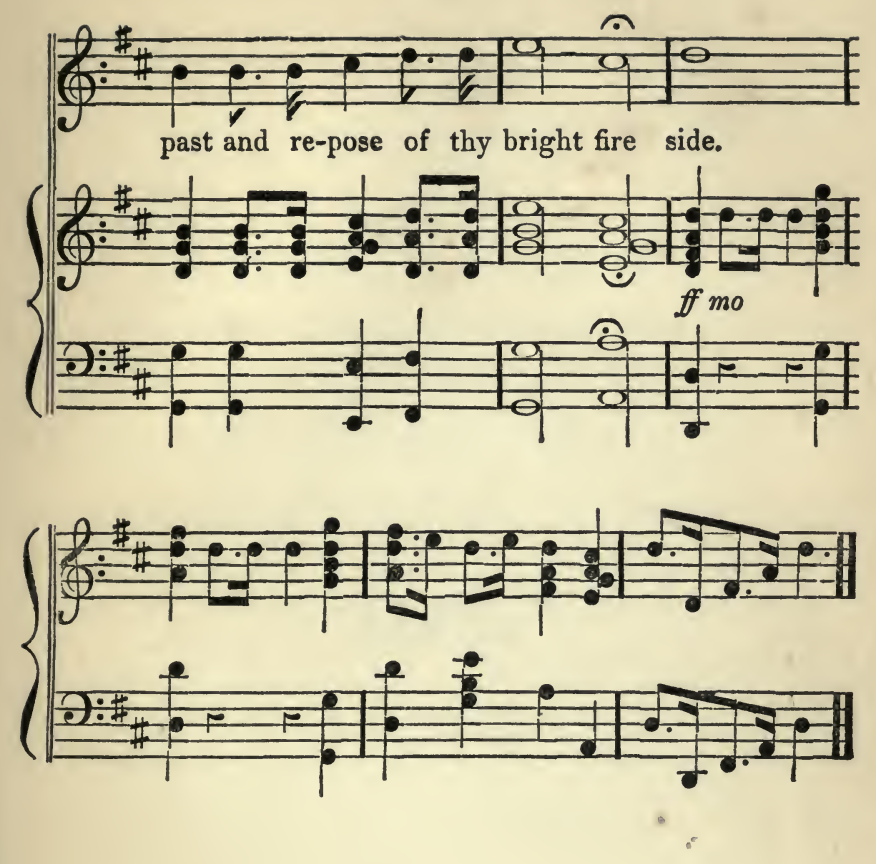

APRIL.

c 



\section{Aprit.}

Now does frail April come peeping 'neath her clouds, bursting with promises that seldom are fulfilled; she sporteth with our humour, and seems, as 'twere, to laugh at the temptation oft put forth; thus will she lure the haughty dame to wander in serenity and sunshine, when on a sudden, far removed from home, the o'ercharged vapour of some lurking mist, will jeering drive the angered wanderer back-as if in mockery of her conceit.

This touches worldly life; - those who must dress, appear in the last costume, and keep the house, if fashion's not abroad,-while those who joy not as we do, seek shelter from the shower, and back return to home, thinking the seasons altered every year. Poor mortals!
c 2 
that live only for themselves, and so exist in ignorance of our wholesome lives.

How different with us! the very spite that seems to thwart her pleasure, gives us new life : each shower calling to existence many thousand beings, that furnish the Angler's observations.

The Flies have now more colour, are stronger on the wing, and, from their daintiness, more eagerly sought by the Trout, than last month. It would not, however, be prudent to relinquish yet the March flies; for unless a very warm sun should look out for an hour or two, they lie dormant until the middle or near the end of the month. In the evening, if even the latter end of March proved warm, I would try the Stone Fly; its light wing is frequently attractive, - the more especially as it comes in pleasing contrast with the monotonous March Brown, Red Fly, or Cockwing. The first change I would make in April, on a fine day, would be to use the Golden Dun Midge; it might be 
tried, and successfully, on almost all streams, until the end of May.

I have been told of a very excellent Angler in Berkshire, who never changed his flies throughout the season, using a small Grey and Black Palmer, and most successful he has always been. This is all very well for a gentleman who has every day at his command, a stream at hand, and a selection of any hour he pleases; but for him who journeys some forty or fifty miles, can steal but a day or two once in a month, and wishes moreover to improve his skill, and knowledge of the Art, the precept is a bad one, and he would frequently return with an empty basket-his time and money ill spent. The Sand Fly is perhaps the most generally successful that you can select, as it does not wait for weather or season after March, and is always highly esteemed by the Trout. In the absence of sport by the above, our friends Grey and Black Palmer may always be had recourse to, and frequently with success, 
on all waters-I might perhaps say, in all countries.

I worship April; it is the harbinger of all the joy we are so constantly looking forward to: how proudly is the brow of nature lifted to receive its bridal May! How gaily is its head bedecked with every fragrant flower, that now buds forth, and promises to bloom! I like variety, so give me April, and ever may we praise it, as, with your attention, I will now attempt. 


\section{ARIA.}

Sweet April, come, I love thy show'rs, Scented with early bloom and flow'rs, Alternate gloom, and sunshine bright, Morning of hope, and life's delight ; Joyous we tread thy spangled lawn When April days begin to dawn, And grateful oft we praise that Pow'r Who gave the sunshine and the show'r.

Let those who joy not in our sport, Go waste their time in Fashion's court, Wed foul device, not Nature pure,For Fashion, Nature can't endure : Long toilsome nights and dull spent days Are hours that wait on courtiers' ways ; We bask in joys not framed by art, Own but one monarch-that's the heart. 



\section{APRIL.}
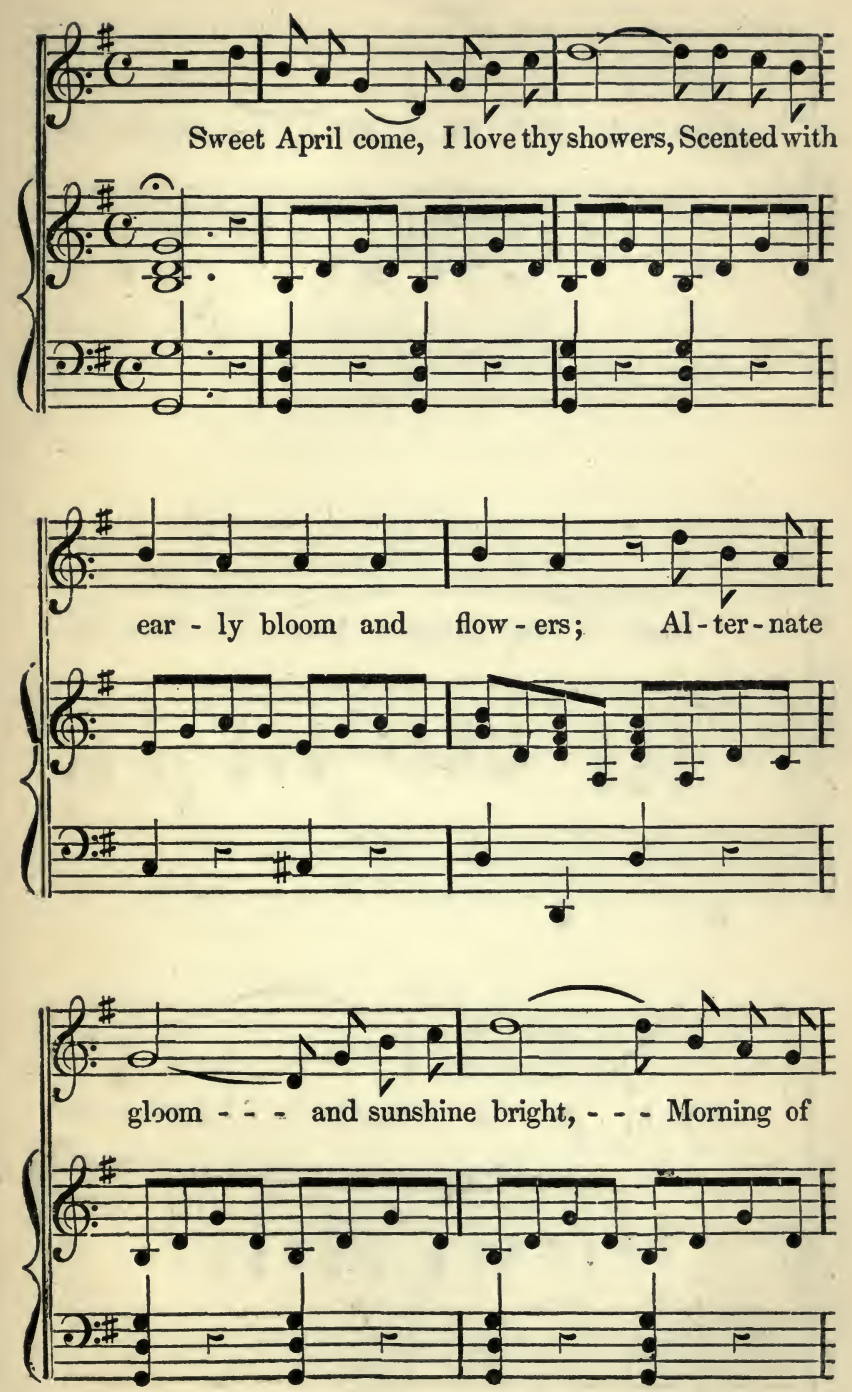

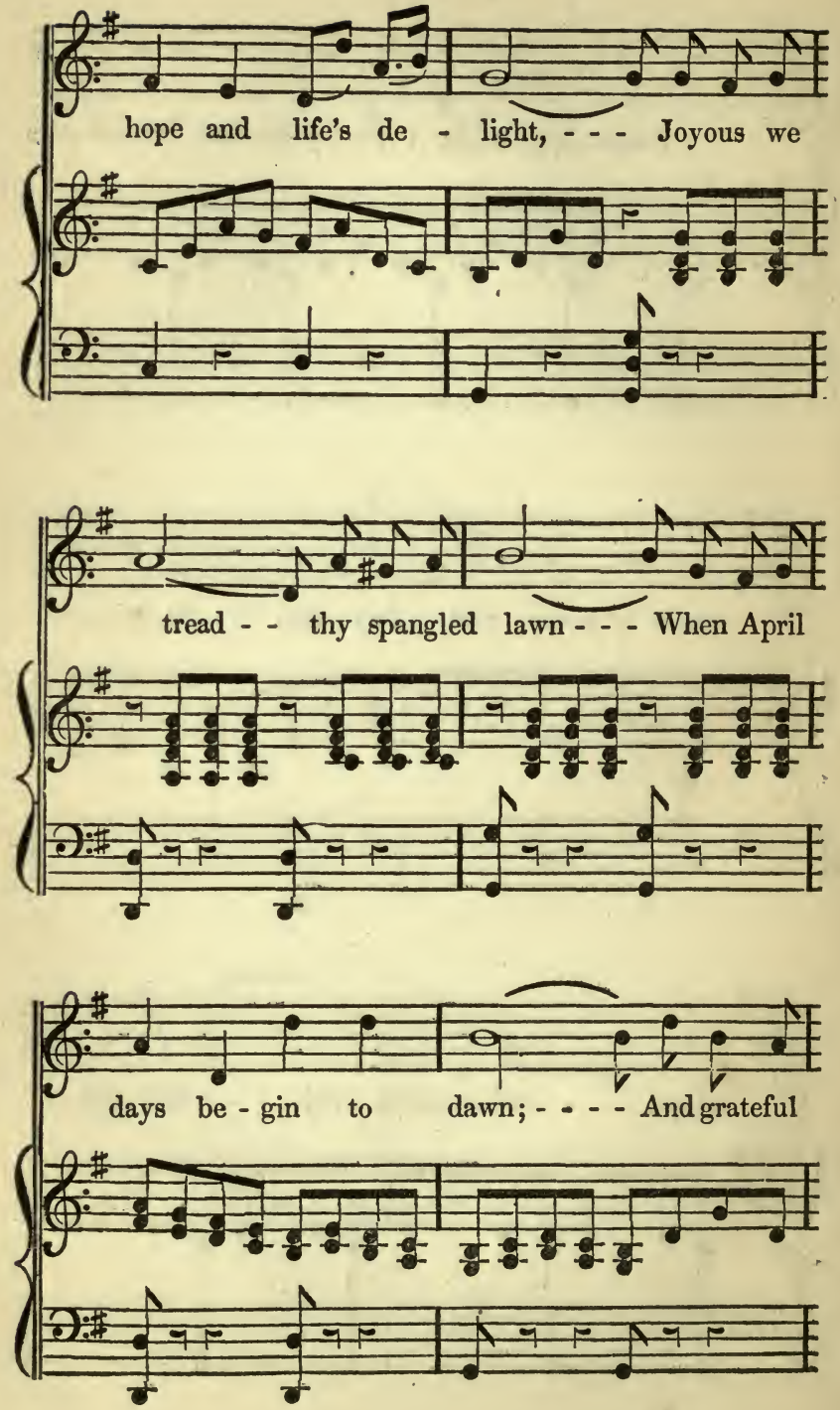

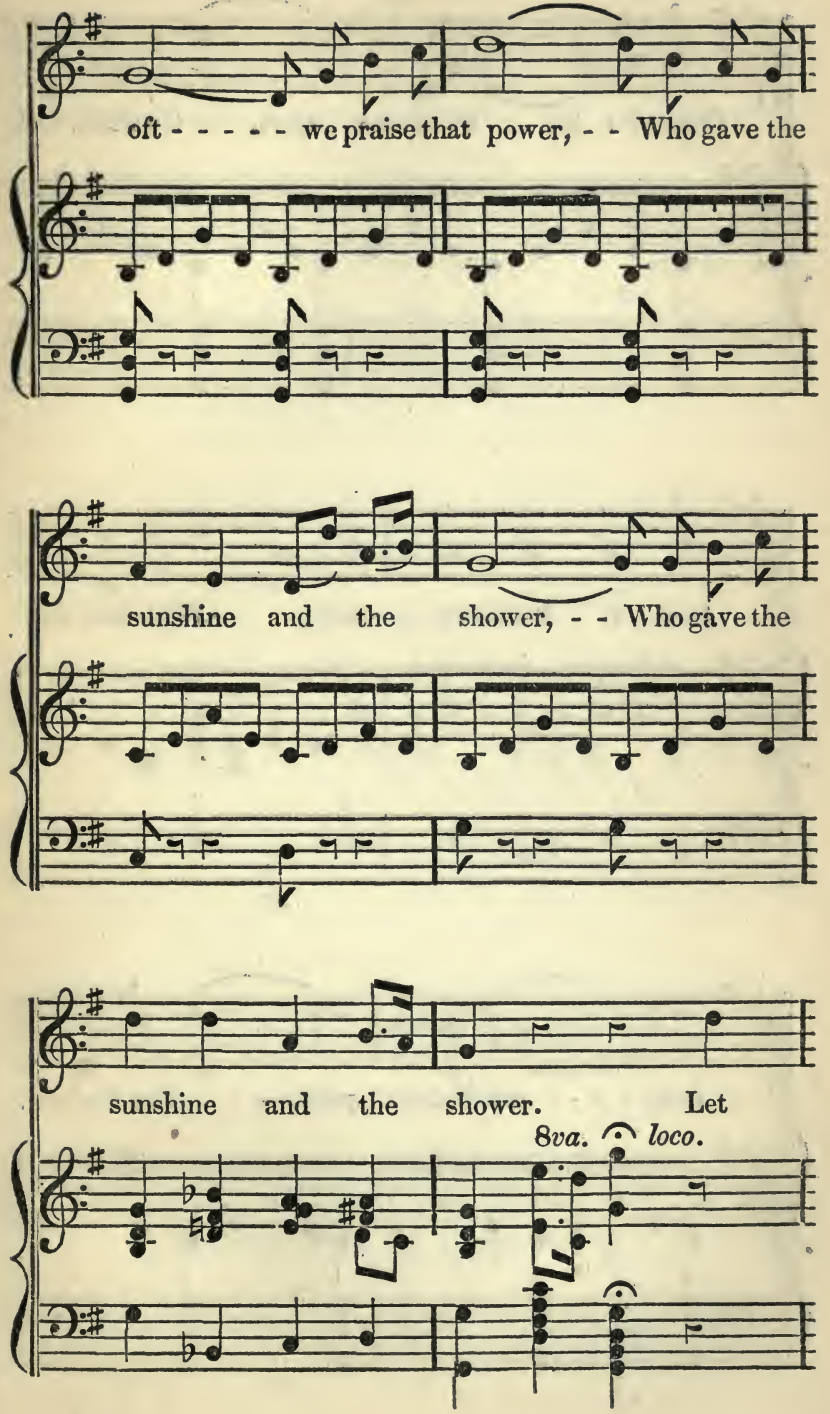
36
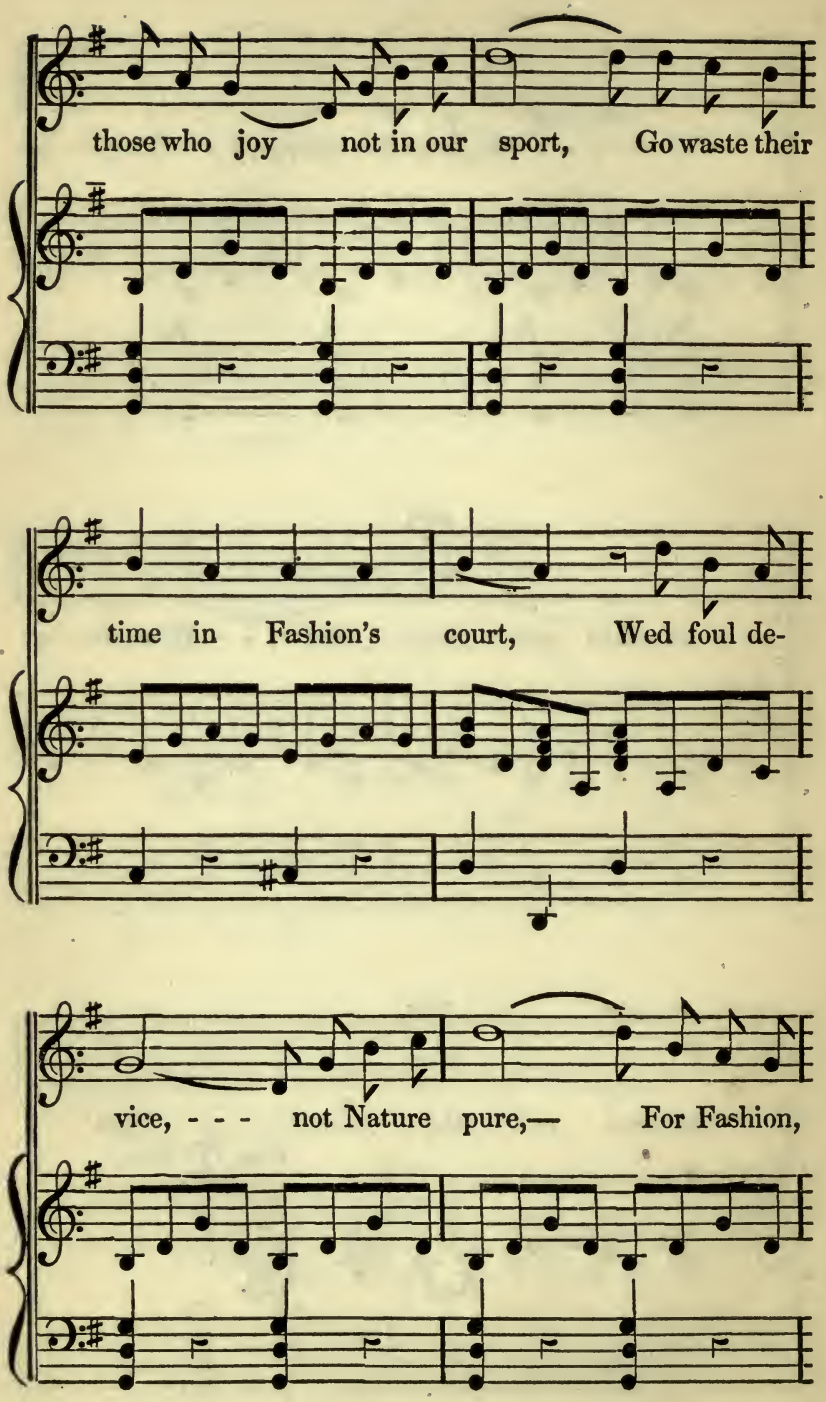

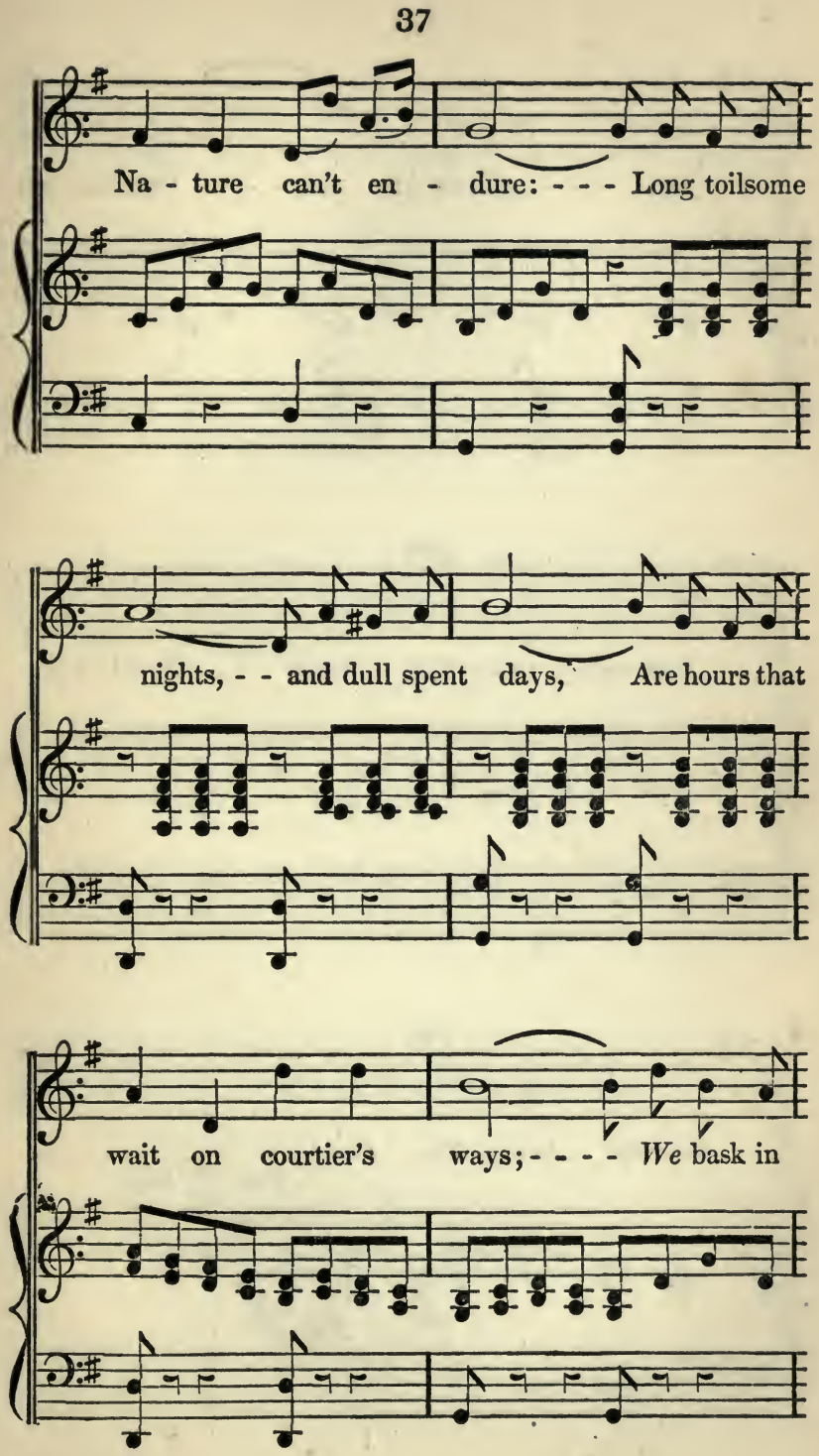
38
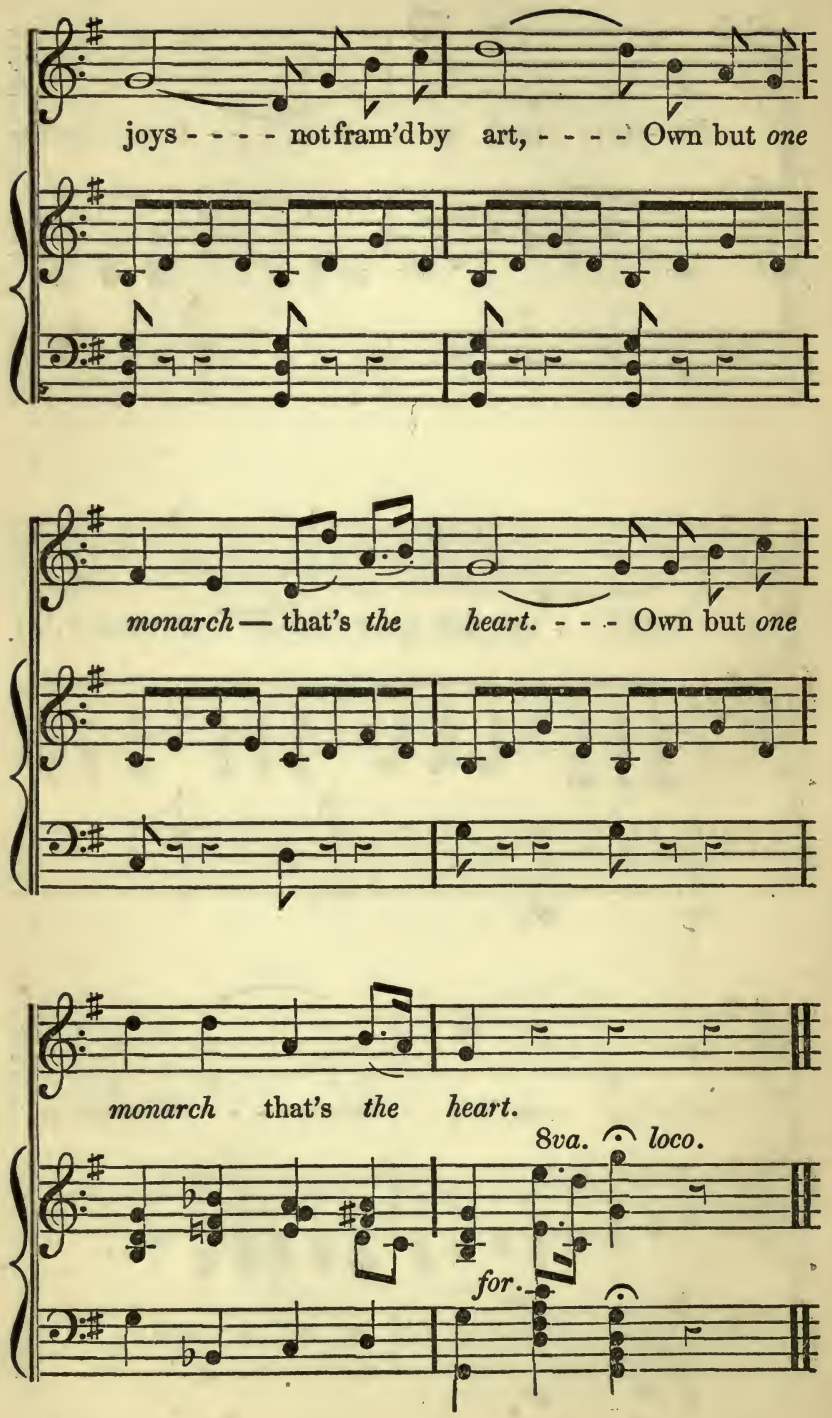
MAY. 



\section{\&tlap.}

How shall I introduce you to this heavenly month-bright May, the incentive of all Poetry, of Painting, and of Music? Each dormant energy is now called forth, and bid to welcome e'en the name of May. The husbandman begins his song, the Angler casts aside his warmer clothing, the Poet meditates new lays, the Painter sets forth upon his voyage of discovery, the Musician is inspired by vocal woodlands, and the World indeed is busy giving cheerful welcome to this harbinger of heaven on earth. Now would I sketch my favourite haunts of last spring's rambles: the shady lane, the mill upon the brook, the busy hive that warned my idle curiosity, the rising plant, young avenue of trees, all that I had 
marked progressing like the spring, and each approaching to perfection, myself alone on the decline, their youth contrasting my increasing age.

What in nature can surpass the golden blush and purple-tinted hue of an evening in May; the hawthorn-scented lawn, and lily-clustered path? To wander gently through some quiet hamlet near the brook, and then to observe a flickering light, darkly illumine some poor humble shop, where all the articles that want, or village pride can wish, are in their best allurements set forth, a motley group. Here let me pause, and place this modest, unambitious house in contrast with our town depôt. Can I with patience view such artificial life, and gaze as coolly on the real? Yet by these means the world wags on -the industrious are employed, the ingenious rewarded, the nation's commerce fed, and life whirls on in heedless mazy round, all fancying they are happy in their sphere, but none conscious save those who see and prove its 
opposite enjoyment. Now the inquiring gaze of some admiring boy, who, with his eyes and mouth wide open, wishes he had such a rod as mine-how he would catch the fish! An honest Peasant smoking at his door, enjoying the release from labour, hails me with, "What sport, Sir ?" and when he hears 'tis good, then how the gaze of every urchin brightens, watching my path as far as they can see, and almost fancying they possess the envied trout. At last, on reaching my head quarters, I receive my hostess's curtsey, with, "I hope, Sir, you have enjoyed yourself, and that your sport has been sufficient to induce a longer stay than first intended; -what would you like for supper, Sir? -we will keep your Trout cool in the cellar," \&c. \&c. All this to encourage my prolonged visit. Mine hostess, however, is a very good and obliging woman; and we all have a right to try and mend our fortunes.

Of late, May has puzzled the best Anglers; the weather has been unsteady, and conse- 
quently the Fly uncertain. I never knew this month so fine, that it authorized, immediately on its appearance, the discarding every April insect; unless towards evening, when I would use the Coachman, and most frequently with success. The Governor is also excellent until the May Fly rises; the Black Gnat is good in the middle of the day, but in the evening, the Coachman before all others. The above are, in my opinion, all that are necessary in this month, with the exception of the May Fly, and that must be most admirably made before you can hope for success. Half a dozen Flies are better than a thousand. But then it is so pleasant to look over one's hooks, to tie them afresh, and then to fancy a Fly for the next day ; the liking most probably confined entirely to ourselves. It is a foolish fastidiousness; and we frequently think (even after the most acute observations) that our selection is bad, because the fish do not rise at it as rapidly as we could wish. The fact is, the very slightest variation of temperature is 
detected by them, which to us is quite imperceptible, and they withstand temptation till it has passed. Who now is the philosopher, the Trout, or the Man, that checks his appetite at pleasure? Hold not in contempt, then, the creature which hath life, endowed with what we call instinct. Grant it so, if reason is a greater gift, then is there less excuse for our infringing upon those laws, which gave us suiting instinct, adding reason for its guide. Leave the dull plain of custom. Quit gaiety's unthinking, feverish path, and tell thy young friends the Fisherman's delights, his overflowing, grateful heart, and his unceasing thanks for this sweet essence of the year. 
SONG.

Fair May, how shall I greet

Thy balmy breath, and flow'ry feet?

What pray'r impart?

How my thoughts glow to see

Nature so bright and free,-

Grateful my heart.

The world is alive with joy;

No care, no cold alloy

E'er sullies thee.

One bright beam greets thy birth,

Pure child of Heav'n on Earth, All hail with glee.

No being exalts thee more, None greater blessings pour On thy sweet hours,

Than he who seeks the stream, Free as thy happy dream;

Thine, are his bow'rs. 

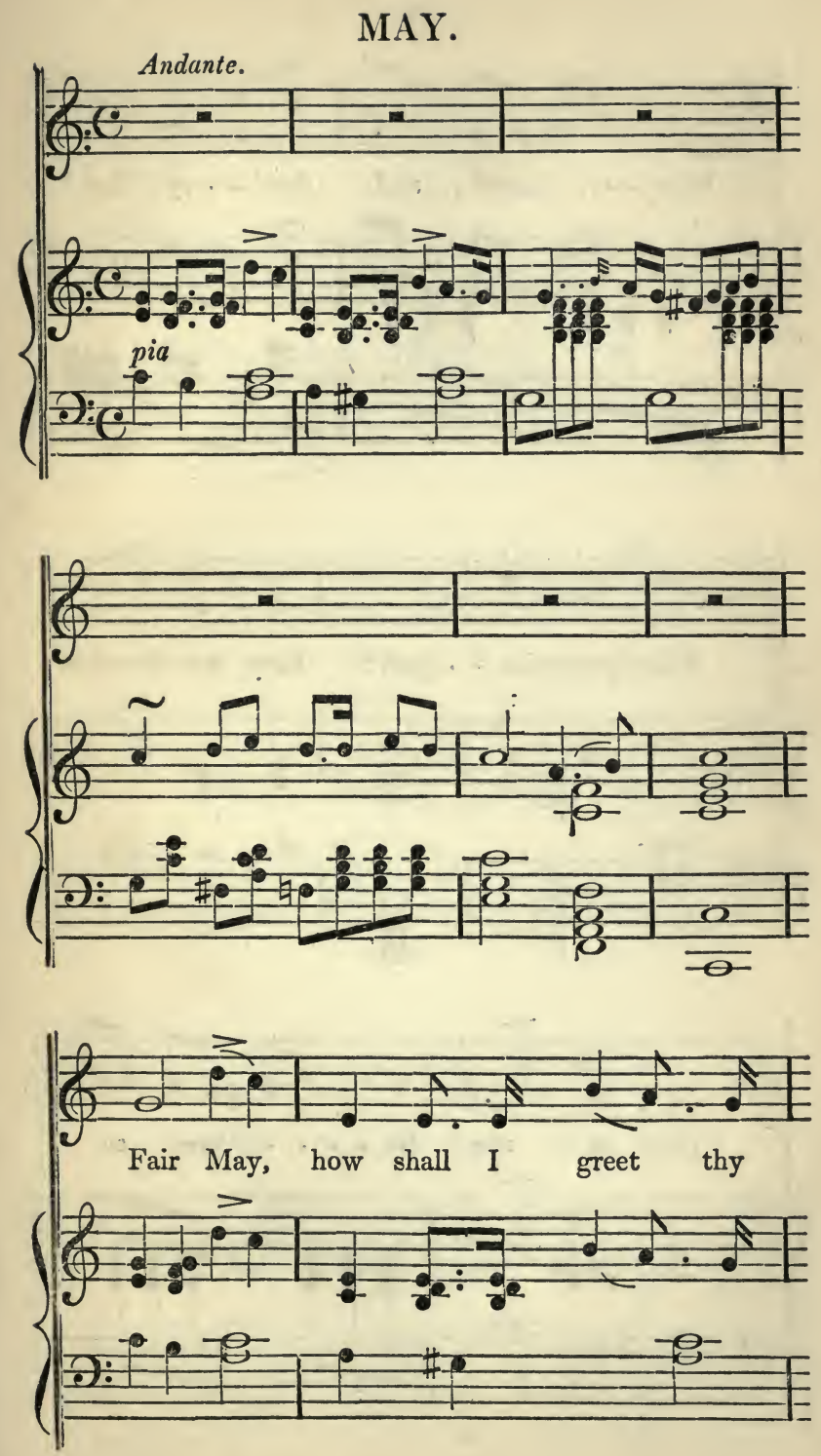
48
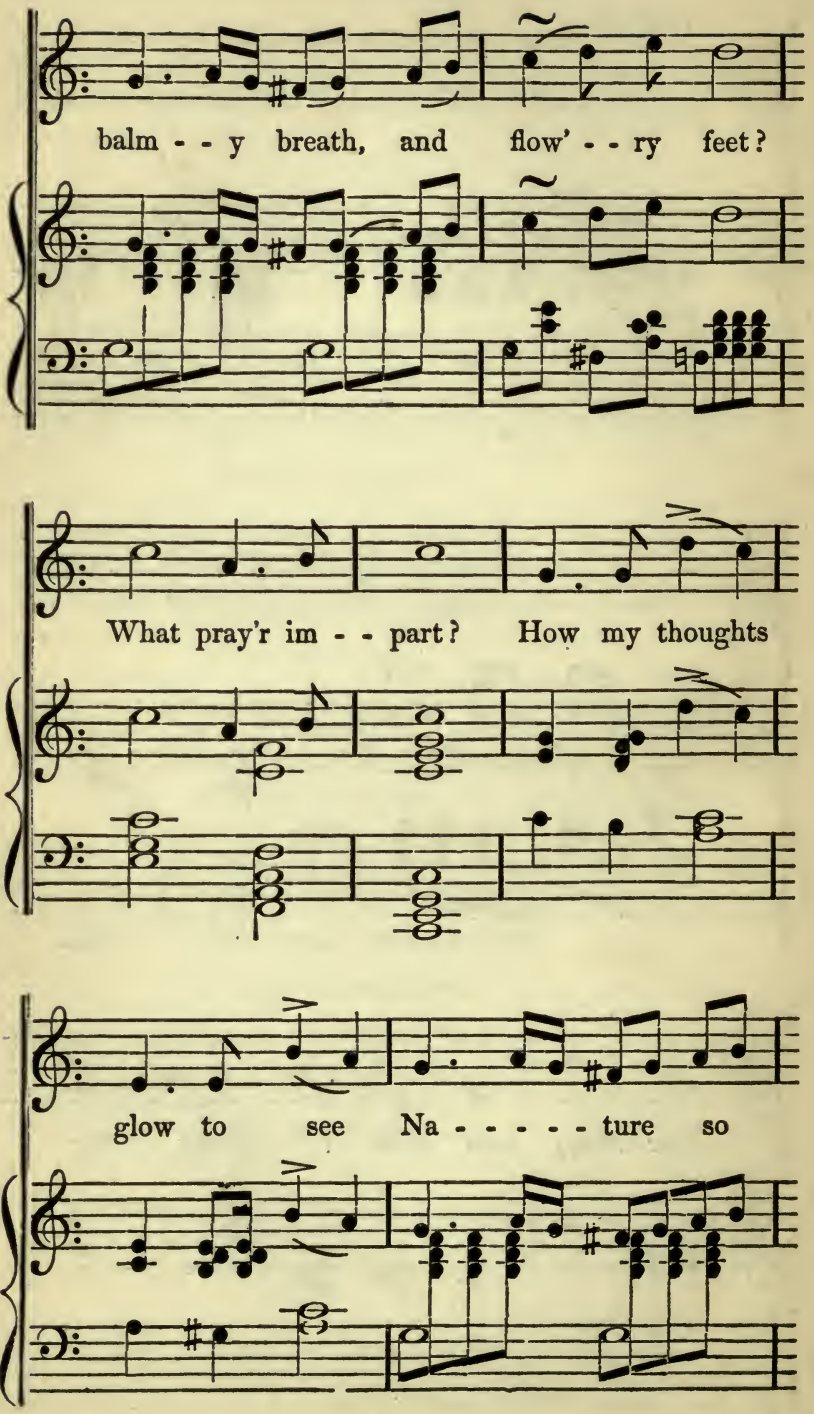

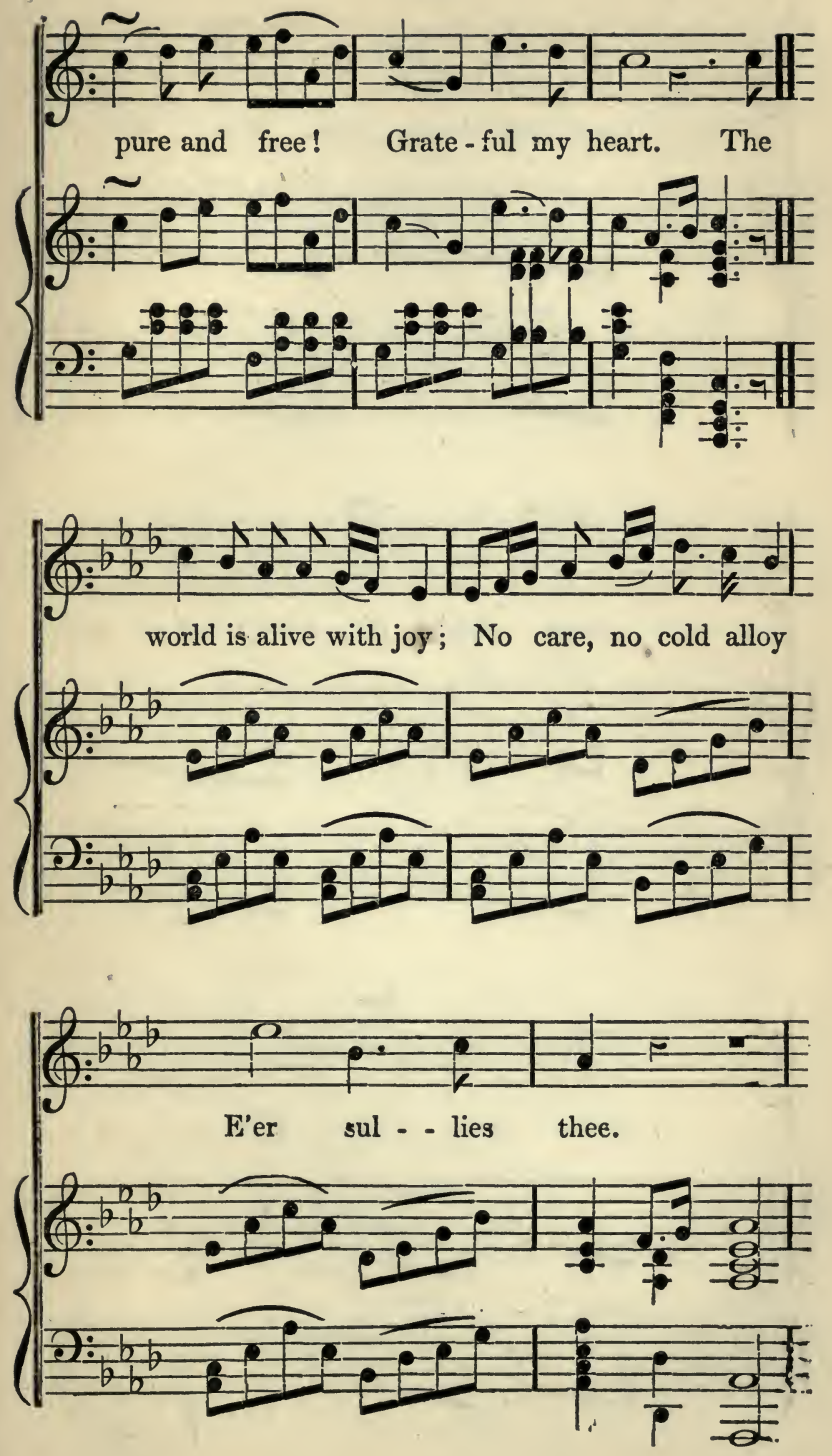
50
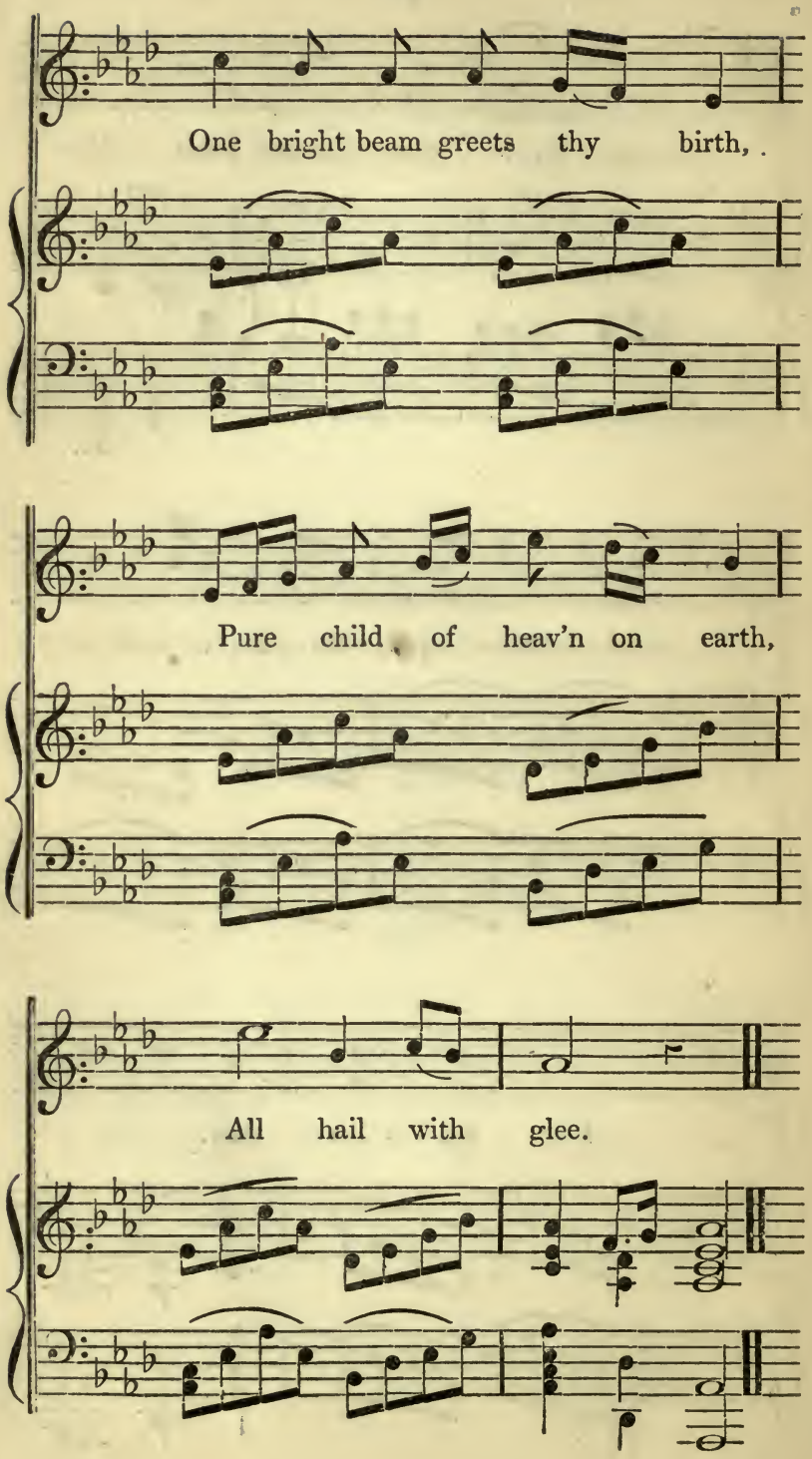

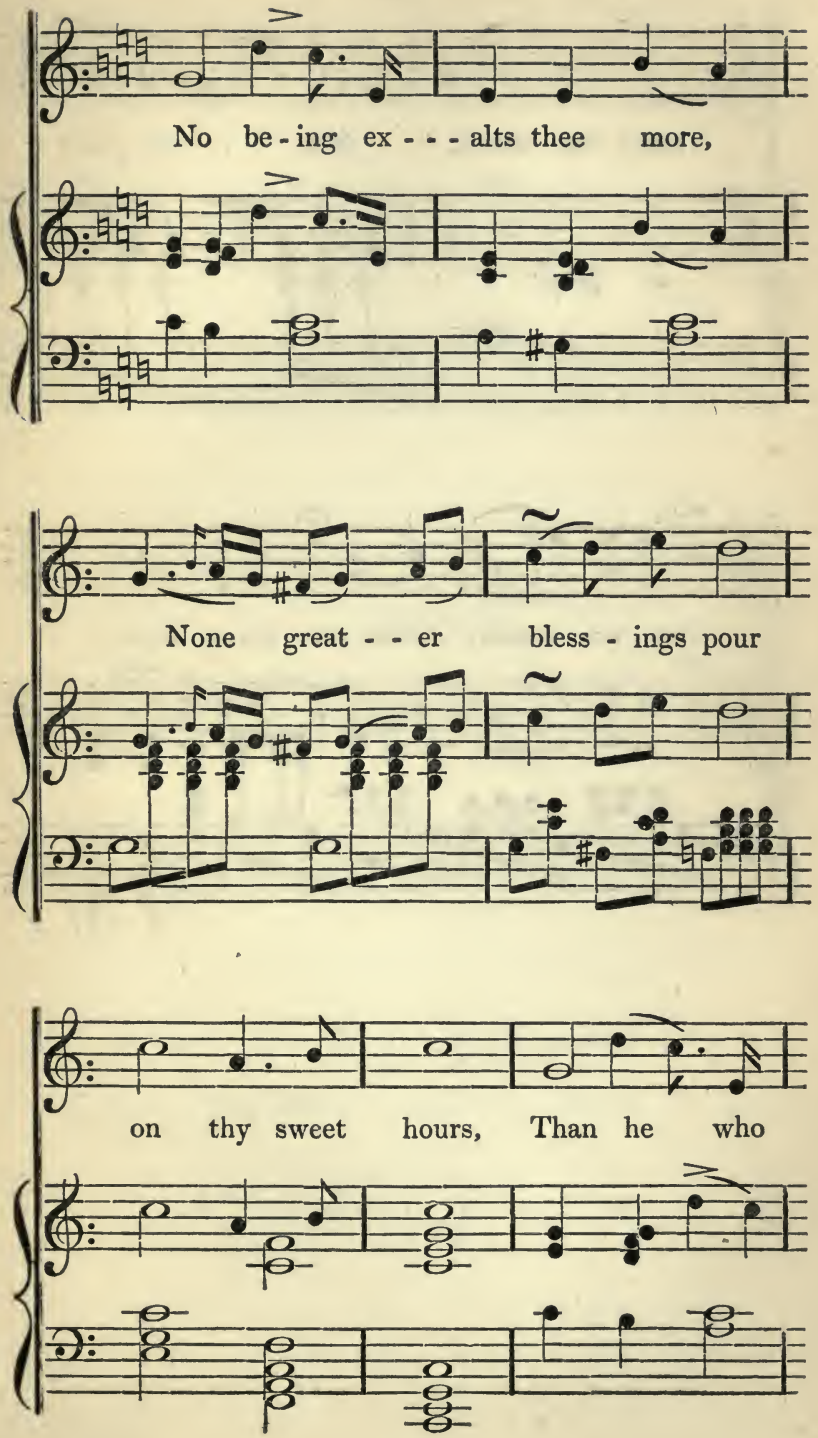
52
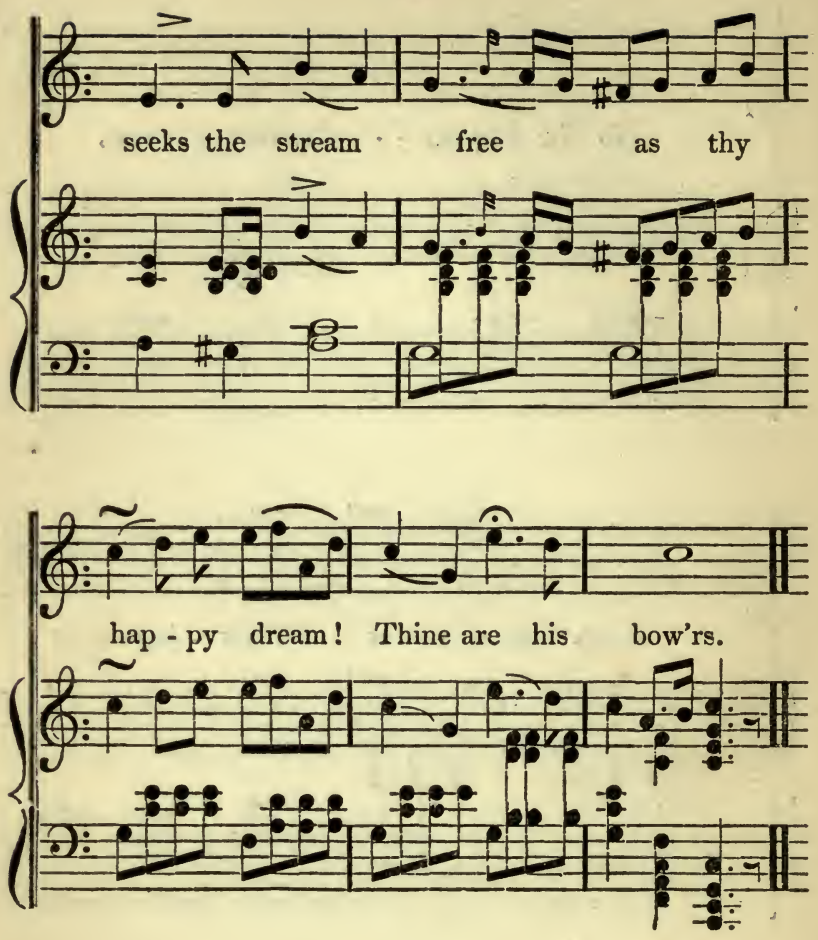


\section{JUNE.}





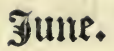

MaY has passed by, but not from my memory. I see the parent, in its infant June, and all Nature smiles to have an offspring so unclouded. The lightning leaves its vapour to catch a glimpse of thee; the thunder roars in joy for the event; mankind looks glad upon the happy time that ushers thee to visit this far-envied land.

My young plants have reached perfection, and bloom around my window, where I first gave them the opportunity of life. How smiles my rose; my hyacinth how gay; how proudly does its plumage wave in passing zephyrs, and the language of sweet flowers join in its tide of song! This month I will devote to Drawing, Music, and Angling - of all, still my most 
favourite pursuit. The grey-eyed morning sees me fishing; the mid-day with my pencil; the setting sun doth linger to behold my sport again, then rests while I employ my evening in song. Oh! what a life is this, that can enjoy the infant breath of morn, retain the landscape passed (in reality, perhaps for ever) from his view, and praise in bold chords, and most harmonious sounds, the events of such a day.

A circumstance occurred to me in this month that would have been gratifying to any Angler. I was on a stream in Hampshire, where midway stands (surrounded by a few houses) a most unpretending village inn, so trifling, that I do not think the wealth of the whole colony would purchase a respectable farm. At this little place of entertainment $I$ was in the habit on a very hot day to get a glass of home-brewed ale, which they vended most excellent. My sport was not so good as usual; thunder was abroad, and then the fish lie scared at the bottom, and will not notice any thing that 
passes, though they die of hunger. Notwithstanding, I had contrived in the early part of the day to take two brace; three of the fish were very fine. I called at this little inn about noon, very fagged, very hot, and much disappointed at not having caught more on apparently so fine a day. I feared it was thunder, and a short time proved my anticipation to be correct. The sky blackened, and the storm, like a mighty giant, came growling o'er the earth, threatening all nature with impending ruin. The birds were silent as the night; the affrighted cattle hastened to each tree, or shed, that seemed to offer shelter; the shepherd's dog hung down his tail, and, with a head bent low, crouched to his well known master; the vivid lightning flashed, and seemed as 'twere to scan each secret haunt of those that vainly hoped to escape its vigilance; the rain, as it advanced, in torrents pour'd; the river foamed with fear, and all the horrors of its awful majesty commingled to impress imperious man with D 3 
his vain boasting, and comparative insignificance.

As it happened, though my produce was comparatively small, it proved of far more value than when I frequently boasted more than I could conveniently carry. The storm had driven me into the stone kitchen of my rural hotel, and I observed a very decently dressed woman seated in the hollow bench, with two children, their little heads hid in her lap. I imagined them very happy, and observed to mine hostess, how delightful it was to find the peasant so lodged, and resting in a secure and peaceful abode,-how happy they must feel.

"Ah," she replied, "they are resting, to be sure, Sir, yet are any thing but happy; they have journeyed many miles this hot day, and are on their way to Portsmouth, where the father of those babes is hourly expected to arrive. It appears he has been shipwrecked, and returning in another vessel; they are without money, and I have none to give them, and they 
have not tasted food since yesterday; and you know, Sir, we are too poor to give them relief."

The woman sobbed again as she told me this sad tale. Imagine my delight, when I thought of the trout in my basket. Turning up my sleeves, I became cook, scaled a brace, prepared them for the fire, and in a short time we were all seated together over our substantial and most dainty dinner, to the astonishment of the mother, and the little souls that accompanied her. It would have made a heart of stone ache to see how they devoured the meal. On lifting their little heads to look at the stranger, I was surprised at their beauty; their eyes were full of tears, yet they were too weak to cry, as though all the energies of the body had been exhausted. The sight altogether overpowered me, and I did not speak till the repast was nearly ended. How the poor mother lauded then the Angler; how different a gentleman from the haughty Overseer, the husband's Captain, their Landlord, \&c. \&c.; indeed, she could not find 
sufficient blessings to pour upon my head. They never dined more happily, I never felt such joy. The remaining brace, and a few shillings I had fortunately with me, sent them smiling on their route; and it is strangely true, that ever since I have been more successful on that part of the stream than any other, as if in remembrance of the happy circumstance I have just described.

The best rules laid down for classing your Flies during each month, have failed most frequently to produce successful results. I have often observed, that which is in season passes uninterrupted, when the very opposite in colour and size will immediately be seized: this circumstance I do not remember to have been accounted for in any work which I have read, but really think, if the fish are on the feed, they will take any seasonable Fly that first offers itself. They, like us, are only dainty when not hungry. The insect most likely to be successful during the whole of June, and probably the next month too, is the Alder Fly; the eggs are 
deposited on the leaves of trees and bushes, which are near, or overhang the water. When once the Trout has seen it in existence, it almost constantly watches under the bushes for its production, for dropping immediately on its birth into the water, it is readily seized before it can recover to fly. The Angler should very carefully drop his imitation as much under the opposite bank as possible, and not draw it away too quickly, but let it sink about an inch under water; indeed, it is a mistaken idea altogether to suppose the art consists alone in throwing; the skill is shown in its management when on the water, by letting it sink, and drawing or jerking it slightly, and very slowly. The largest fish always seize their prey under water; if your throws are frequent, you might as well wade the stream, the water becomes so much disturbed. The Green Drake, Black Drake, and all of that tribe are favourites during June; much, however, depends on the weather for their existence, and then they do not remain 
long. For myself, I would be quite content with two Flies, - the Alder, and my favourite Coachman in the evening - the evening after all for my success.

But now I see the damps are rising; the rook doth homeward wing his weary flight; the anxious mother beckons to her child, who quits the rural game for rest; the cattle low, and seek their weather-beaten shed; the feathered tribes forsake the silvery lake, and march in mimic order towards the barn; the watch dog barks at every distant sound, and twinkling lights come dancing through the shadowed leaves,- - the water bears reflection of the coming night, and now the laughing star of evening is up, as if sprung suddenly to existence : all warn me of the many fields and long dark lanes that I have yet to tread ere I reach home. My companions have no doubt retired from the stream. There is no appearance of a human being, except yon lazy shepherd, whistling, and leaning o'er the gate, and gazing on-he knows not what,-so I'll 
e'en wend my way and hasten to display my store. I fancy how my brother Anglers will be surprised, unless their chance has exceeded my own. What ambitious beings we are! No! $w e$ are not-it is an honourable emulation; and if one is more fortunate than the other, he does but jeer in jest, which but provokes his brother to use greater vigilance next day. Hailed at the door, I am ushered to the cheerful meal, which ended, I relate my story of the poor woman and her little ones, and find myself (as I anticipated) the only envied person in the company.

Now, then, to our evening custom : a strong voice, a clear conscience, and a grateful heart for the blessings of this day. 


\section{SONG.}

Our glasses fill'd, advance thy toast, and let us have it soon,

I'll give thee, honest Angler, then, this glorious month of June,

E viva, e viva, we join the merry tune.

Let lazy hounds go seek the shade, and nurse the sluggard's dream;

The stupid dolts, to sleep, while we go rambling by the stream.

-We seek not health in slothful ease, nor in the gilded hall,

Nor in the vicious court, nor in the mask or ball,

E viva, e viva, we like not mask or ball.

But, under bounteous heaven, do we pass our happy days,

Admiring Nature's various laws, and following in her ways ;

And now uncover'd, let us thank, in this right merry tune,

That gracious Pow'r, which sent on earth this glorious month of June,

E viva, e viva,- the Ruler of bright June. 


\section{JUNE.}
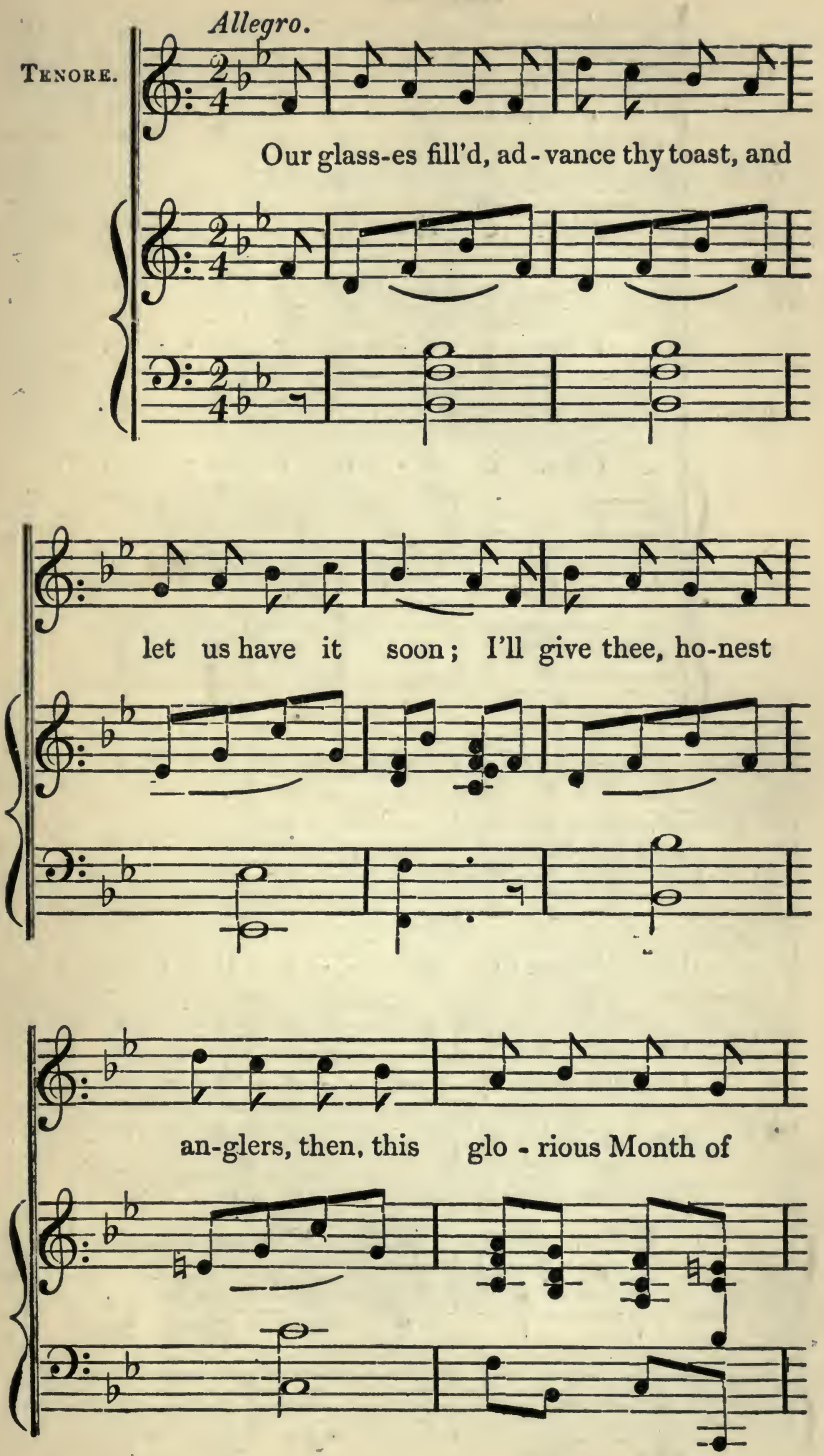


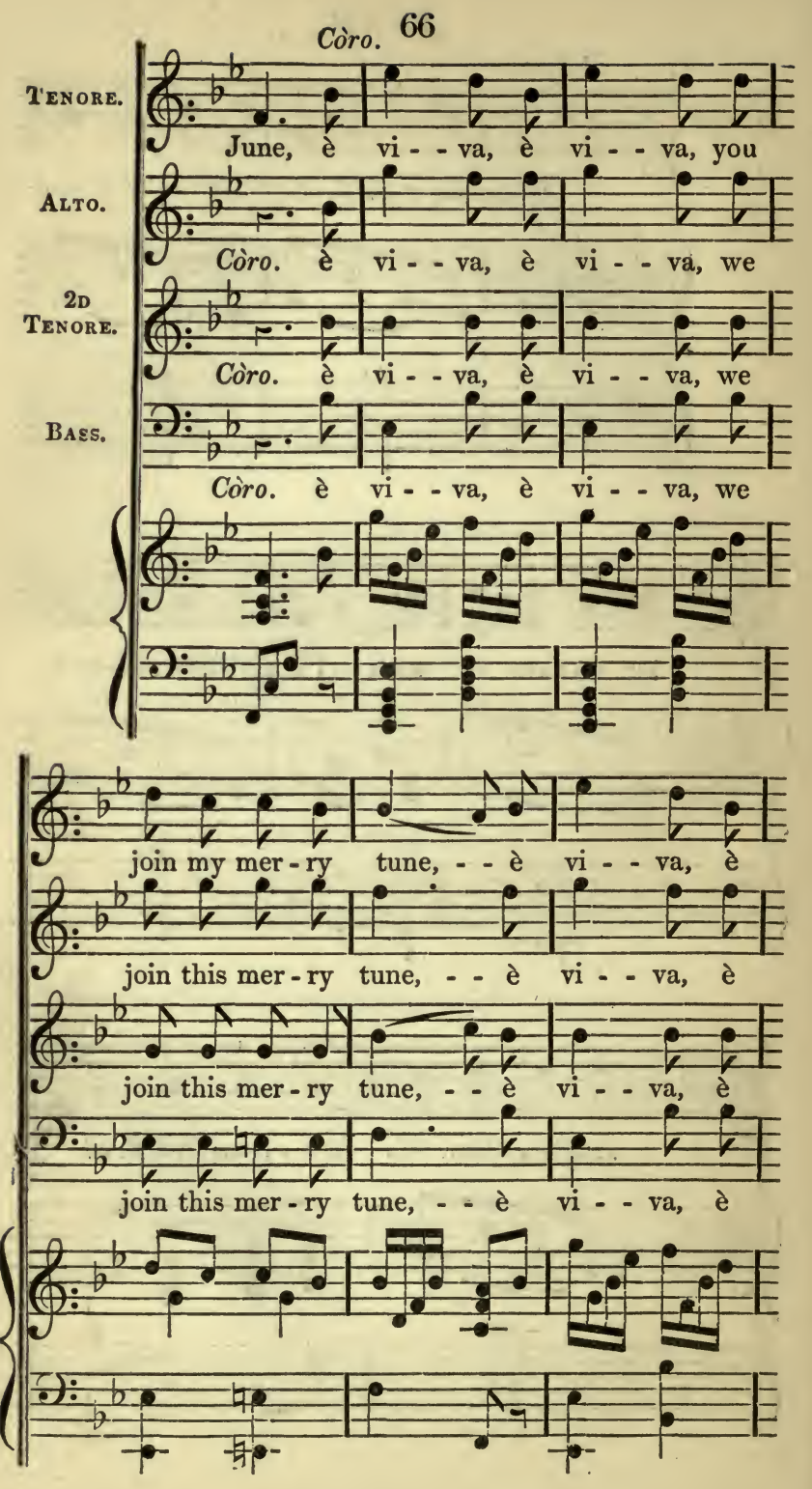



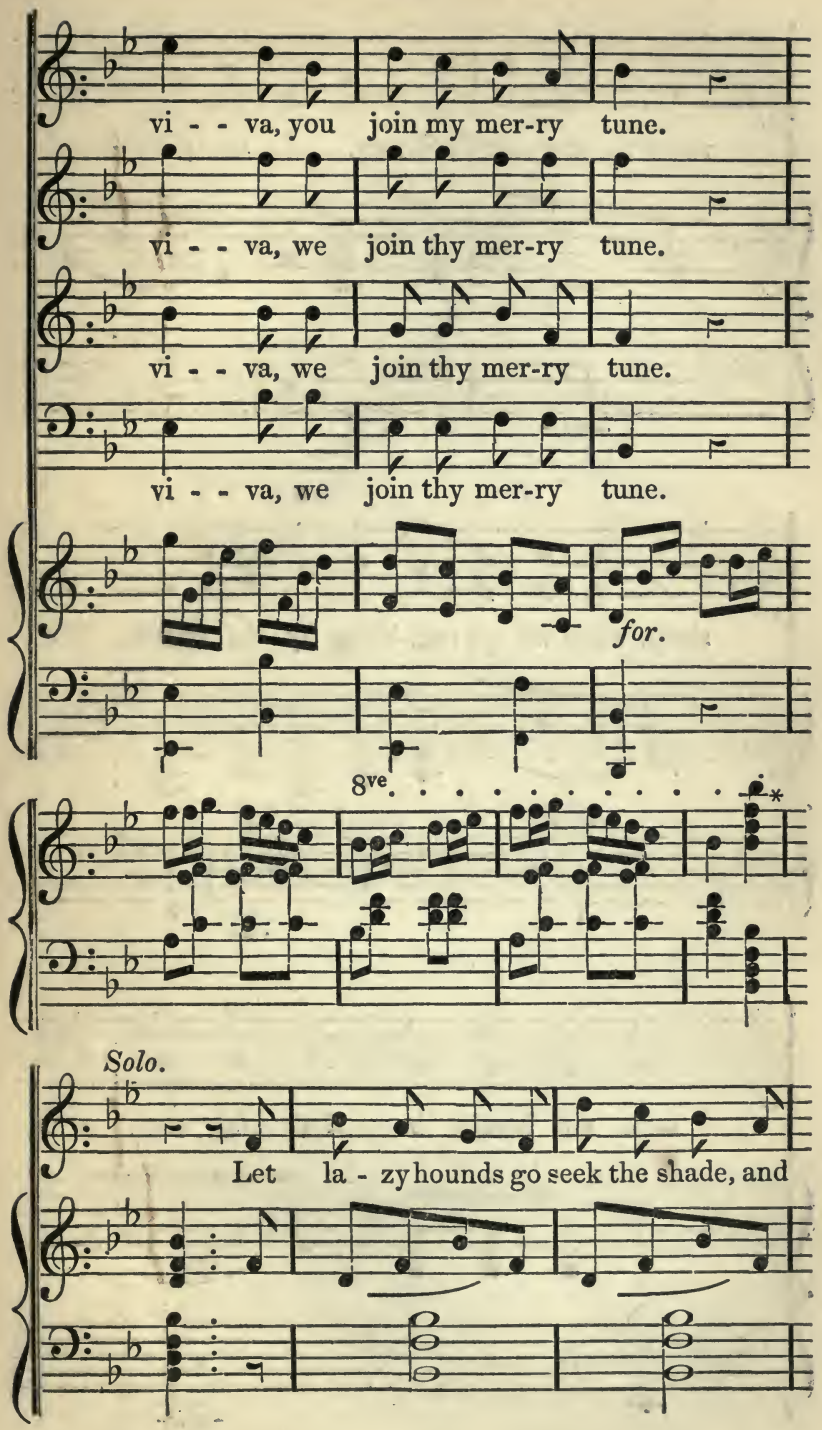

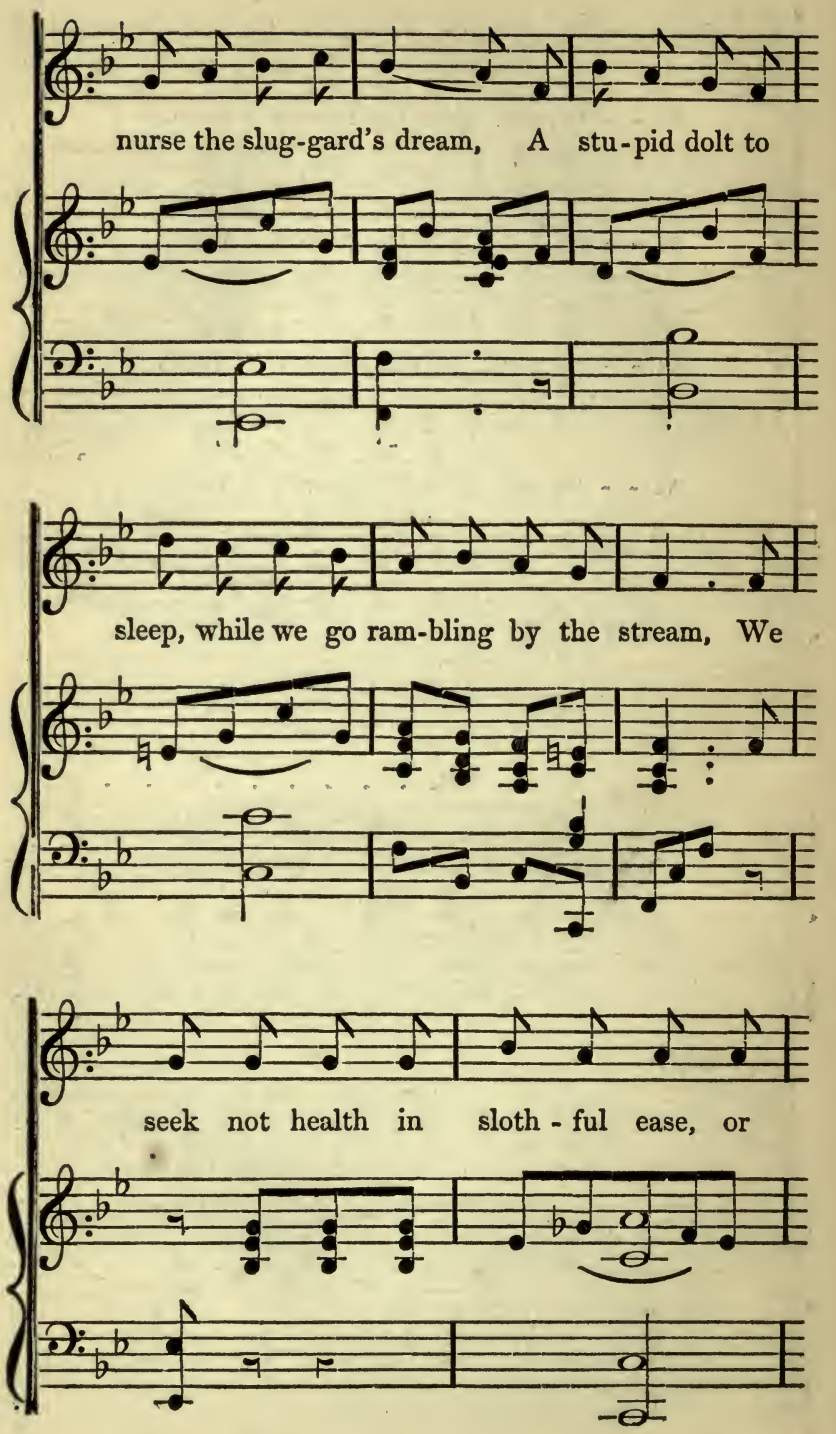

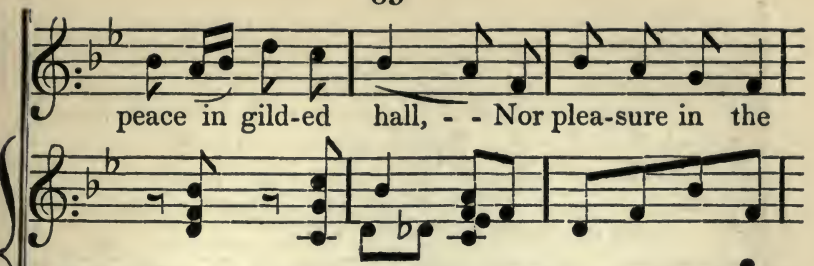

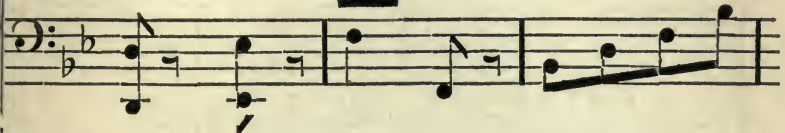

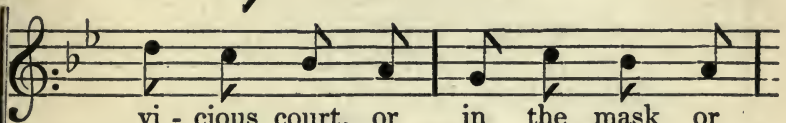
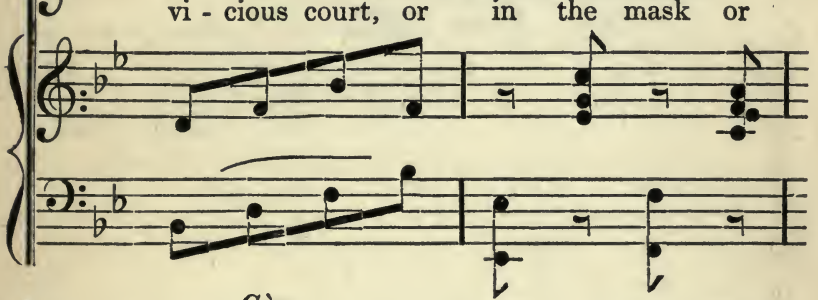

Còro.

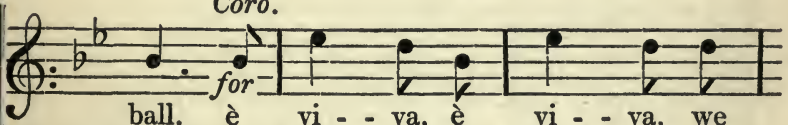

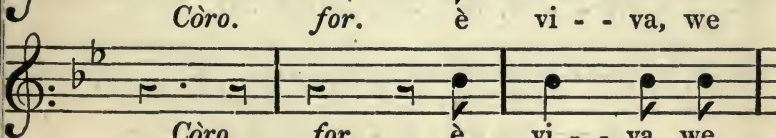

Corro. for.

Coro. for. è vi ... va, we

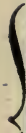

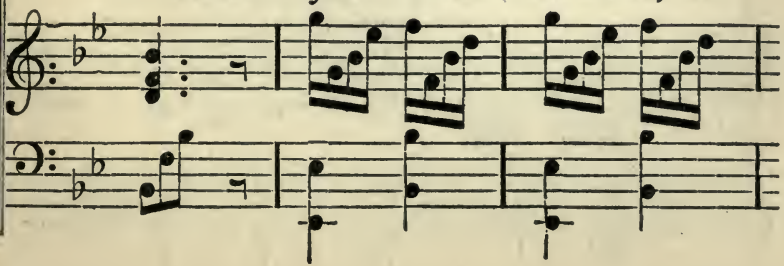


70
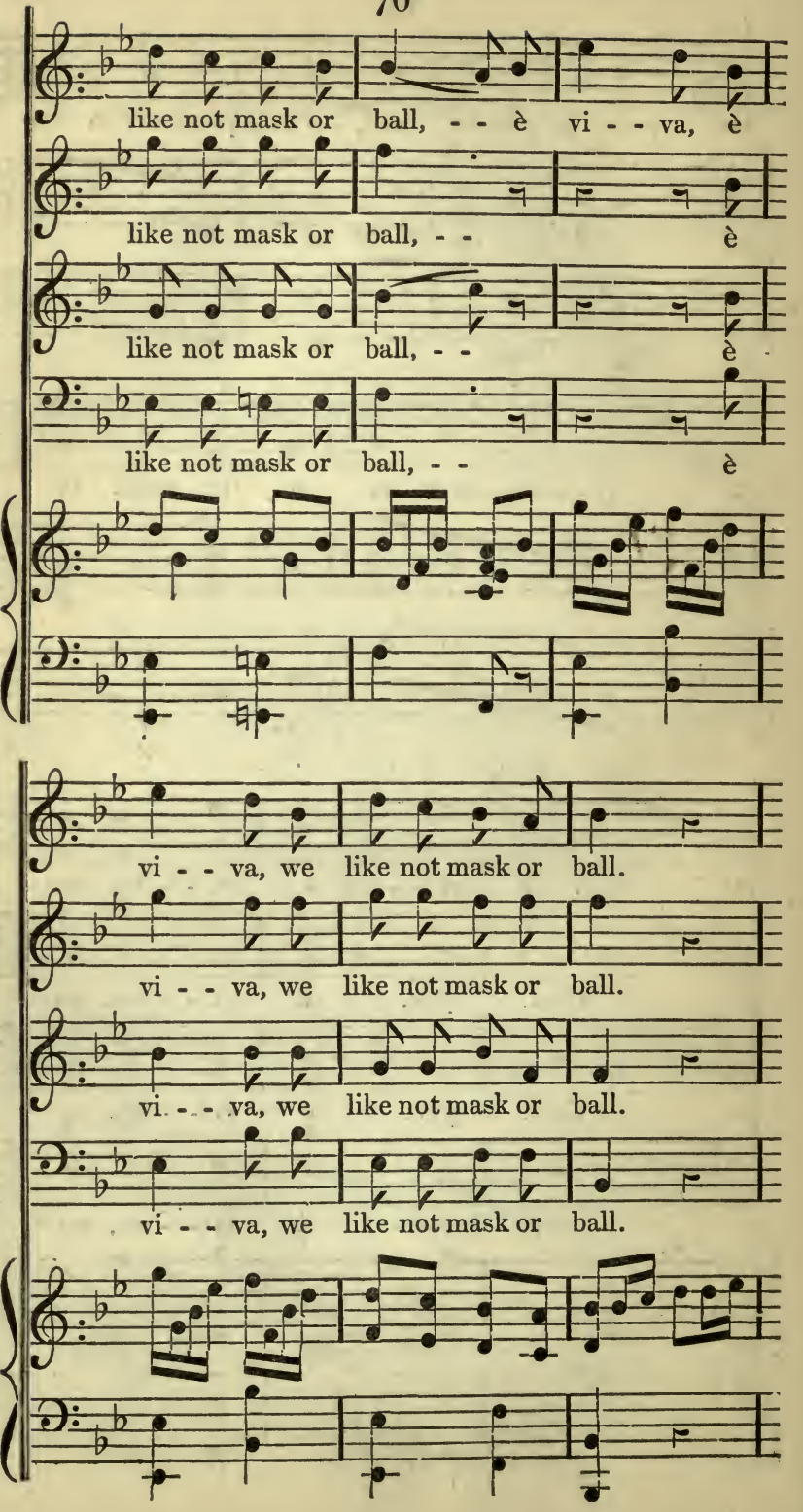


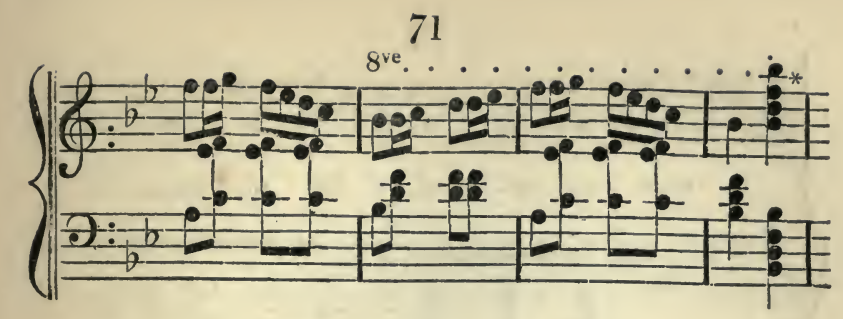

Solo.
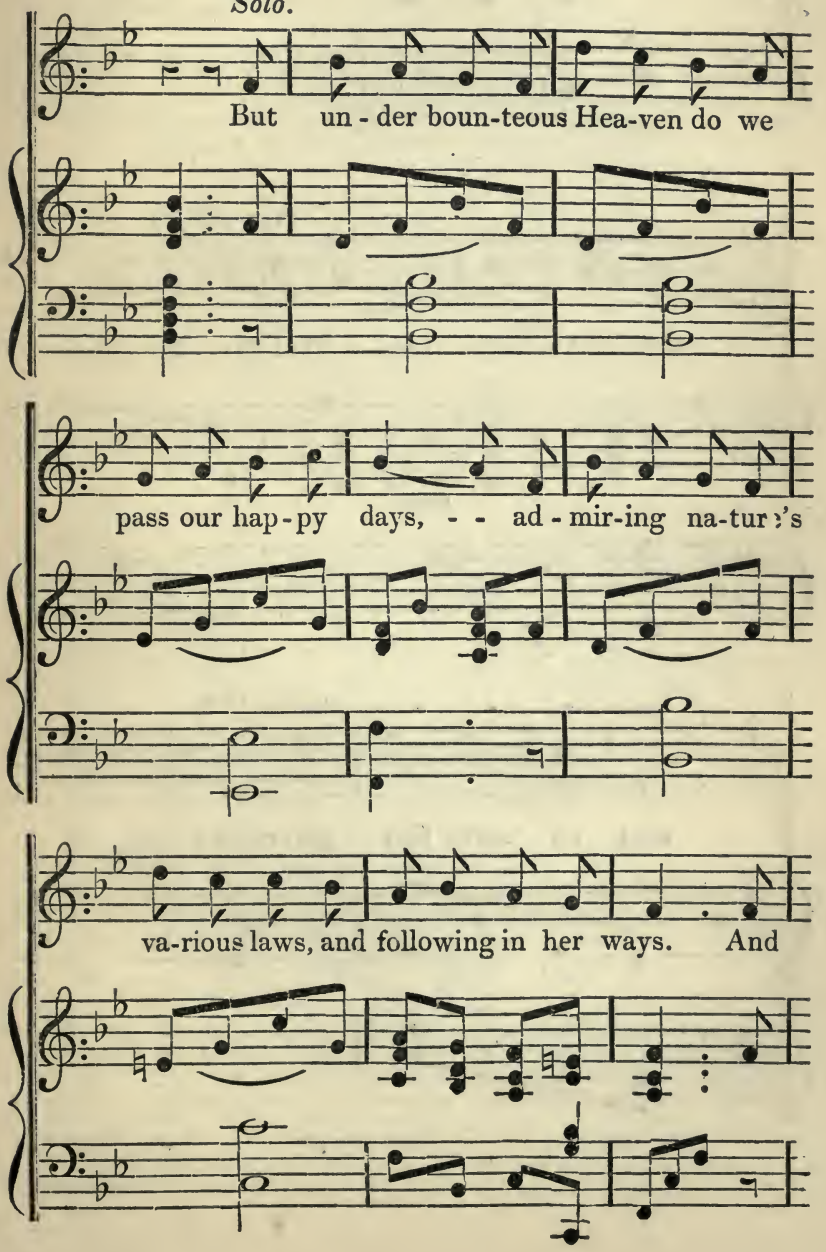
72
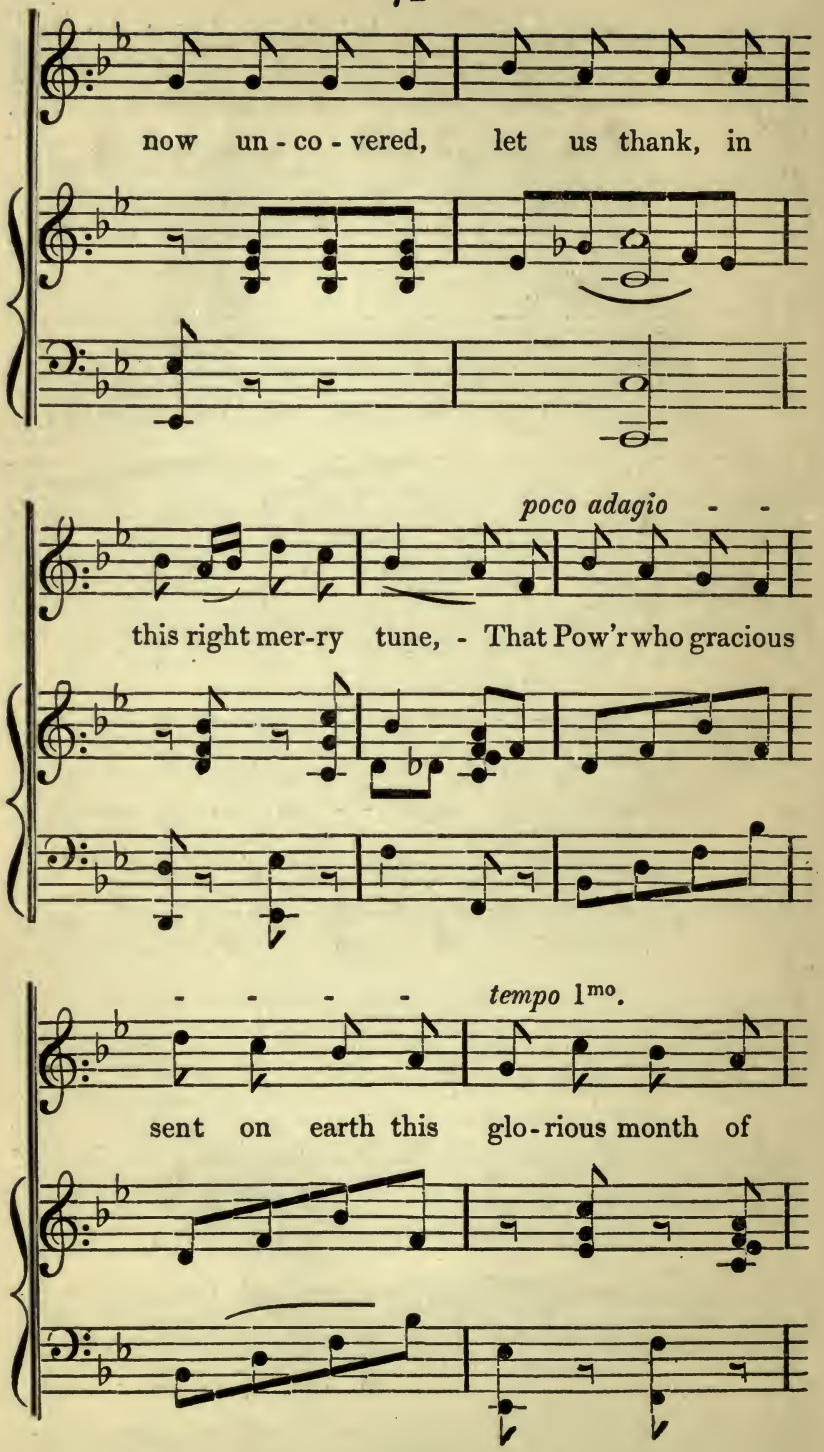


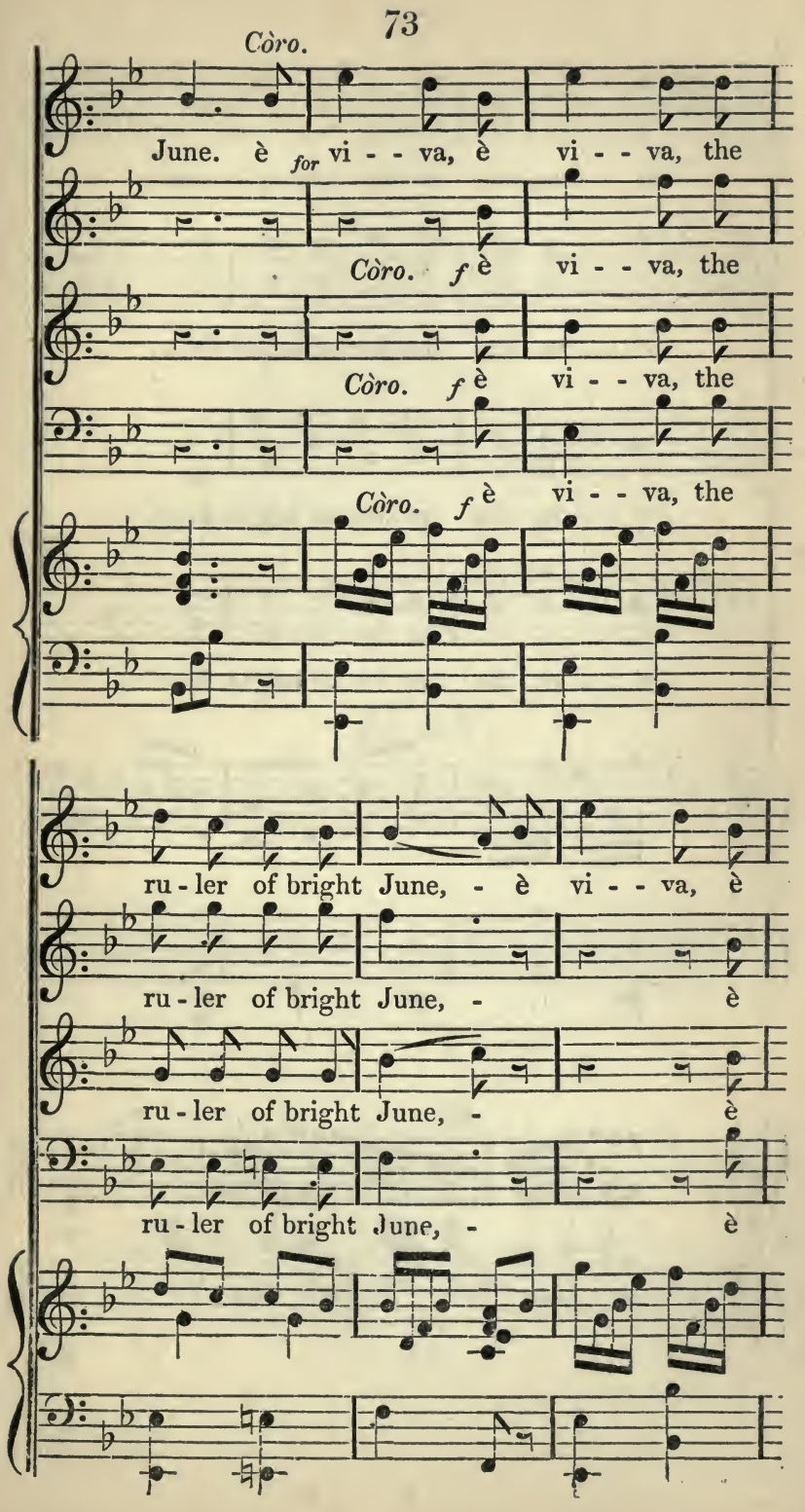




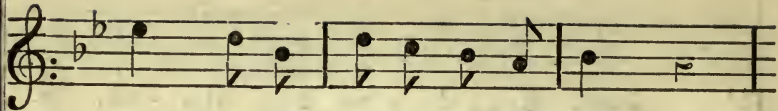

vi -. va, the ru-ler of bright June.

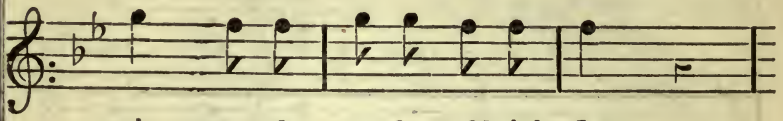

vi .. va, the ru-ler of bright June.

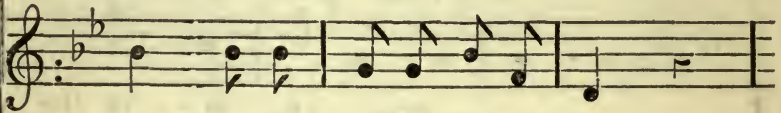
vi -. va, the ru-ler of bright June.

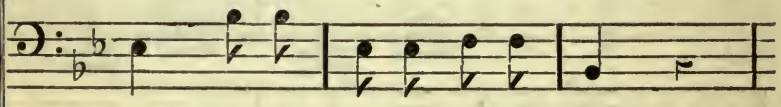
vi .. va, the ru-ler of bright June.
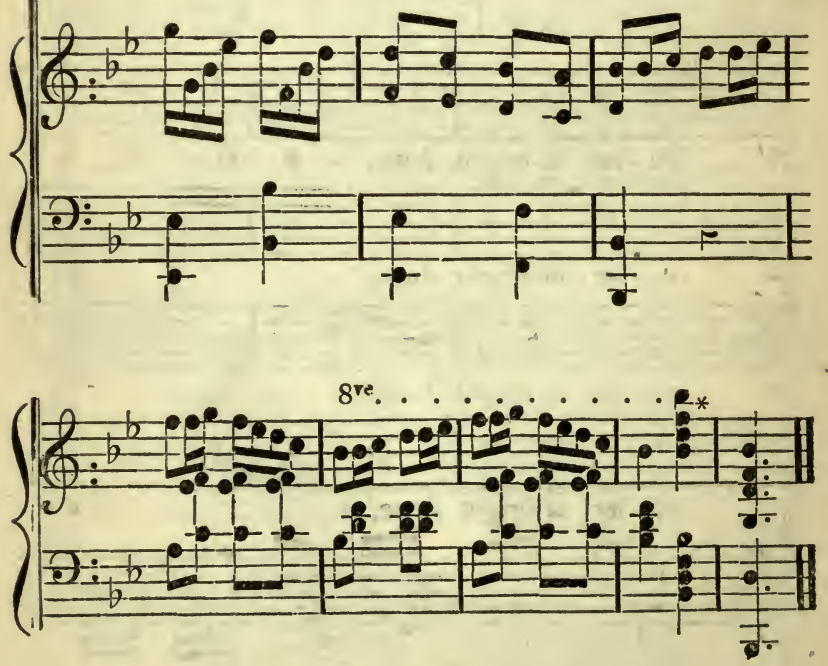
JULY.

E 2 



\section{§) IIly.}

JuLY bursts forth in all its panoply of splendour, and the fields are covered with a cloth of gold; the corn-flower and the poppy deck the pattern, and brocade each bank with modest yet most curious harmony, each vying who shall best display the great Inventor, Author, and Designer of it all. Her breath is perfumed as Arabian wind, that scents each bough it passes, turning our barren heaths to beds of roses. The birds sing sweet hosannas on the loftiest trees; the early lark triumphant greets the day, then yields her vespers to the nightingale, whose grateful bosom swells to pour the lay; and listen, how it warbles there!

Then shall the song of man be backward in its praise, and yield to the unreflecting throng 
sole power to extol? Shall he who marks the linnet in its nest, who listens to the lark's gay note, the nightingale's appeal; who guards the harvest, tends the flocks, observes the day in all its varied hours; who views the heavens and their ten million globes, and wondering stands o'erwhelmed in thought-amazed at all, yet comprehending none-shall he withhold his lay? If all that thou art allowed is merely power to praise, to join the vocal tribe in higher sentiment of song, to enjoy the artless life of our delightful recreation, let thy mind sing, and as thy soul shall prompt, GIve voice.

In after life, thy sketch book will insure thee pleasures that might otherwise be wholly lost. It will enable thee, on thy bed of sickness, to roam o'er many fields; to ramble by the brooks, to walk up shady lanes, and see again the very parlour where thy dear companions (now perchance no more) have passed the happy hours of evening. Thou shalt even hear their voices, and again attempt, e'en though thy voice be feeble, 
the gay and grateful song of former years. Thy dreams will be pleasant as thy early days were happy: waking or sleeping, thou wilt feel thy youth creep over thee again, and wield the pliant rod with all the freshness of eighteen.

I have heard thee sing, looked over thy sketch book, and well know thy art and observation. Shall Johnson now belie our recreation, and treat us as a band of idlers?-shall our great schools of learning dare withhold us praise, and spurn our primitive pursuit?-shall science blot our memories from its page, or sages scout us? If this is really the true Angler's life, I hear them whisper, No! This, then, it is ; and there will come a time when we shall have a college of our own, and concentrate the learning now too wide apart.

In the evening try alternately the Coachman and the White Moth, using the latter most frequently when quite dark: the Wren Tail is an excellent fly, suited to all streams, and admits of a variety of colour, as the green, 
light brown, \&c. \&c.; you will frequently find it on long blades of grass, when in all probability it is not in an active state, the sun not having been sufficiently out. I would, however, take one and throw it on the water; if the Trout seize it, let it be followed immediately by your artificial resemblance, and you will find the whole stream on the alert: for I have invariably observed, if one fish rises the others take the hint, imagining some treat in store to please them. I have a strong objection to all flies that must have two or three whisks of hackle at the tail; it leaves a long ripple on the water, and makes a sad disturbance. In very clear streams, the Pale Dun is good; Silver Horns is a sure card in wet weather, and lasts a considerable time, even through the next month; the small dark Spinner affords much pleasure to the trout, and also lasts till far in August. The varieties are not so great in this month as they are rich in many tints, each fly changing twice, except Silver Horns, others three or 
four times, so that you obtain a multiplicity of tints, and often colour; it frequently would appear as though a new fly had been called into existence, did you not examine the form, when you will find it is a mere change in its constitution.

This month I always term my Midsummer Night's Dream; you count up so many beauties that have passed, anticipate such numbers to come, and all that is enchantment still hangs over you. Many seek upon the Continent imaginary beauties, that exist in reality at home; but I will wager our Welch hills, our English meadows, Scotch torrents, and Irish lakes, against the whole world: and our lovely summer!-Brother Anglers, list. 
SONG.

On a Sunbeam will I ride, On the Cataract's wild tide; In a Rose I'd pass the day;

On a Moth I'd wing my way;Be as light as Summer air, As a Primrose pale and fair; For each fancy do I sigh 'Neath a shade in gay July.

Can Italia's sun display Meadows richer, or more gay?

Can the viol or guitar Better sound in countries far? Can the voice have greater scope, Or the Poet brighter hope ? Let the wanderer go and try,Give me England and July. 
So I but my fancy please, So I fish and live at ease, Never seek I foreign land For abundance here at hand. Have we plague, or war, or toil ? Have we discords to embroil? Never leave thy streams to roam, While you've England, July, Home. 



\section{JULY.}

Allegro.

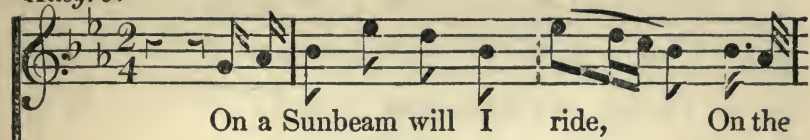

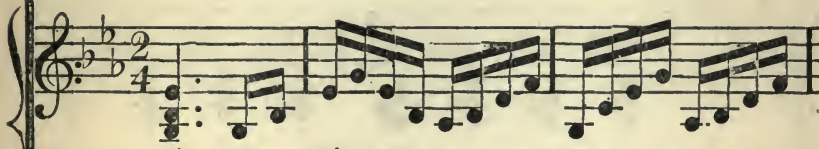

(5):

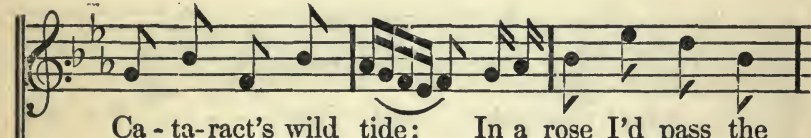

Ca-ta-ract's wild tide: In a rose I'd pass the

(

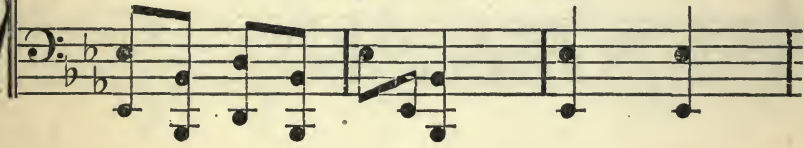

day: On a moth I'd wing my way: Be as

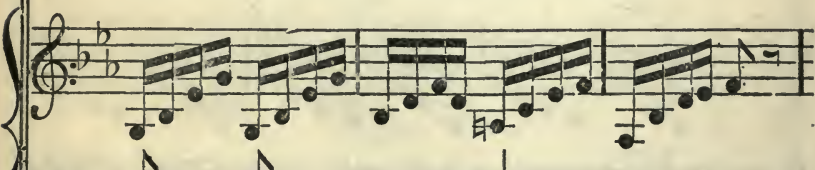

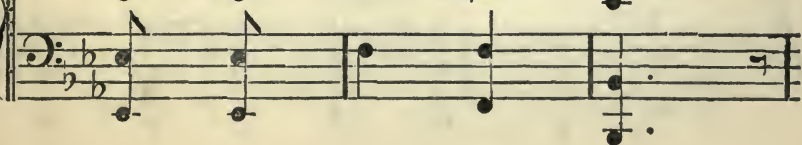


86
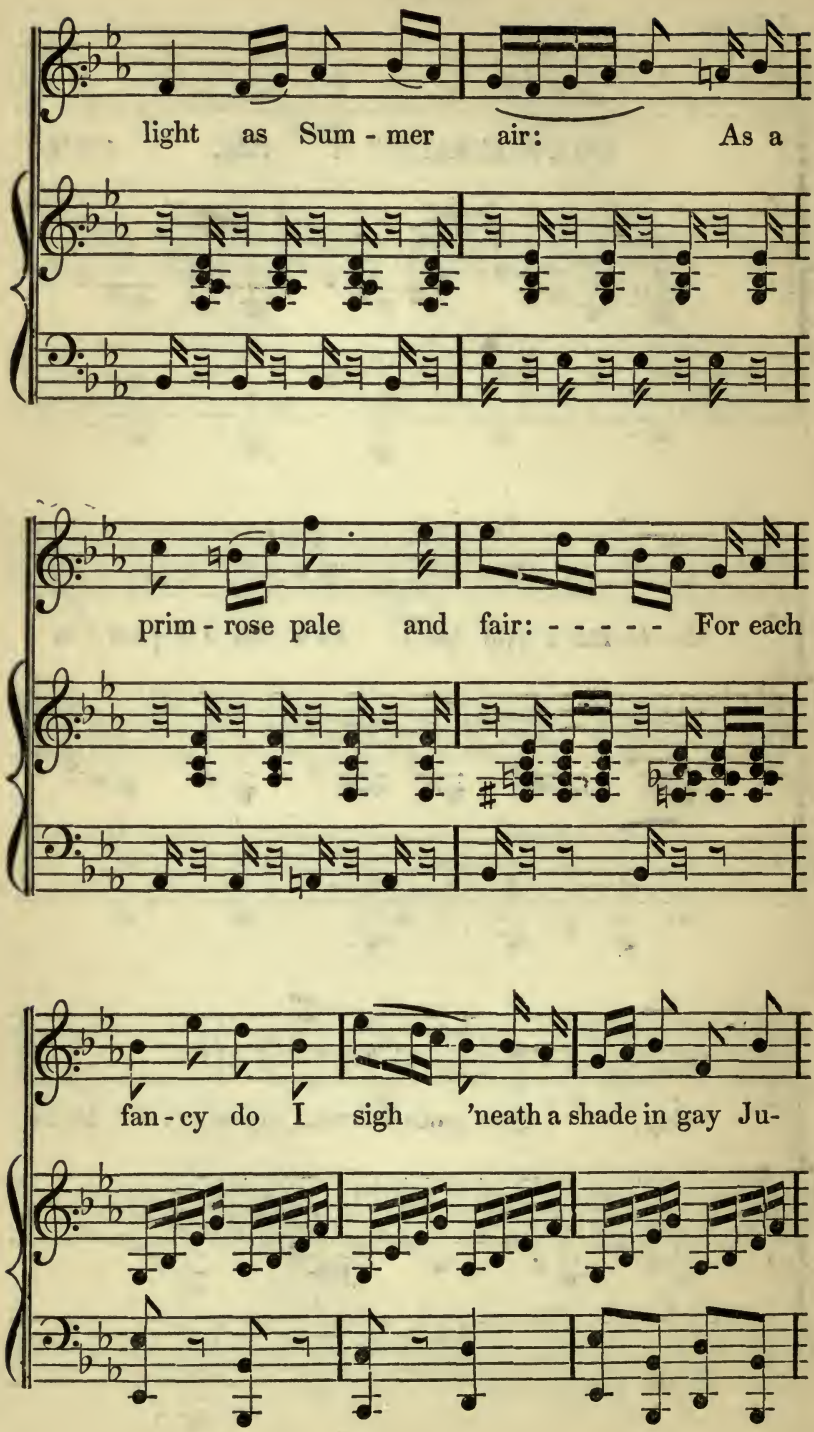

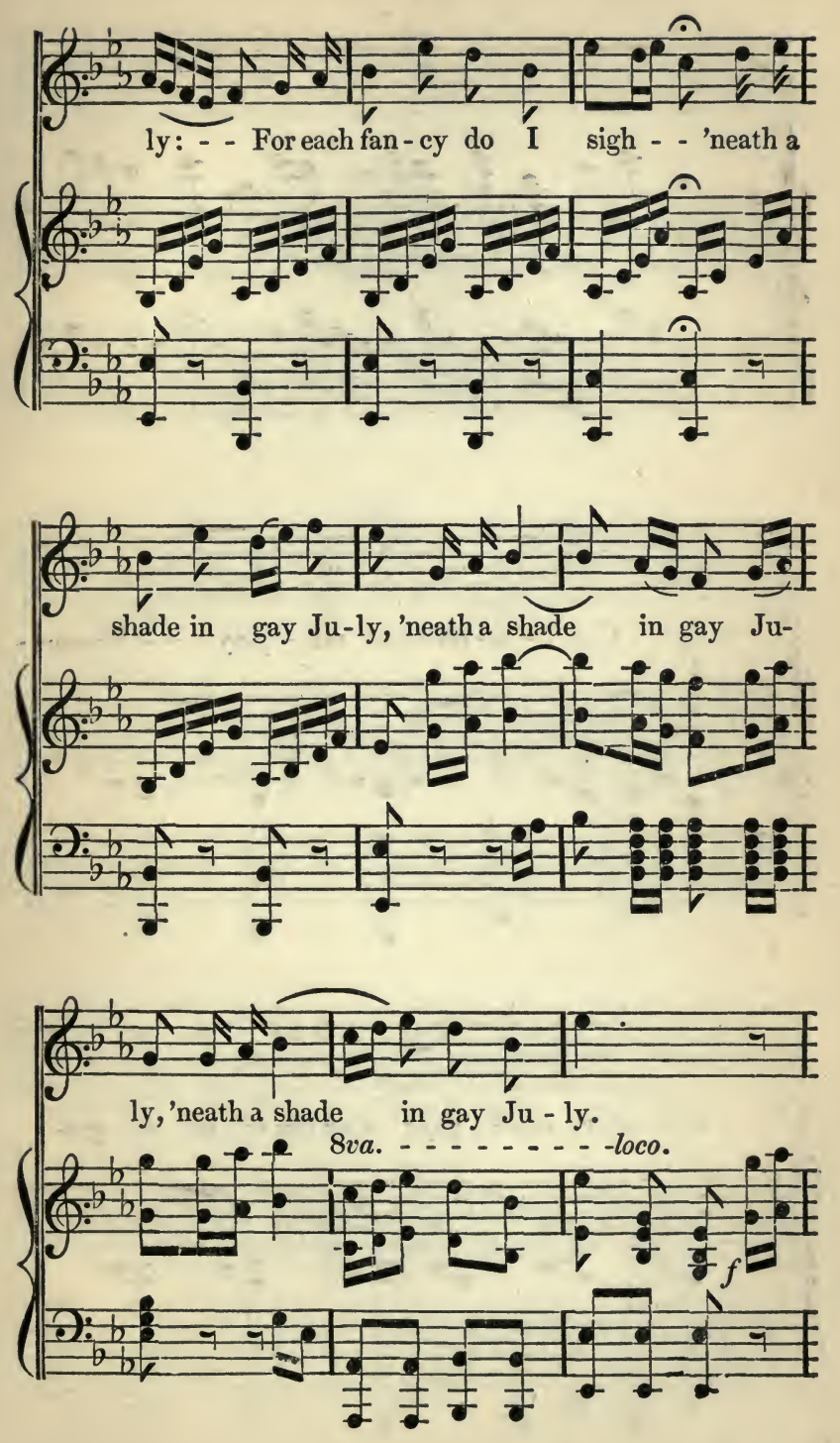
88


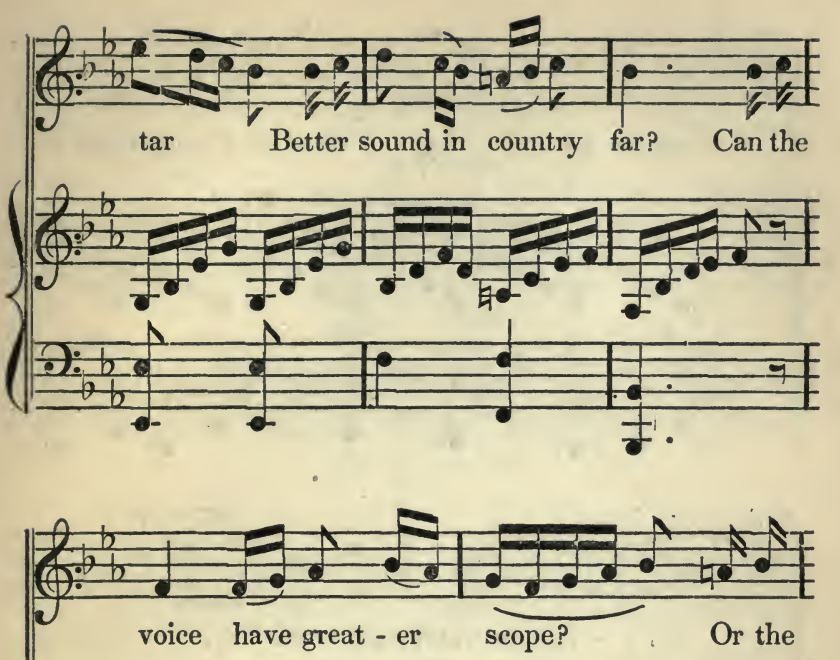

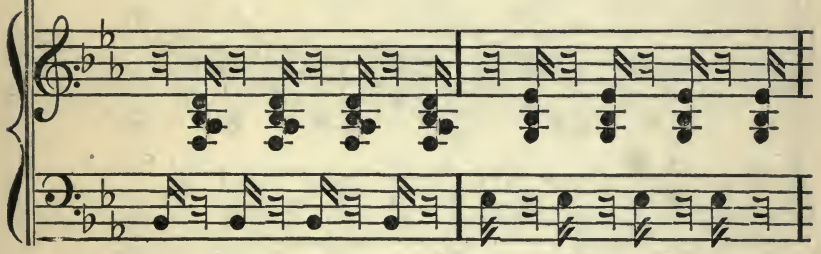

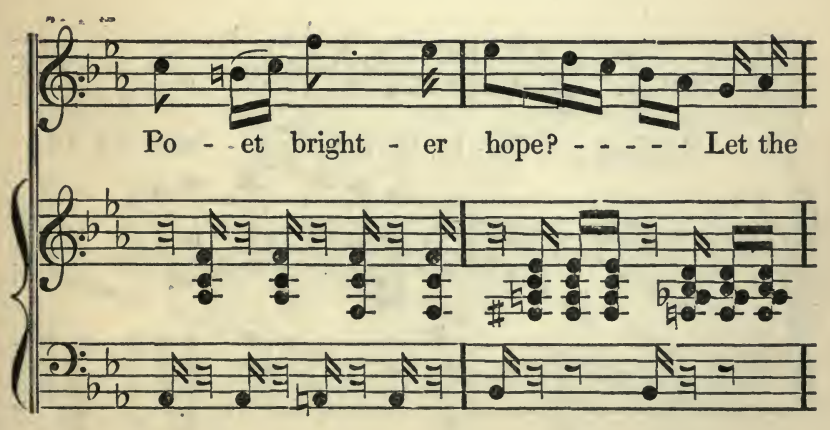



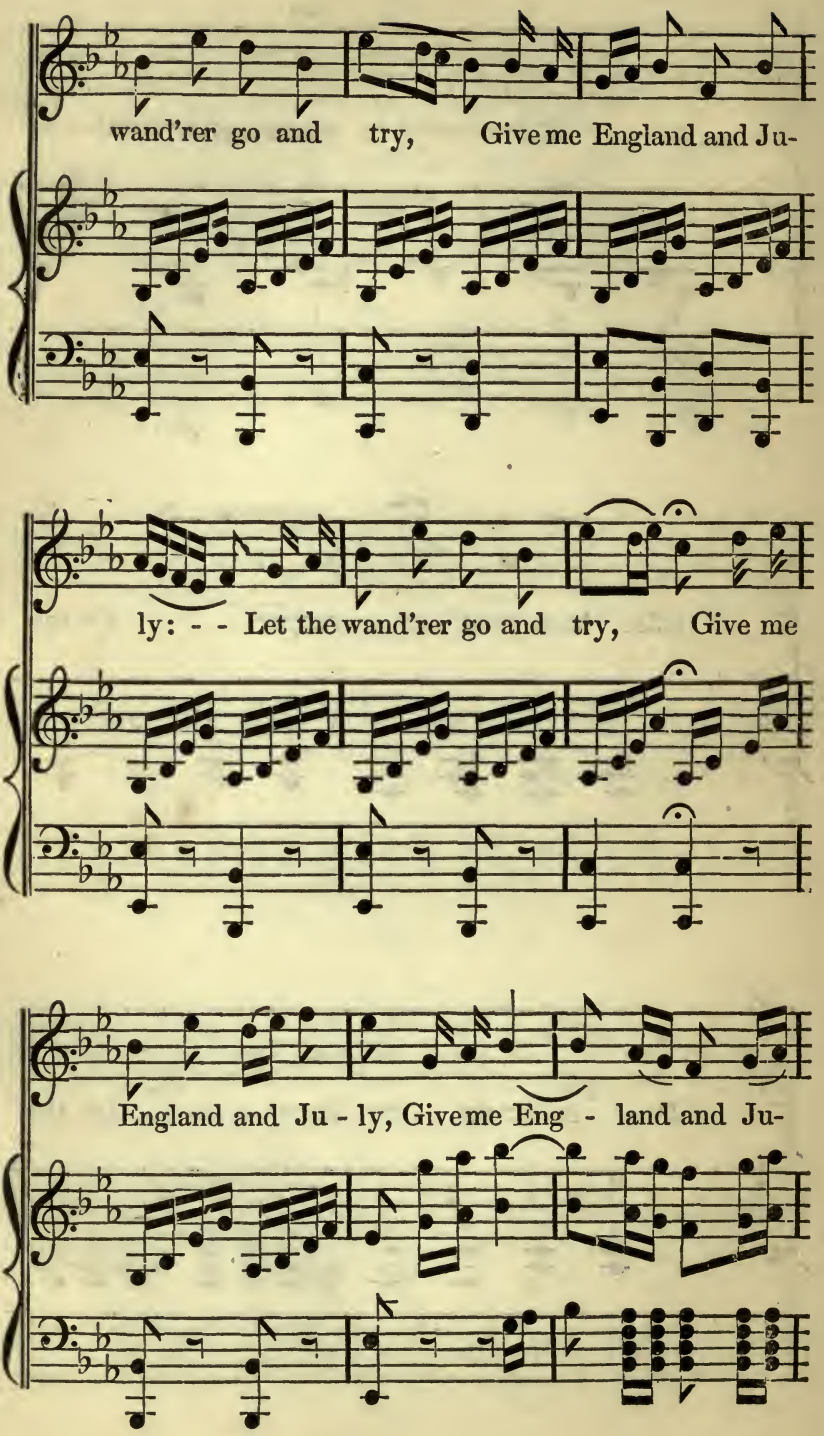

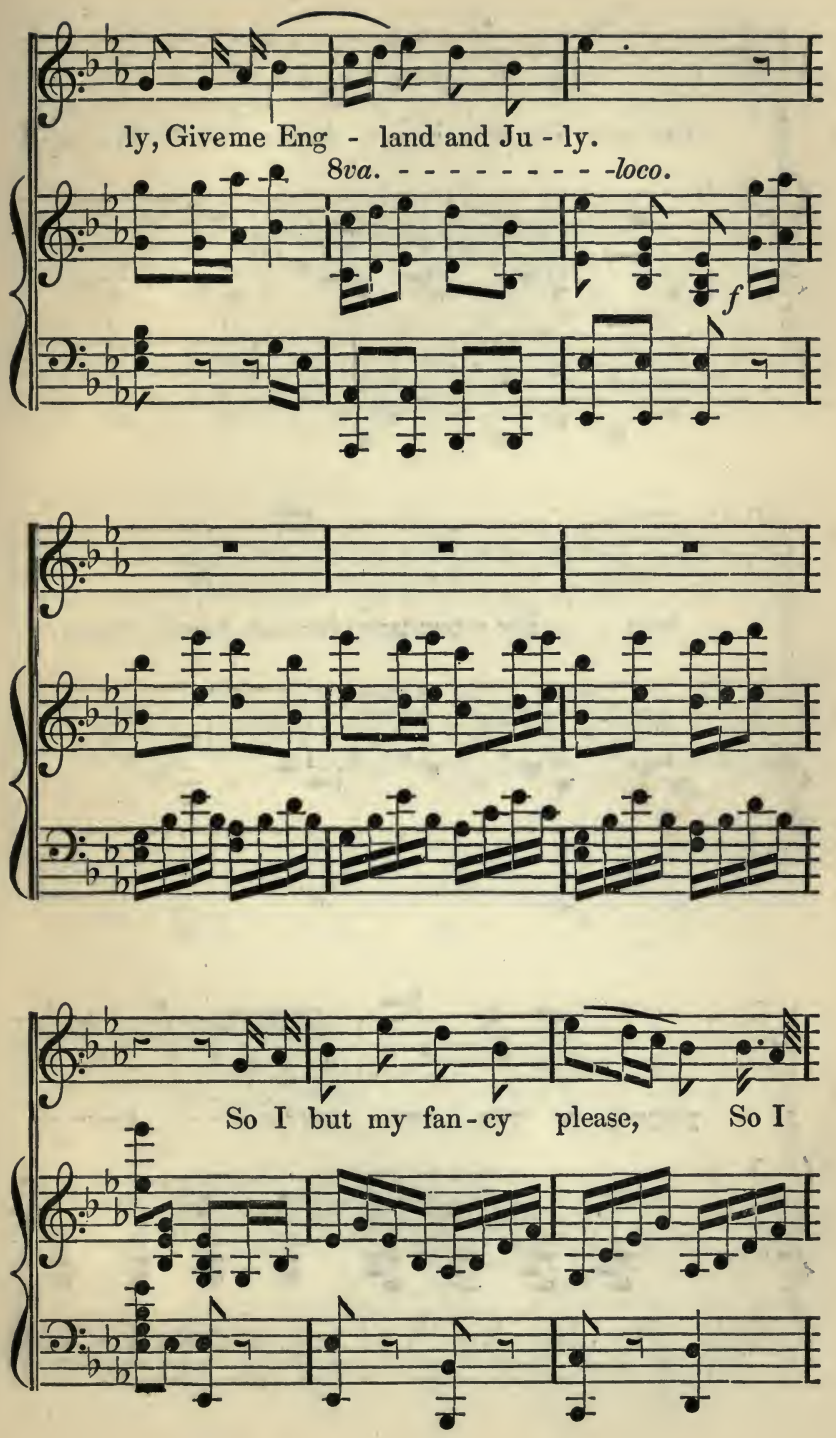

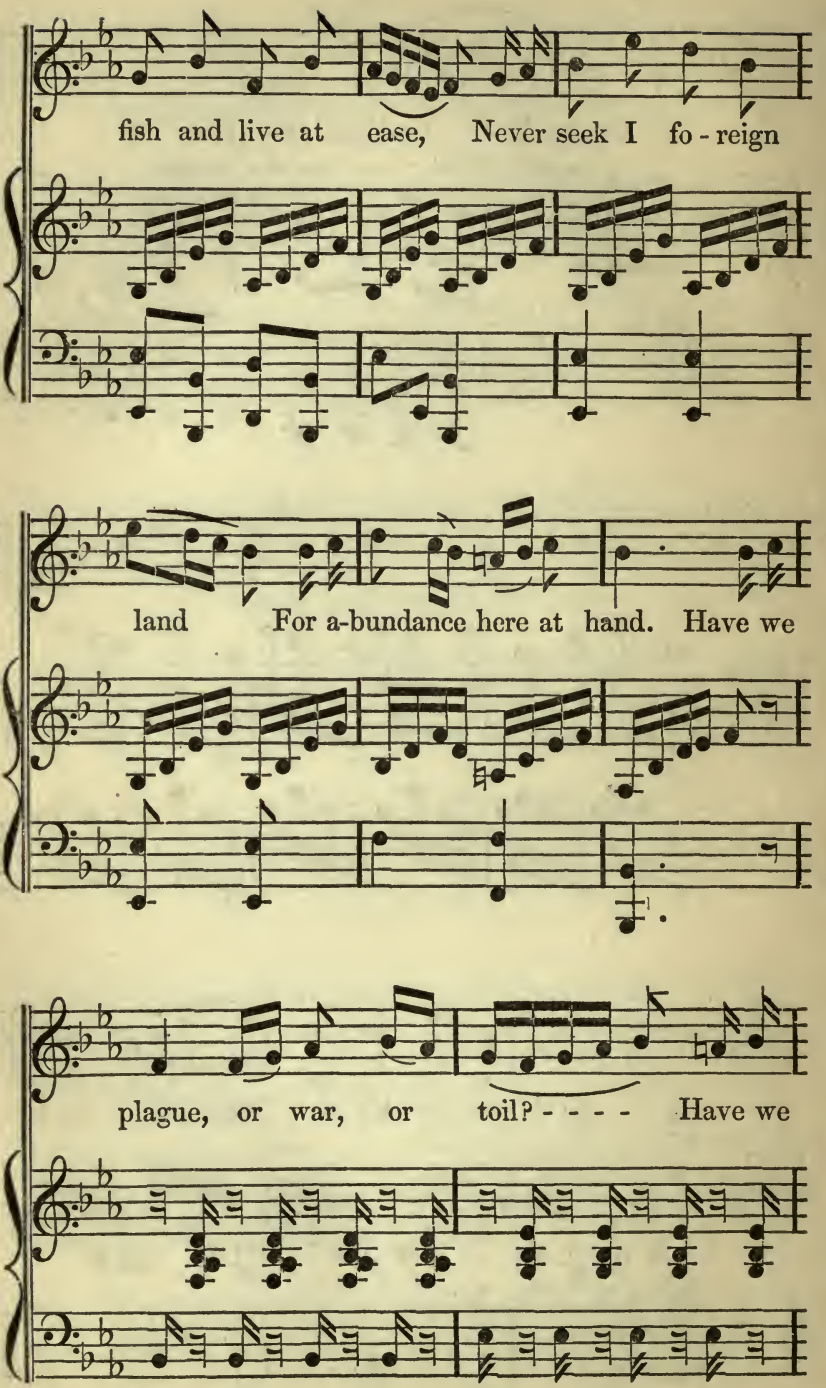

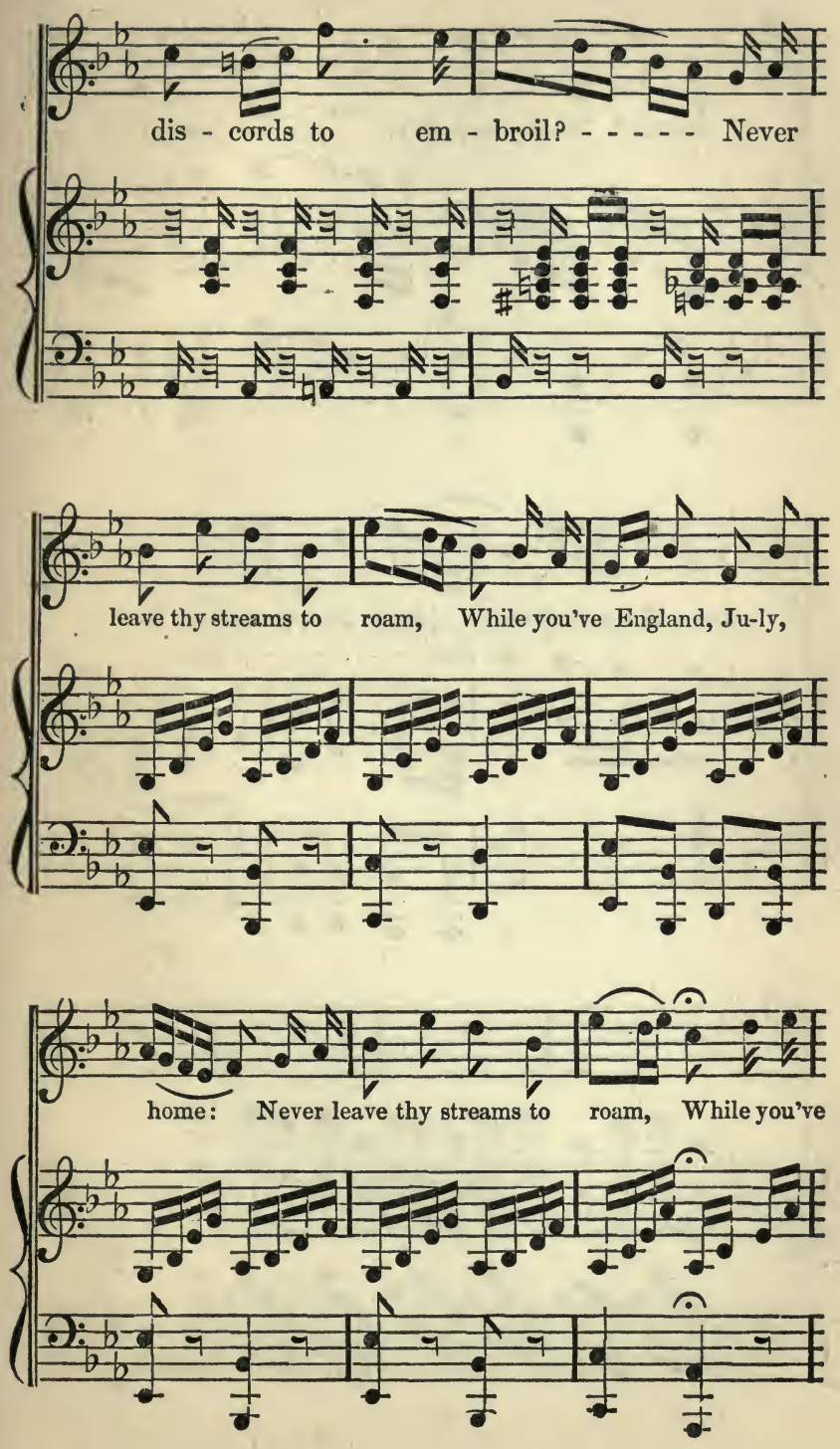

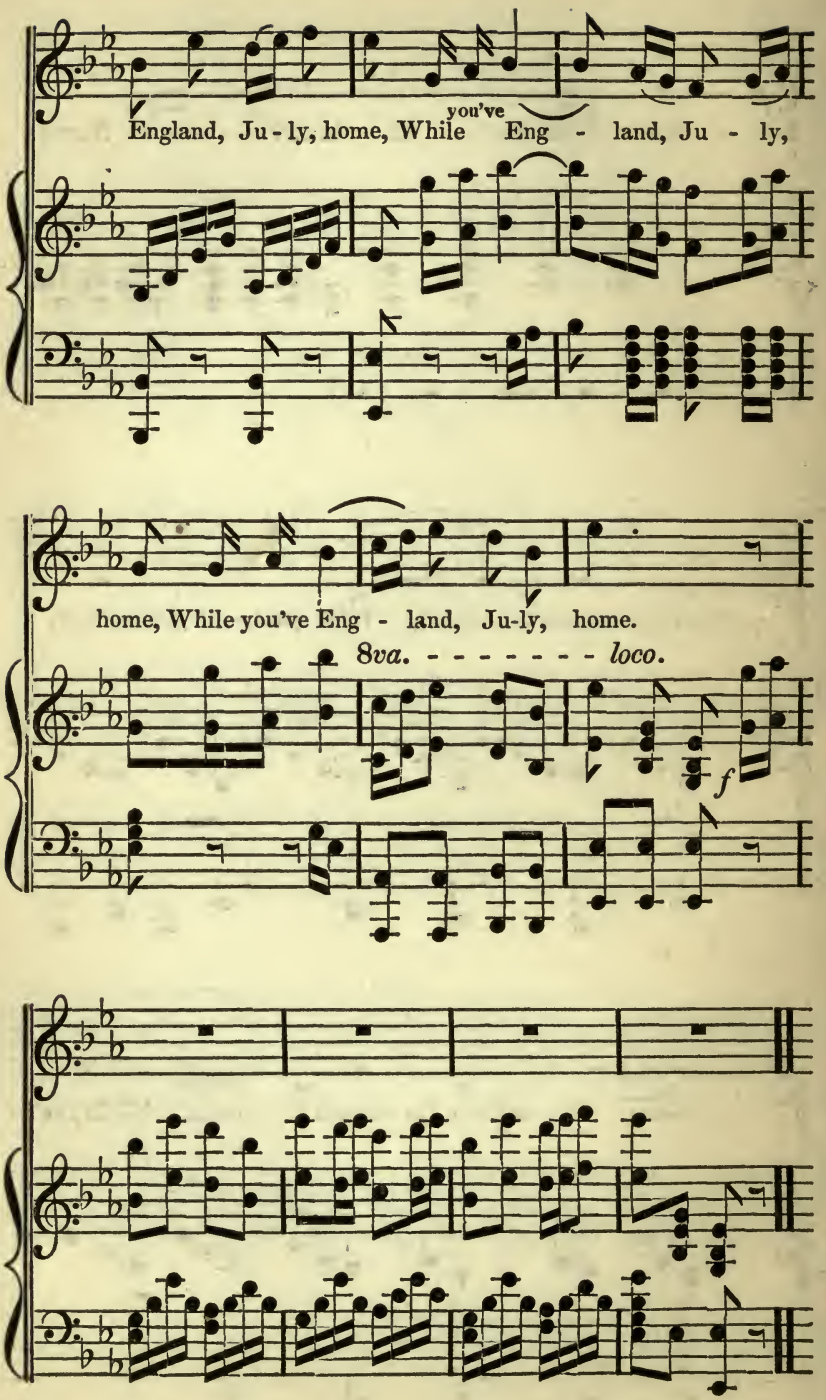
AUGUST. 


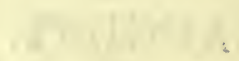




\section{สuฐust.}

August, I crown thee Monarch of the Year, for Nature now in grandest garb is dressed; thy treasury is crammed, thy robes are gold, sweet smiles bedeck the brows of all thy subjects, and thy ripe fruits burst with the weight of their luxuriance. Often have I pondered o'er each varied month, and equal seems to me their beauty; by the contrast of our cold we love the summer; from relaxing heat we revel in the bracing breath of winter-all have enjoyments, if they've health and a contented mind. Let those of other mould embrace our art, and speedily, ay, speedily, they'll change from the abject and dissatisfied hypochondriac, to the happy, healthy, and most joyous Angler. 
"Fair Ceres calls to join her jocund train,

Pours plenty in our laps, and bids us laugh at pain ;

Sweet Goddess, we are thine, and smile, and laugh like thee, Crown'd with thy garlands, happy, rich, and free."

We are the happiest of the human race, that want but little, and have all the world affords ; well may our bard exclaim,

" $O$, the pleasure of the plains, Happy nymphs, and happy swains !"

But stay, hitherto our recreation has been selfish, confined entirely to the male creation; yet there is vast scope for the enjoyment and participation of the other sex, without the toil or stratagems, as shall be seen. About noon on a fine day, how delightful to rest while the sun is in meridian, and be joined by your fair partner to lunch under the shade of some widespreading elm, and afterwards pencil the surrounding scenery! What charming views such opportunities afford; a world of vast discovery, which, but for our enthusiasm, would lack the 
ornament of their presence, and fair Nature yet be wanting its most noble, most intrinsic gem! I could write volumes on this subject, but should diverge too far from my path, and possibly, in admiration, even lose my love for Angling. Yet this believe; a stolen visit in the day, and cheerful welcome in the evening, with congenial feeling in success, must frequently enhance the value of thy pursuit, and make thee more enjoy the mere muster of thy brother Anglers, when amid the laugh, the song, the jest, you steal a moment in quiet recollection of the contrast.

Before I speak of the Flies for this month, I would observe a circumstance that might materially serve you on a strange stream. The eye naturally wanders to the first shallow or swift corner, and no doubt but fish lie there. This, however, is a better criterion; the Trout must always have something to look at, and it may be proved by the following experiment :-Select F 2 
some clear part of the stream, and throw in a stone sufficiently large to cause a parting on the surface; in less than half an hour you will find one of the finest fish in the river, about a foot below it. They invariably select such.spots where the water parts on each side of their nose; and if you throw and take him, another half hour will see his place supplied, and so on ad infinitum. Therefore be sure, that after you have tried the banks, look keenly out for the divided ripple; it matters not how it is produced, whether by a stone, tree, bridge, stake, anything, so that the trout has an object before him, -there he lies. The cause for this instinctiveness, I take to be the smooth water in which he abides enabling him to see better the small particles of food which may pass on either side. I could mention twenty modes, by which you might ensnare the fish, even with your artificial fly; but as I am strongly opposed to all but the fair, open, and skilful throwing, I 
must confine myself to this one method; added to which, I would not sully so fair a month with such vile stratagems.

The Red Spinner is an excellent fly for August, in fact, the most essential ; it lives for a considerable time, and frequently sees out September. The July flies will best attend the one above, of course regulated by wind or rain, each being more or less destructive to the insect tribes. Till September, a white winged fly in the evening is always best; and you will find towards the latter end of the year, as even now, the finest trout lying near the mill head: when the water thickens, then is the time to entrap them, if at all inclined to rise, as, by sinking the fly a little under, they are deceived, when in clear water you would be treated with perfect contempt. There is nothing more amusing (though I must say sometimes more annoying) than to see a fine fish lying at his ease, and suffering your fly to pass quietly over him, nay almost touch him, till, seemingly disgusted with your folly, he 
leisurely moves a few feet lower. I am almost ashamed to speak again of the Coachman, but rely on it, if you are anxious to gain ground, you must give the reins to the Coachman.

In this month I entered on my worldly career, and had (as I grew up) flattered myself that I was, for my age, (being then five and twenty,) as expert and experienced an Angler as you well could meet withal; but, as a would-be learned lady once said to me, you must not lay that curious unction to your soul. I met a young gentleman about twelve years of age, wielding the rod with wonderful dexterity, and, (as his basket proved,) extraordinary success. You may imagine my surprise at one so young, possessing such unbounded skill. When I questioned him upon its origin, he informed me that his father was a neighbouring clergyman, a great and enthusiastic Angler, by whom he was encouraged to become the same. "You may think," said he, (with a very arch smile,) " that so young as I am, my time might be better and more profitably 
employed at school, or in a thousand different ways, but indeed you are mistaken; and were you as well skilled as myself, it might even add to your relish of the art." - "Nay," I replied, "pray inform me where I lack, or in what points you so far exceed my learning." - " Ah !" said he, "I cannot say that; but, judging from the way in which you have now two good hours traversed this stream, (for I have watched you closely,) I do venture you have much to learn."- "I pray you, then, inform me."- "I will," said he- "First, then, you must know, my father is a great scholar, and well versed in all the finer arts and sciences; indeed, in every thing that should constitute the character of a gentleman. Well, Sir, when I return home from my morning's sport, I produce my fish, and he questions me thus:- 'With what fly or flies did you take them? what quarter was the wind in? was it dull, or did the sun shine? what was the soil, and was it dry or damp? on what plant or tree did you first 
observe the insect you have imitated ?' So, Sir, you see, by these close questions, I become not only an Angler, but a Botanist, Naturalist, Entomologist, and Geologist; my afternoon being employed investigating the causes of the circumstances above described, and gaining health, by exercise, and knowledge."

I was so struck with the simplicity and truth of what he said, that ever after were my ideas entirely changed; since which $I$ have added to his store, music and painting; and still blush when I reflect on having lived five and twenty years, and almost as ignorant as the earliest August I ever fished in.

The first step towards being wise, is to know that we are ignorant; and here indeed it was most gloriously illustrated.

I will now to the little cottage I have taken near the stream. My wife, and most likely some friends, who have come to greet the anniversary of my birth, and share the next day's pleasure; wait my return. Yes-yonder I see 
the little parlour window open, and some one pushes aside the thick grown jessamine; a waving handkerchief salutes me-another now streams over the first one's head-and nowanother! At the door too-oh! glorious! All arrived; and-ah! by Jove, we'll have a merry evening. Now then a hearty greeting; we pass our hasty and anxious inquiries, and with hearts o'erflowing for the happy hour of meeting, and the coming morn, join in exulting chorus this truly jocund lay, which, echoing through the valley, wakes the languid eye of evening, as though the day had sunk too suddenly to rest, and was by us in meekness checked for its abruptness. 


\section{SONG.}

Come, hie along with me, singing Heigh, trollie, lollie, loe !

Sweet pleasures thou shalt see, singing Heigh, trollie, lollie, loe!

The fields and meadows fair, singing Heigh, trollie, lollie, loe !

The gems of earth and air, singing Heigh, trollie, lollie, loe !

In August I was born, singing Heigh, trollie, lollie, loe!

When golden fields of corn sing their Heigh, trollie, lollie, loe !

The streams and vocal throng, singing Heigh, trollie, lollie, loe !

Keep measure with my song, singing Heigh, trollie, lollie, loe ! 


\section{AUGUST.}

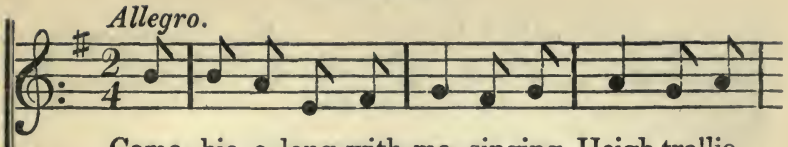

Come, hie a-long with me, singing, Heigh trollie
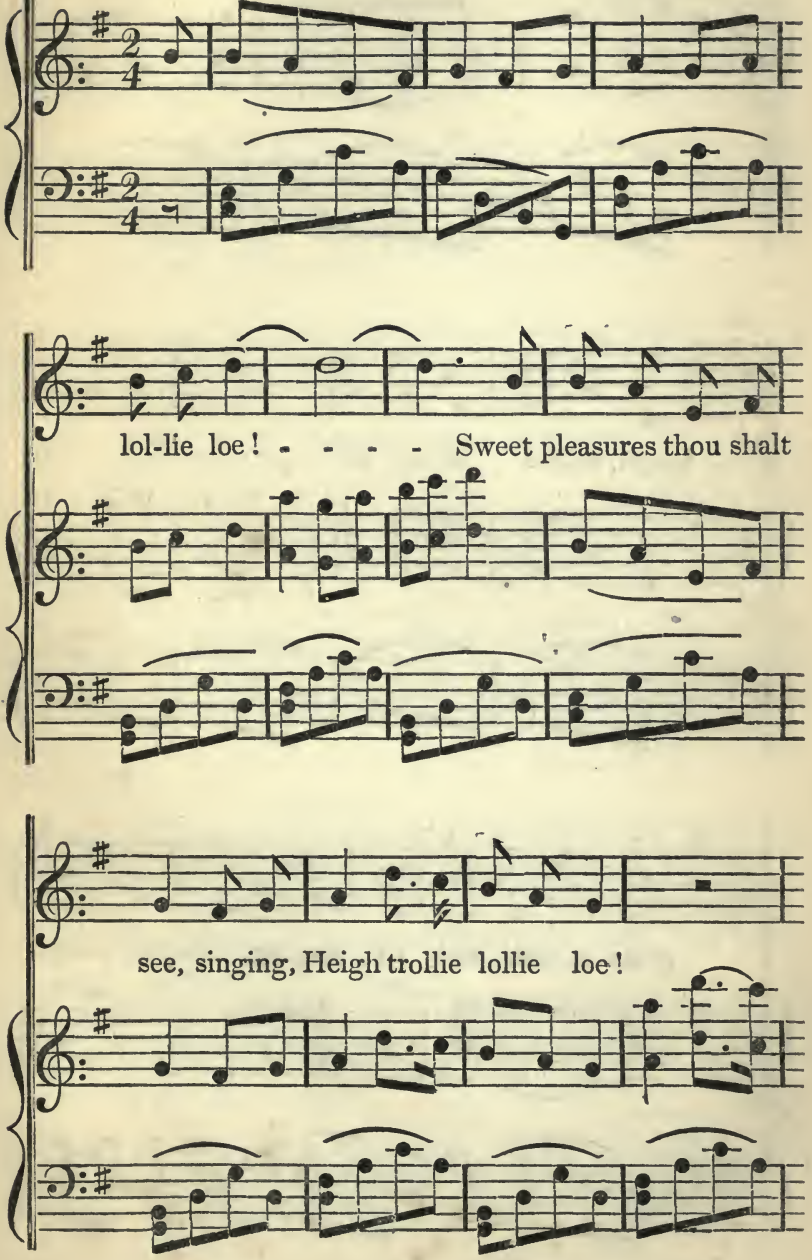

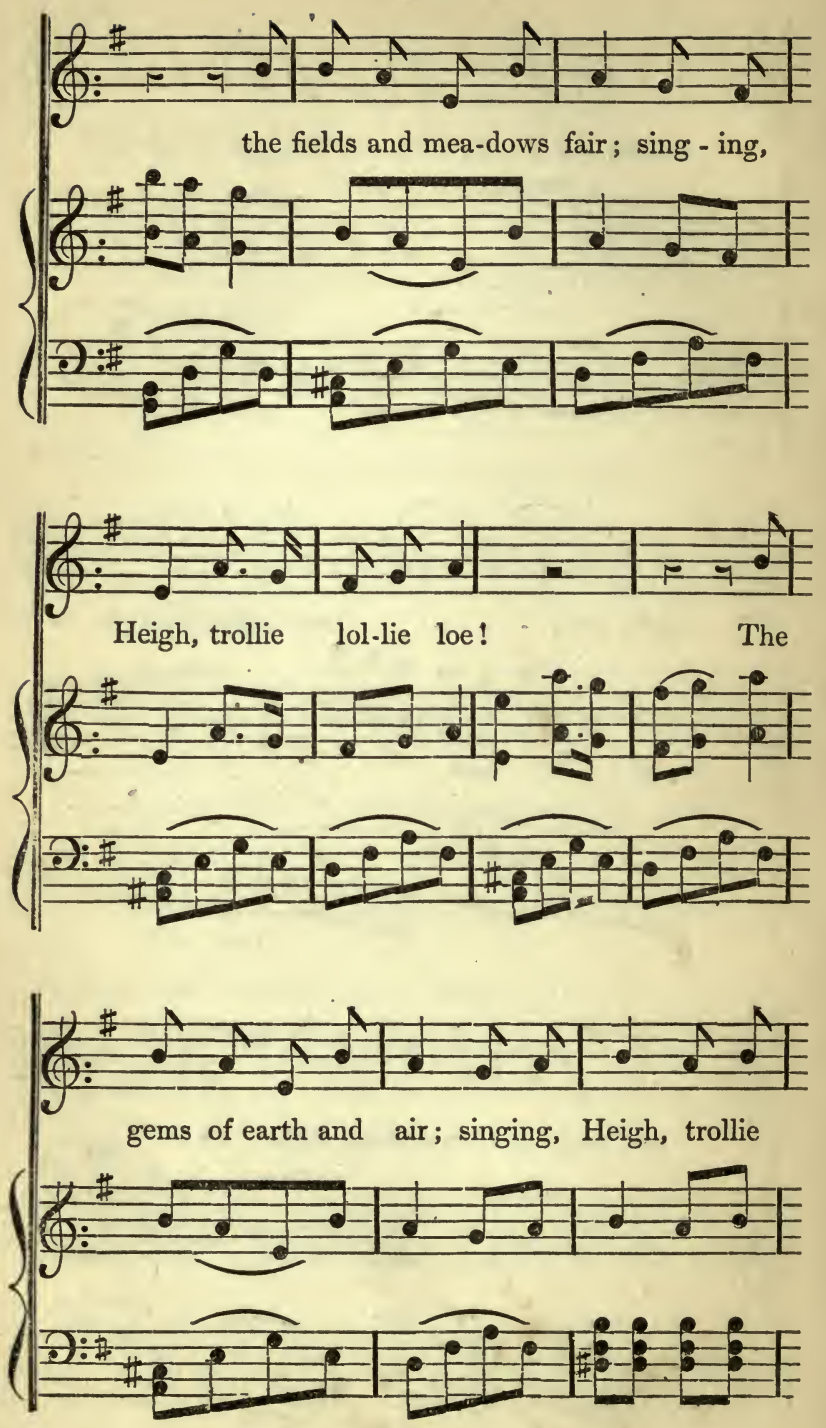

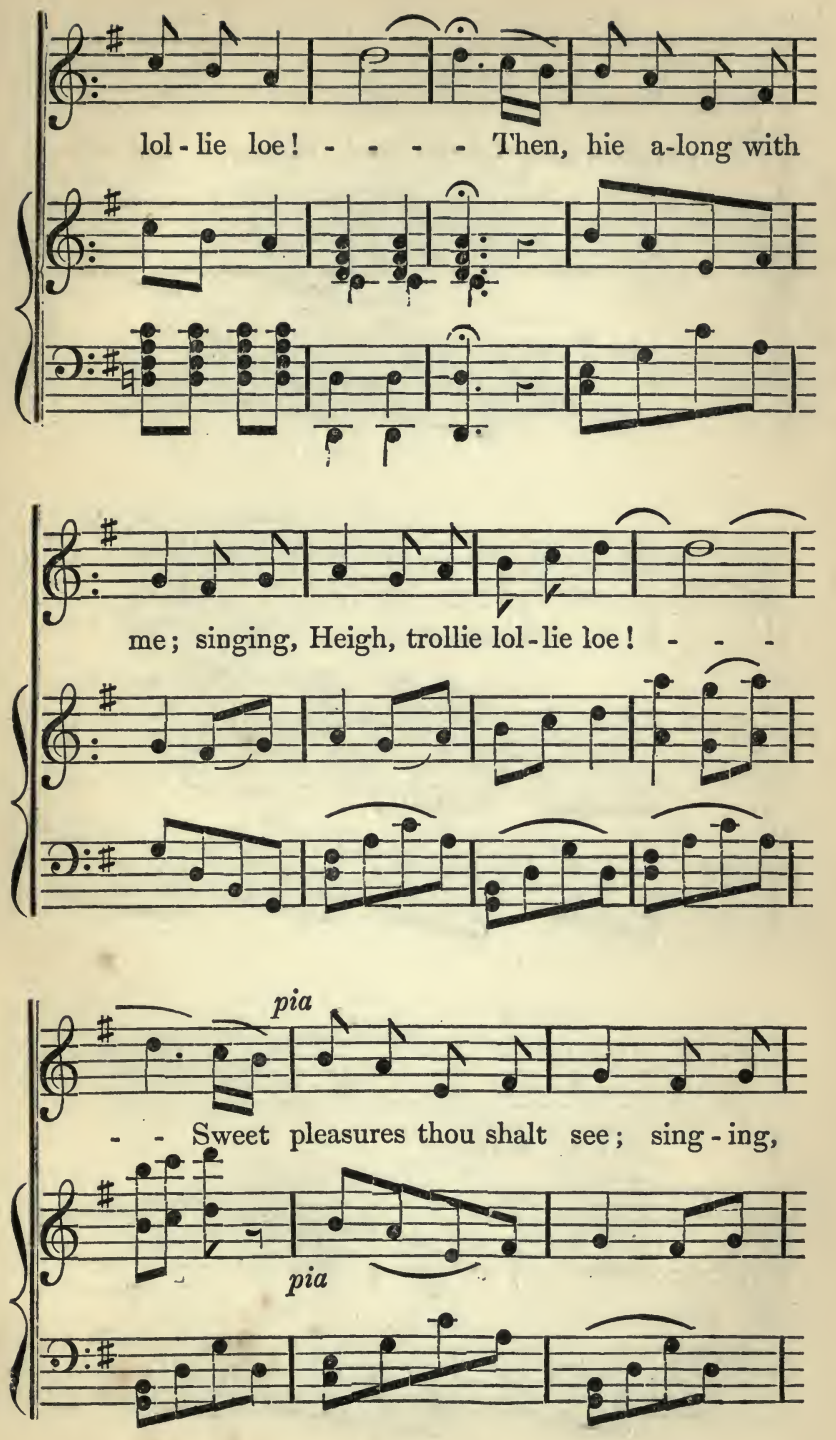
110
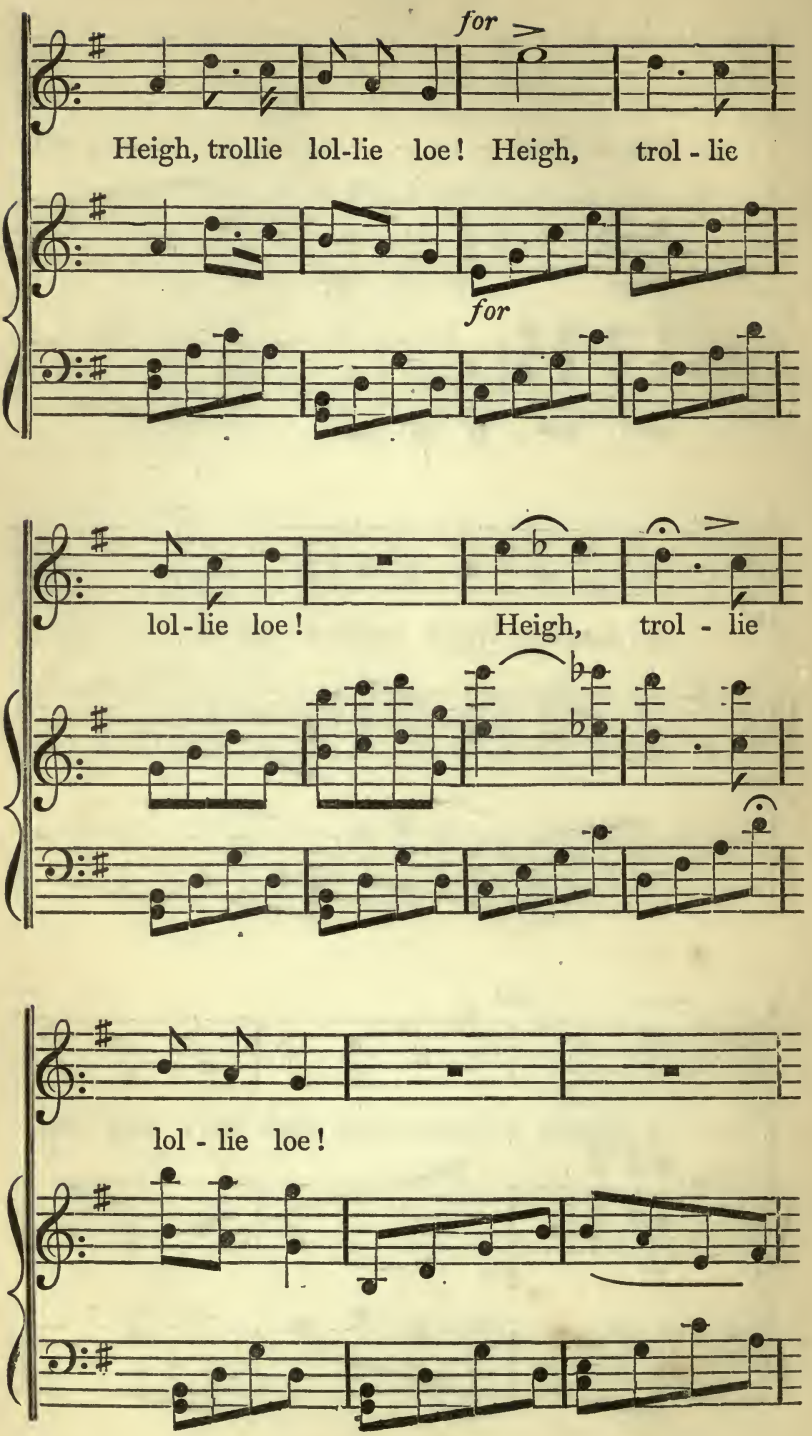


\section{1}
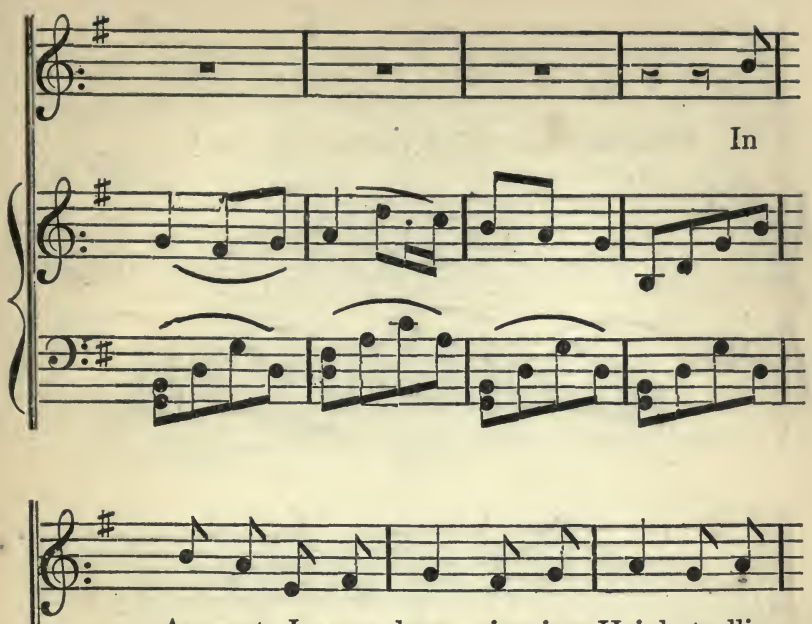

Au-gust I was born, sing-ing, Heigh, trollie
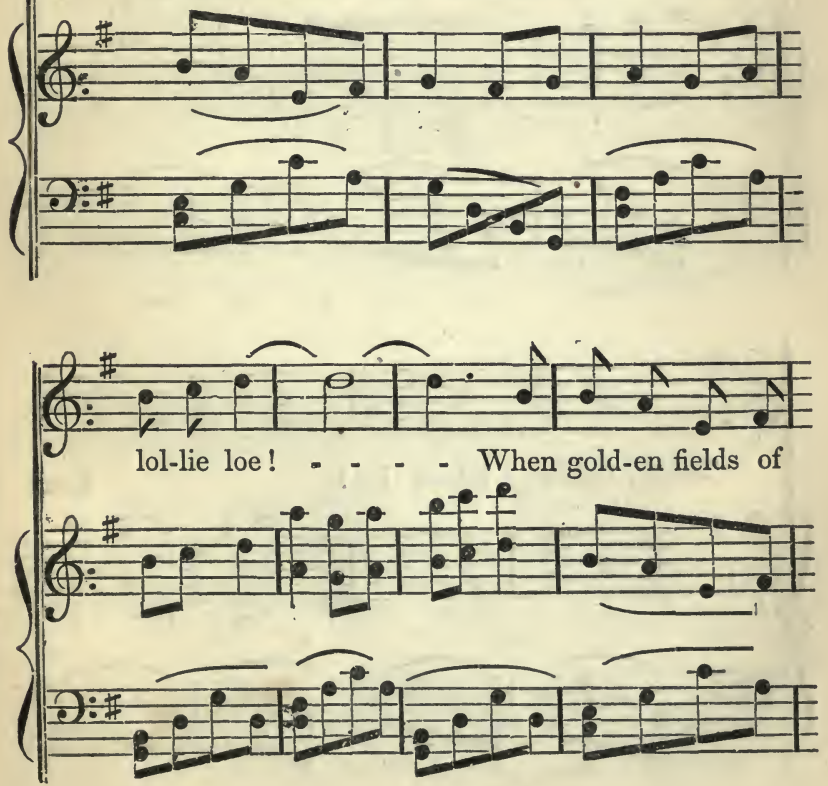

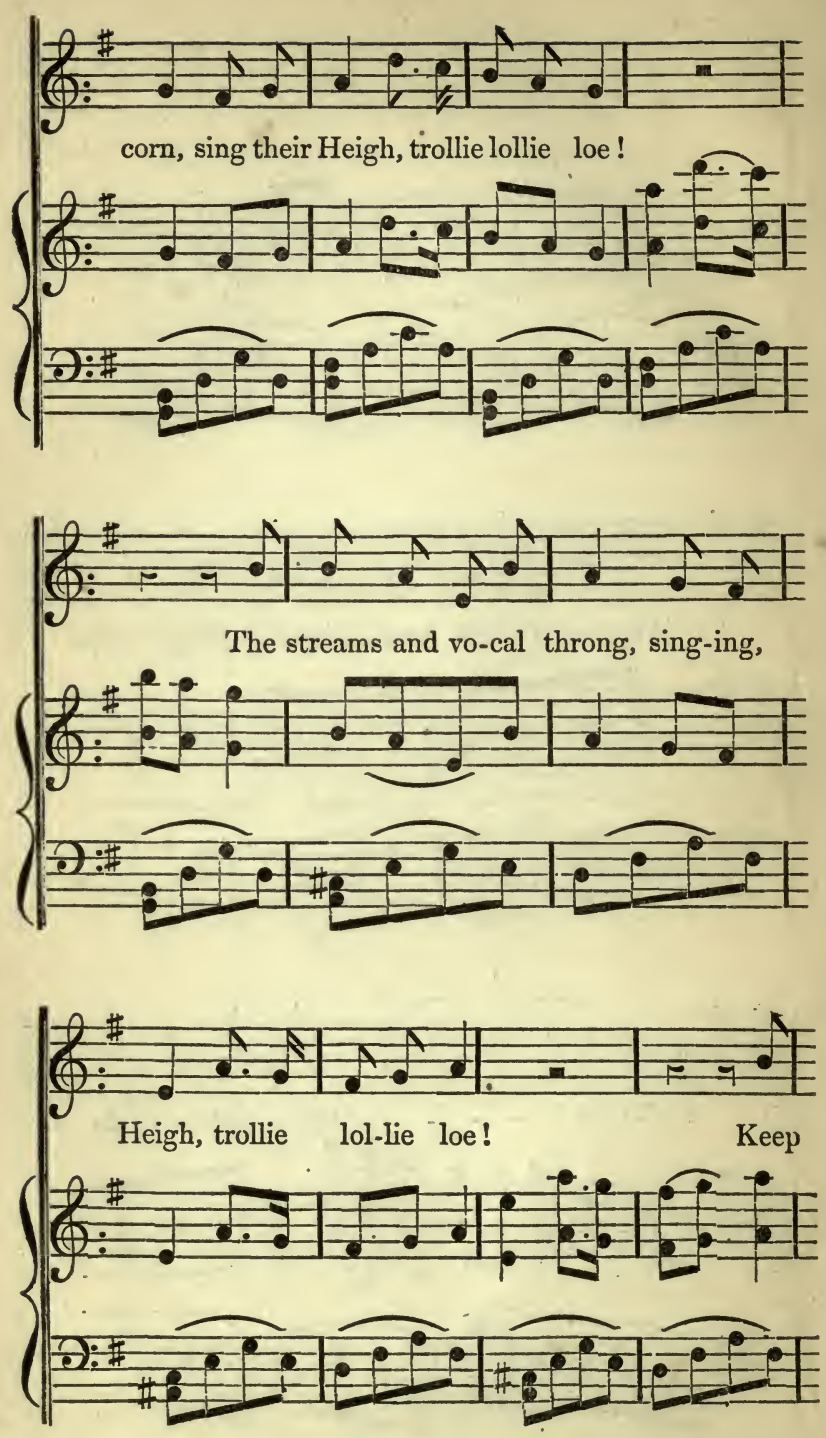


\section{3}
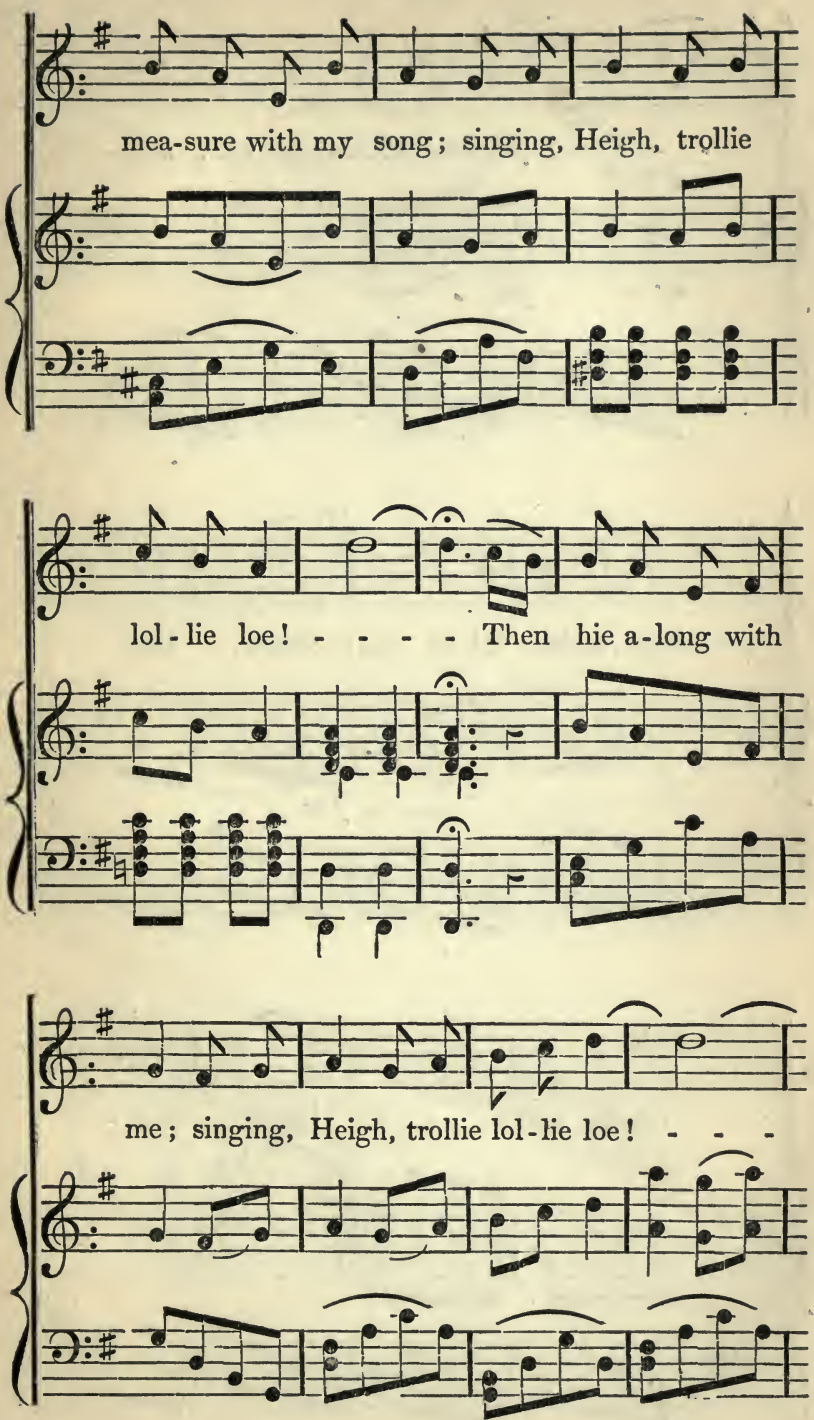

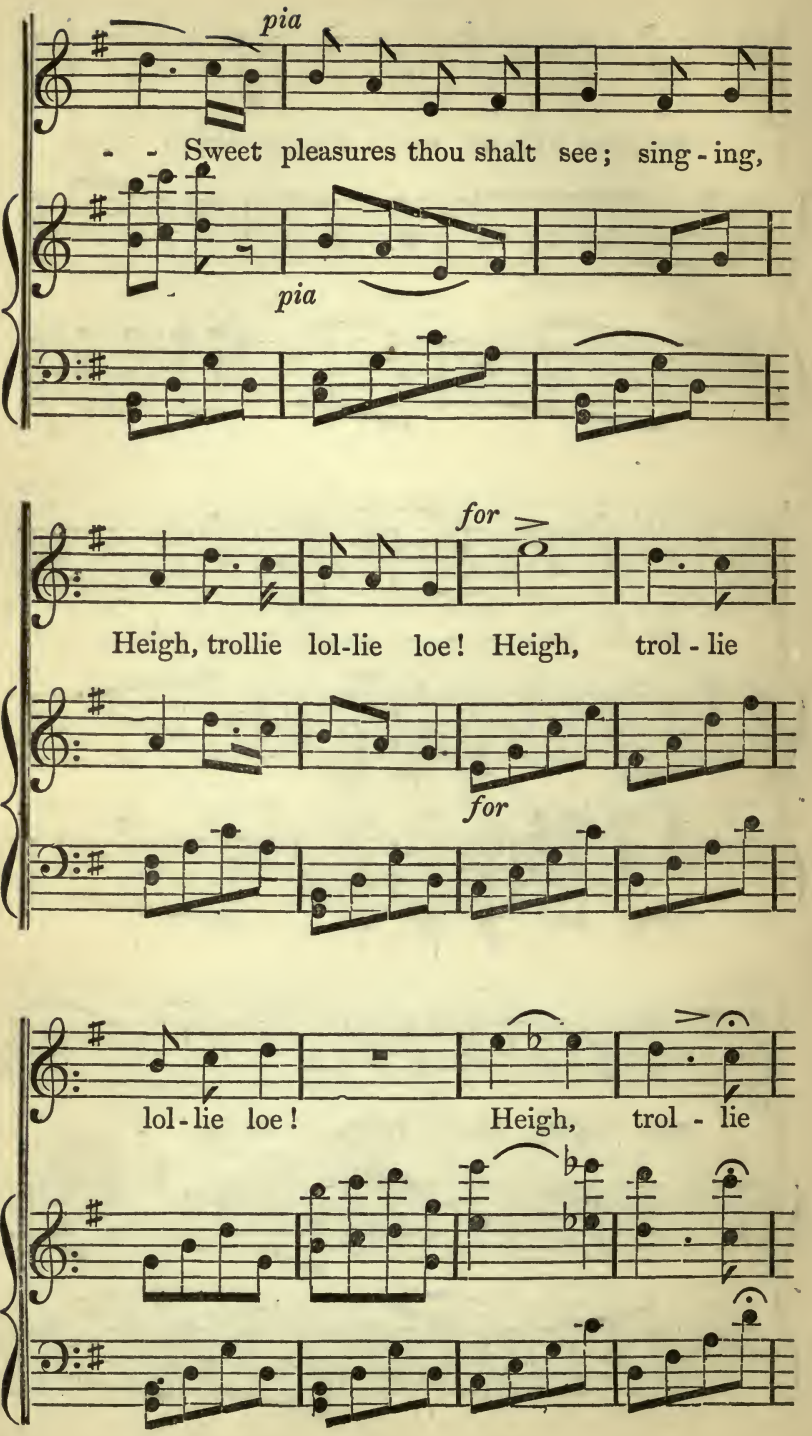


\section{5}
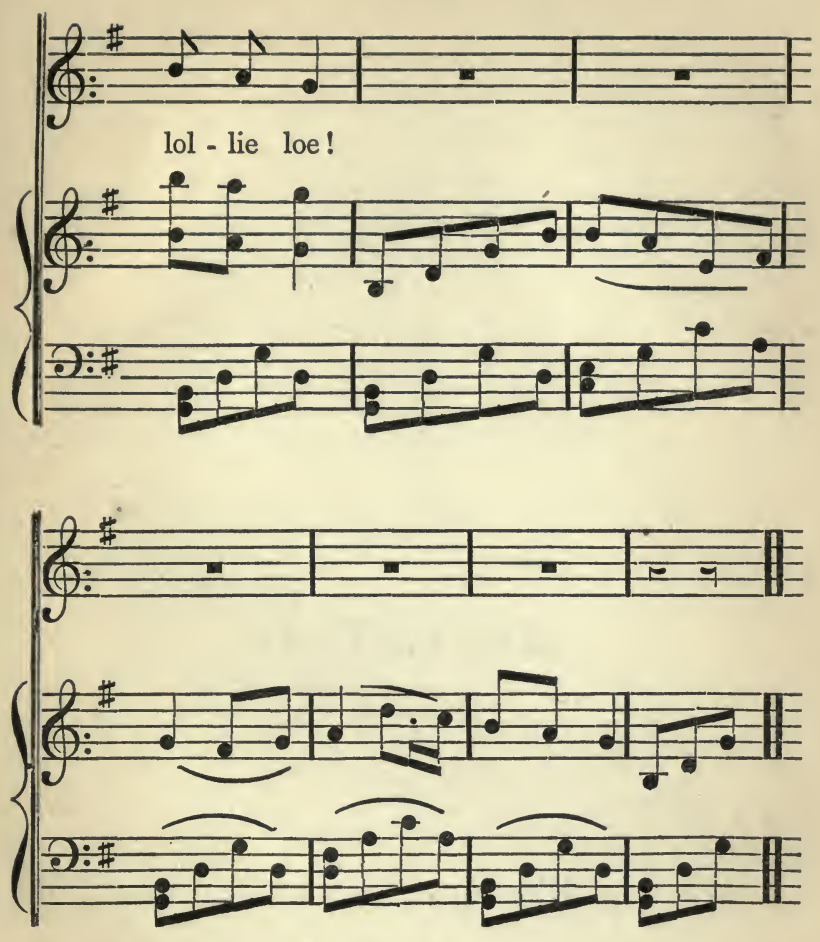



\section{SEPTEMBER.}





\section{Eeptember.}

THE herald of stern winter comes to scan our plains and groves; a spy, to ascertain when the old warrior may march his forces onwards. The frosted scout has fled with earliest morn, and dares but wait the jealous sun's approach. Rapid as thought he vanishes away, and howls his disappointment on the mountain top: there let him stay, till our hearths blaze with embers that defy his power. We thank thee, glorious orb, and keep our dear loved summer yet. The sportsman now with ready gun and everwatchful dog crosses our quiet path; a few moments and he is lost in yonder thicket, yet by the faithful echo I can trace his hot pursuit, and calculate his chances of success. How strangely opposite, mine all in silence, his with 
feverish eye and ear, and but few paces distant. Oh! could I chain thee to this stream, and rob thee of thy warlike implements, how changed a mind thou wouldst possess, and in the fair face of Heaven confess our great superiority.

The Flies are now so few and weak that it is really difficult to point out those most likely to yield sport, if I except the Black and Brown Palmer, with which, on windy days, you are pretty sure of success; the House Fly, too, may be used, of the larger kind, such as the Blue Bottle, \&c., though I cannot say I have ever seen so close a resemblance as to induce my trying it ; there exist also a few light-coloured Duns which might be added to your store, but the Palmers are in my opinion preferable.

The knell of parting summer tells me I must now take leave of you till the next year's spring, and leave the field to the busy recreation of the shot: my enthusiasm makes me wish them linked with us; for as it is, they neither enjoy our quiet, or our sunshine, our reflection, or 
our study, our invention, or our skill. Nature knits her sterile brow, nor smiles till we are called again to greet her. Mark how the clouds e'en weep at our departure, and the river sullenly rolls on in opposite direction from our homes; the songsters of the woods, too, emigrate, and heavy dews increase the melancholy gloom. Adieu, fair fields, where I have wooed the grateful shade of summer, and praised your matchless beauties; various tinted offsprings, and majestic elms, adieu ; and as thou art bid to ripen into life again, may that same mercy grant our happy meeting, for even age in smiles, looks sometimes like the spring: therefore laugh on, nor spurn my withered locks; for though my years be many, I am young at heart, and in my love for thee, kind Nature, die but in my infancy.

Let not the interim which now takes place be lost in over-thought of other things; tie afresh your Flies, finish your sketches, compose new lays that may divert your brother Anglers, 
search for fresh modes by which you may discover the Trout's secrets, and improve your skill; and more than all, forget not Him who has permitted us to revel in true enjoyment, far beyond all others, and unceasing pray that we may meet again in equal gratitude and joy, in united affection, with one heart and soul, Quit not for an instant thy innocent enjoyments for worldly fame; the one is perishable, but the other, doubt not, lasts for ever.

I ask not marble monument, or sculptured name, I seek not riches, power, or princely fame. These heed I not, but let the moments fled Live once again, and haunt me when I'm dead,The forests, flowers, the meadows, and the stream, What envied death if such my lot to dream. 


\section{SONG.}

Let us troll a merry song,

But what subject shall it be?

One that wiles away the winter

Till the spring again is free.

It will fright the cold away

To its cavern out of sight,

Till the golden blush of May

Wakes the Angler to delight.

In the student's halls, elate,

Do we sing our winter's lay, And in pleasant tales relate Happy moments fled away; Hoping on to greet the day When the gates of Heaven look bright, And the infant blushing May Wakes the Angler to delight. 



\section{SEPTEMBER.}
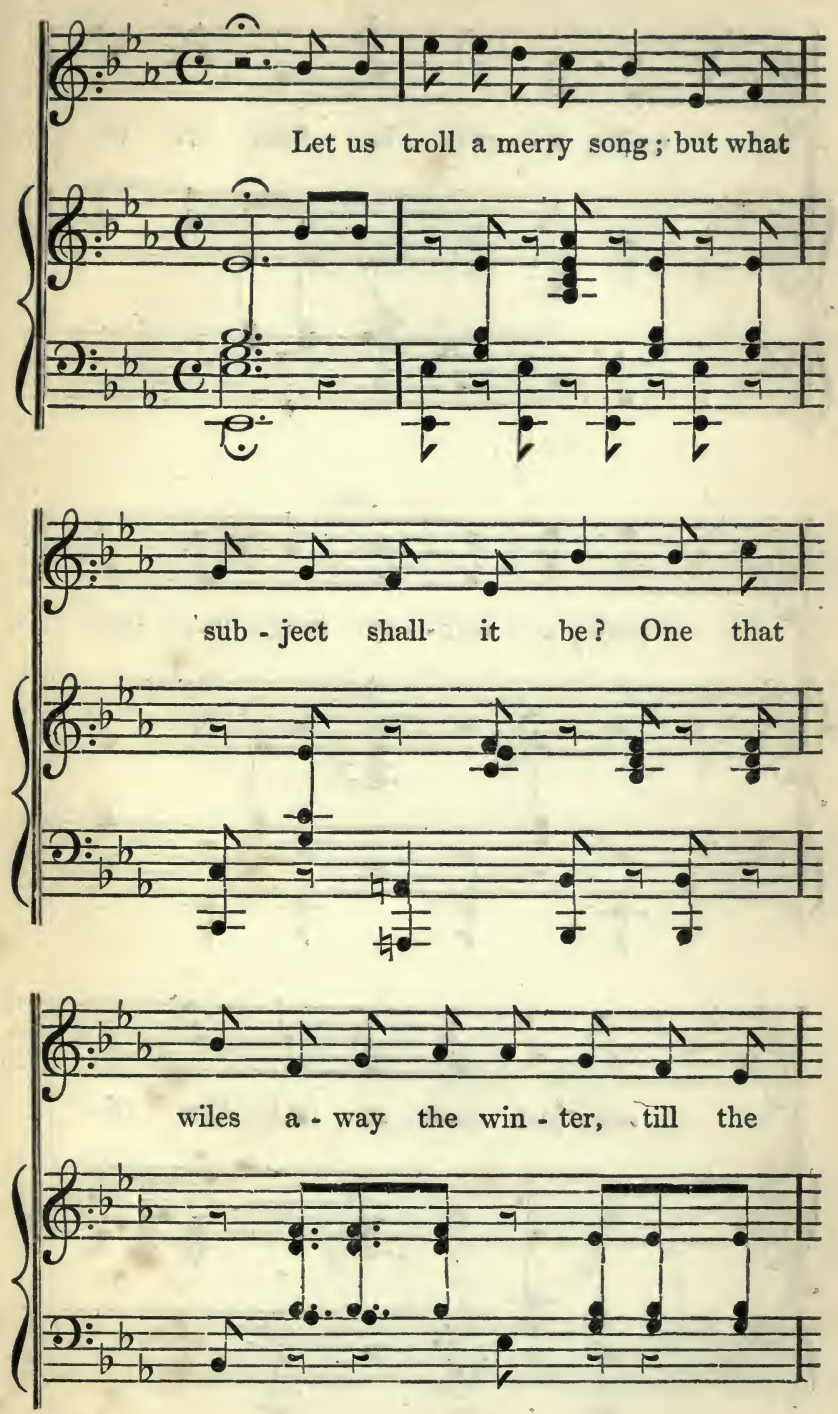

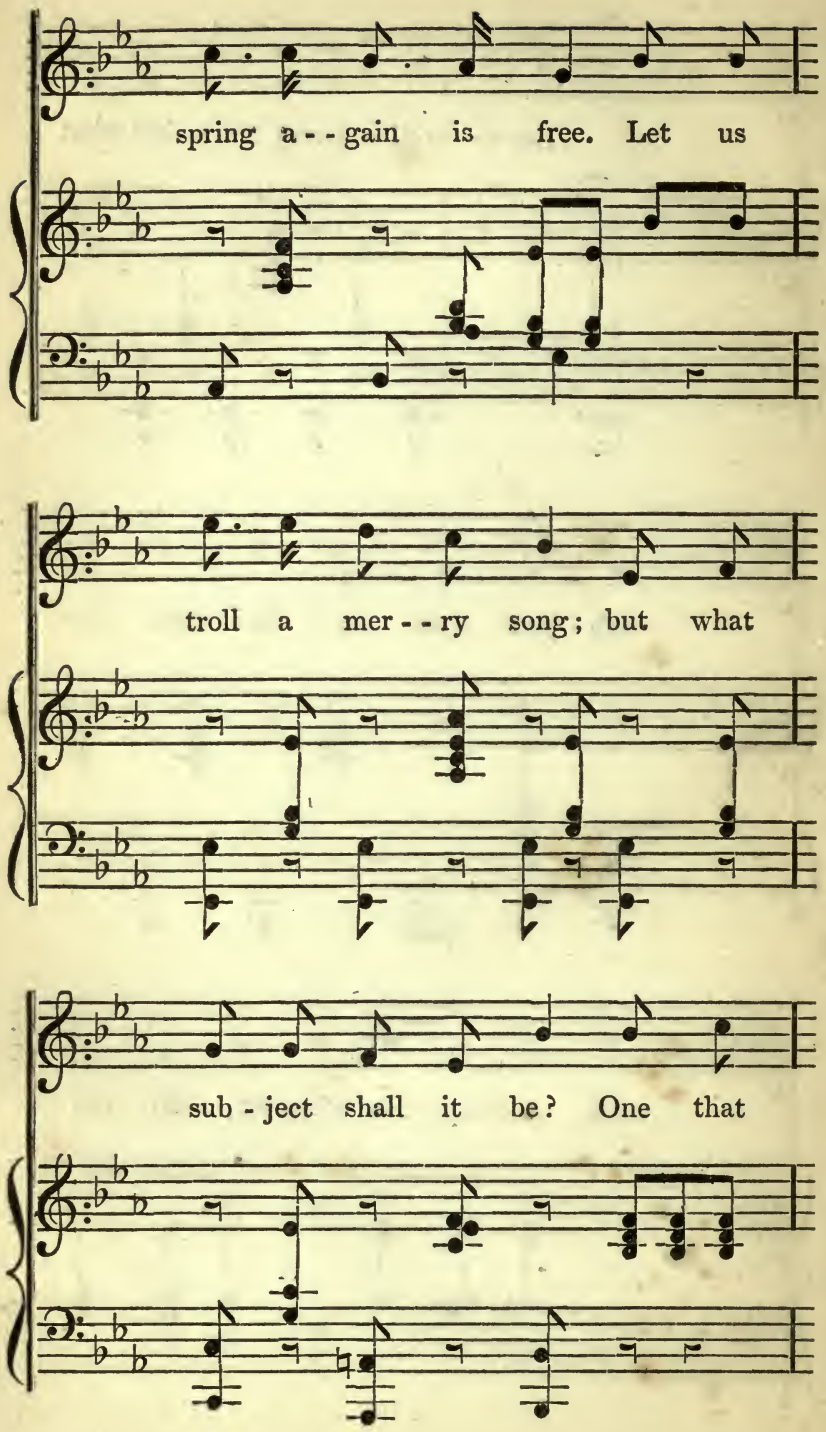

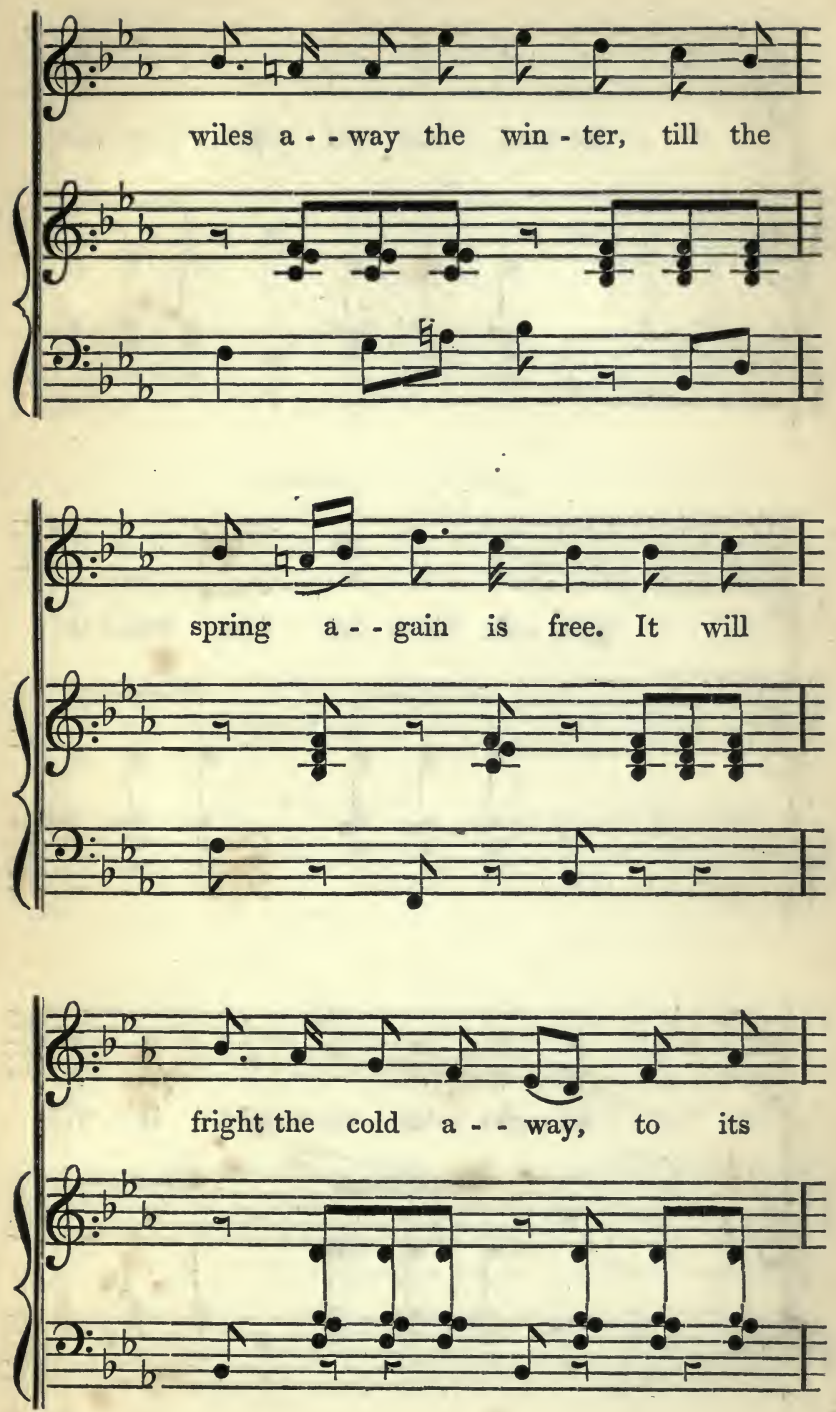


\section{8}
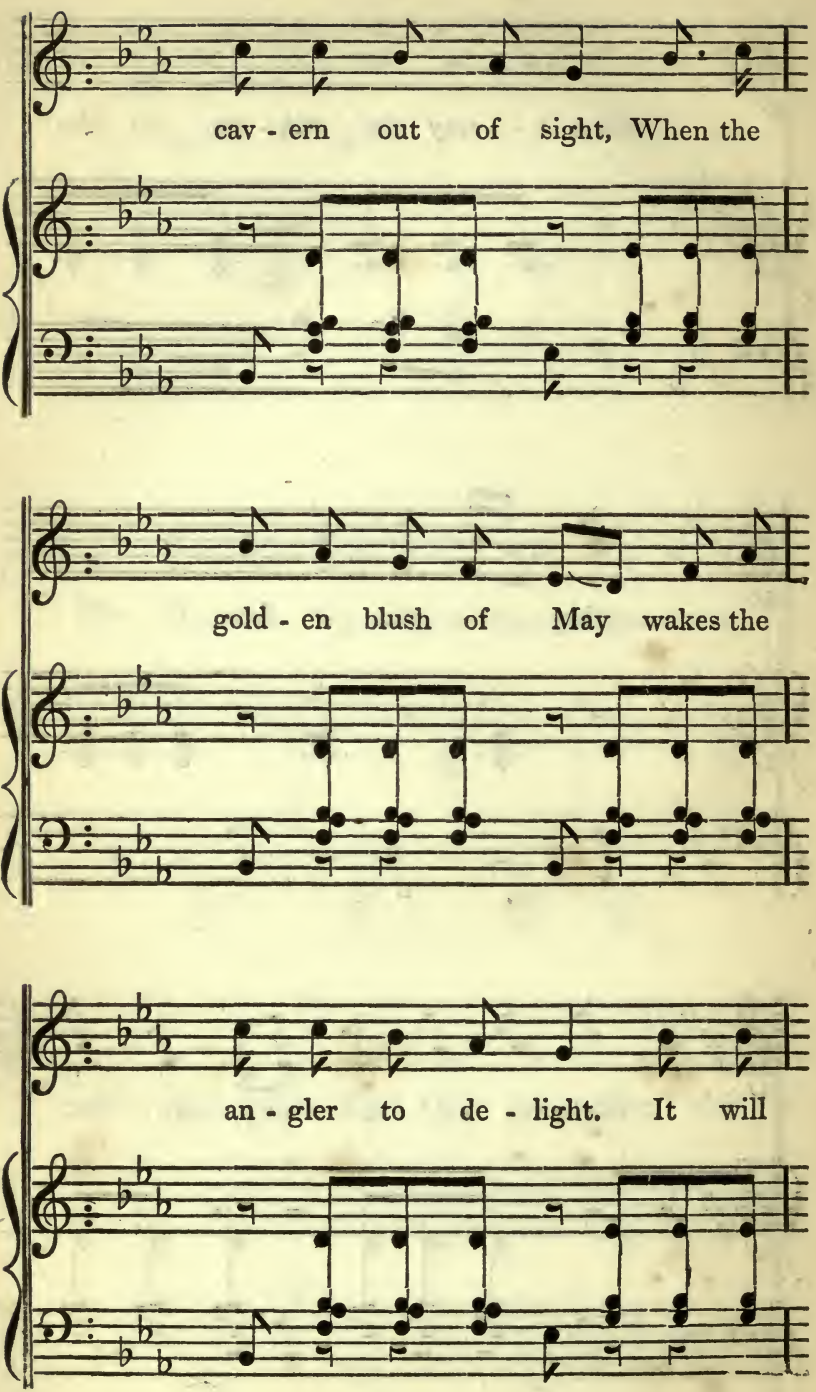

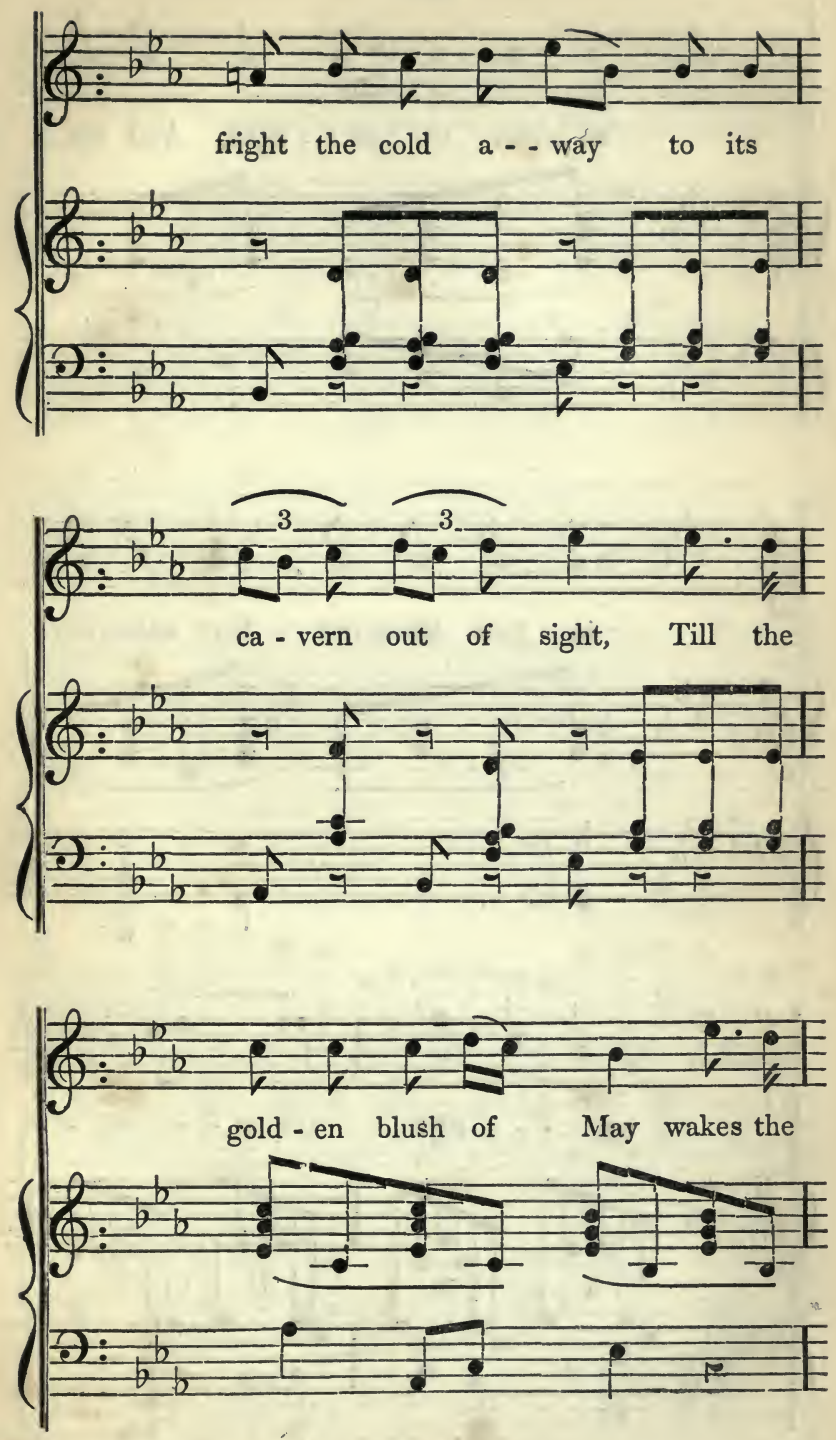

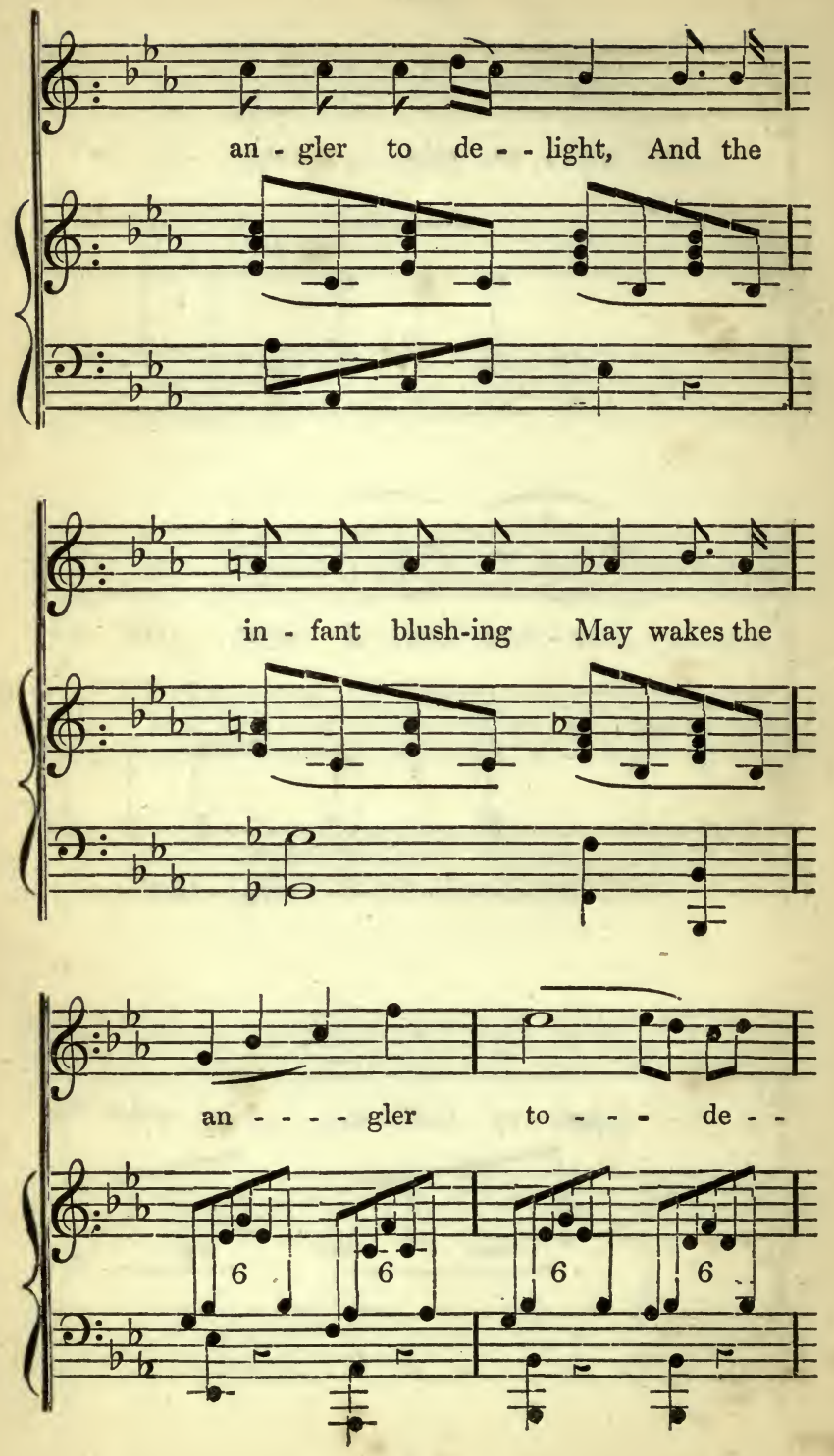

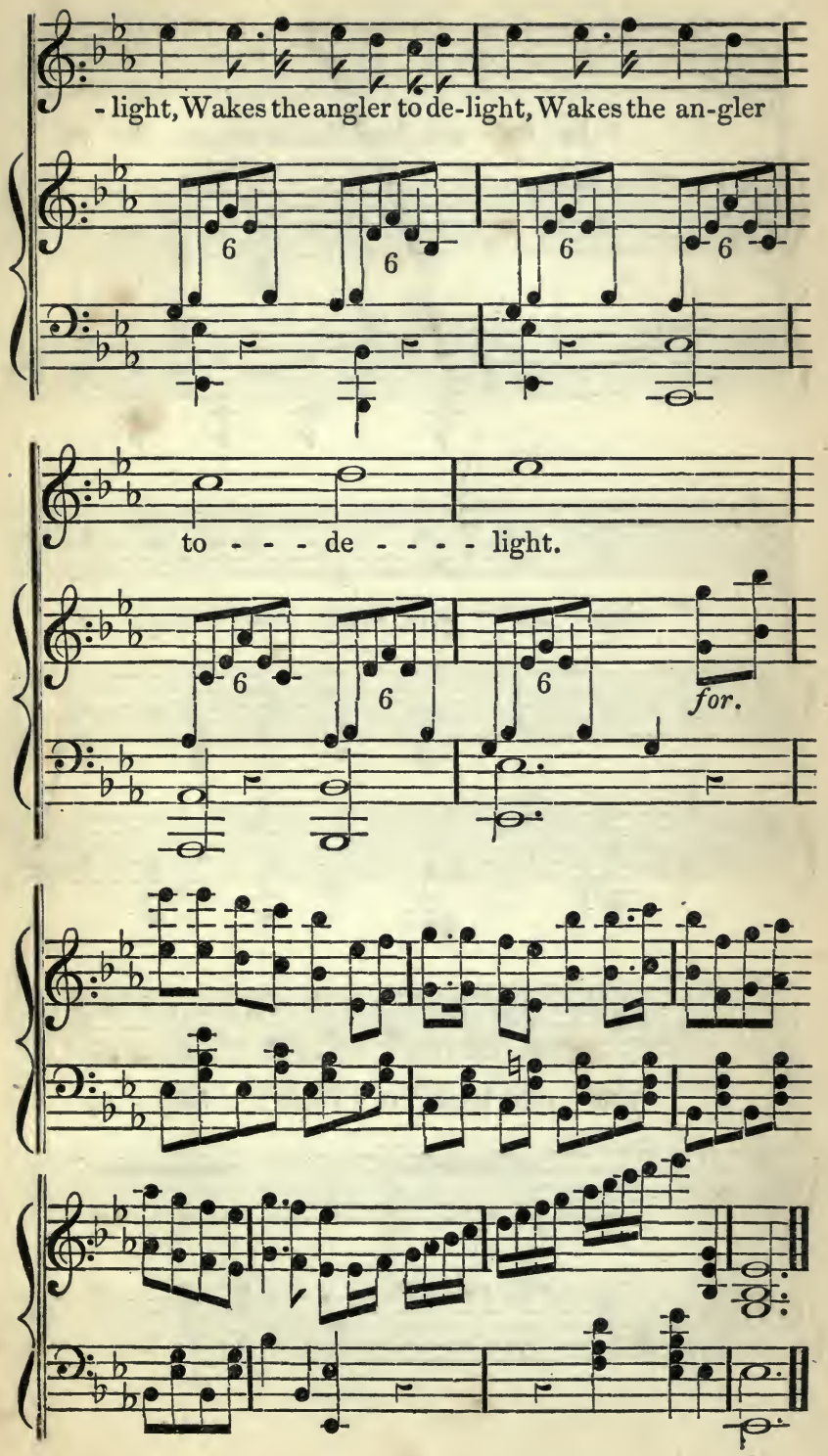

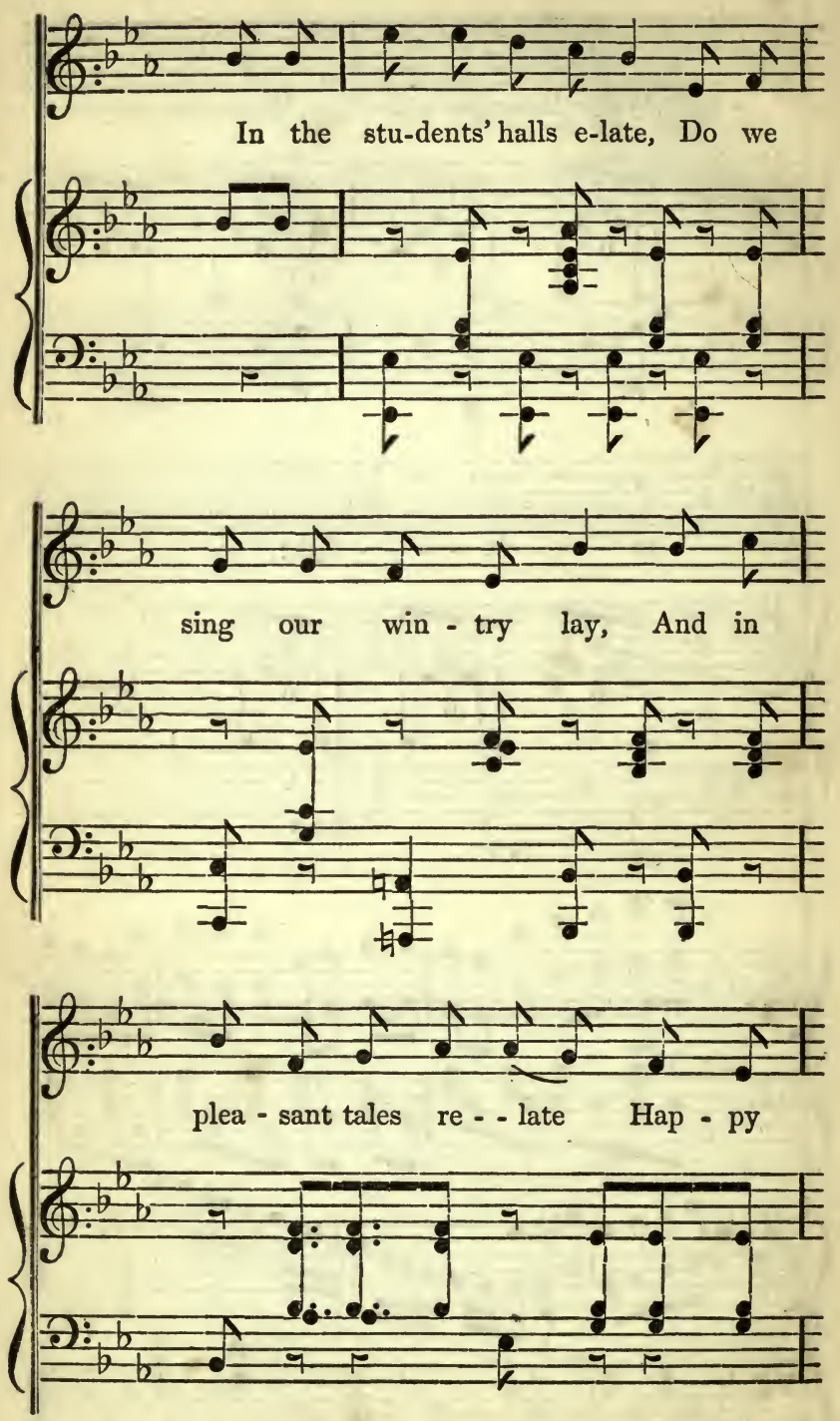

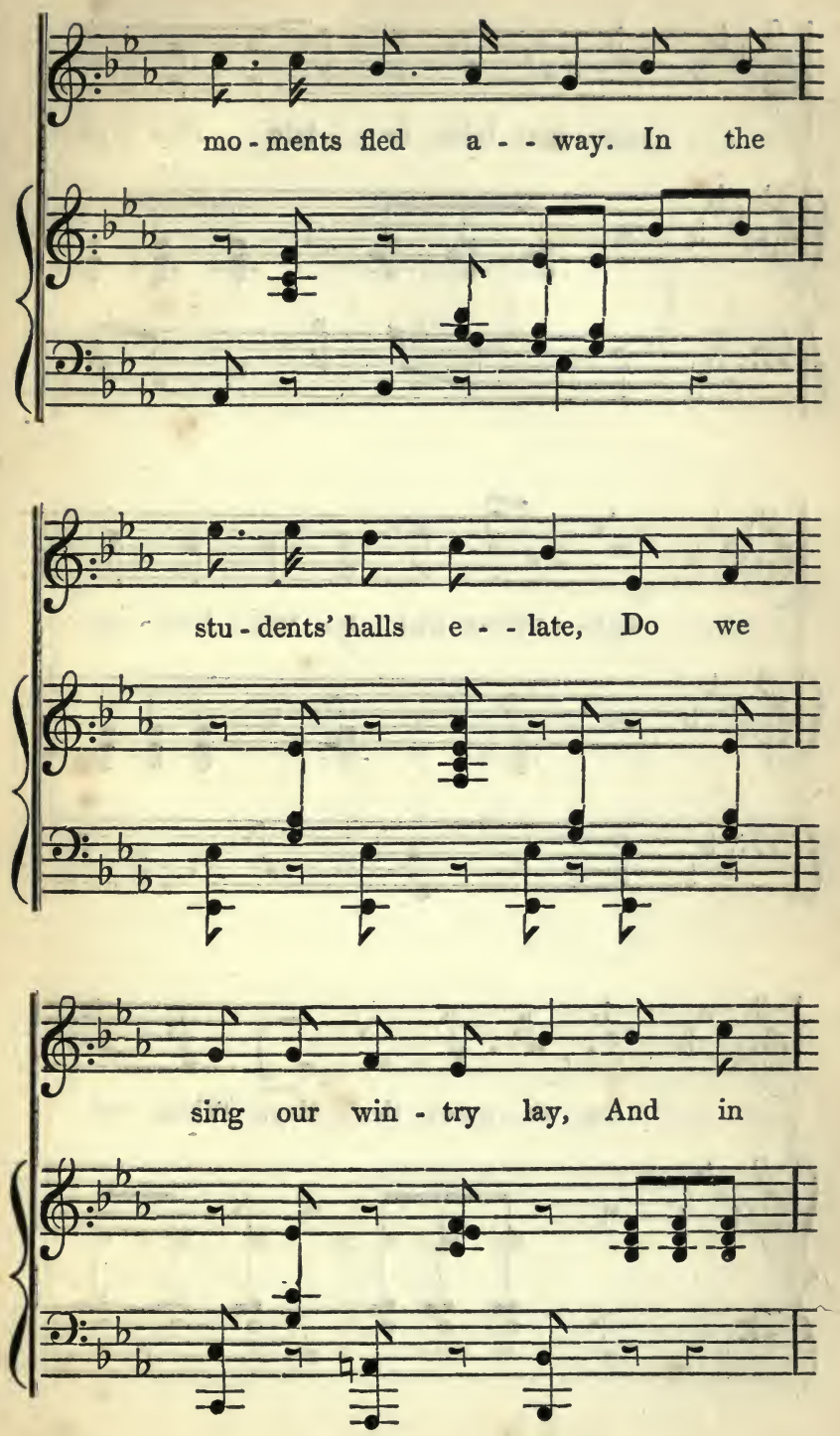


\section{4}
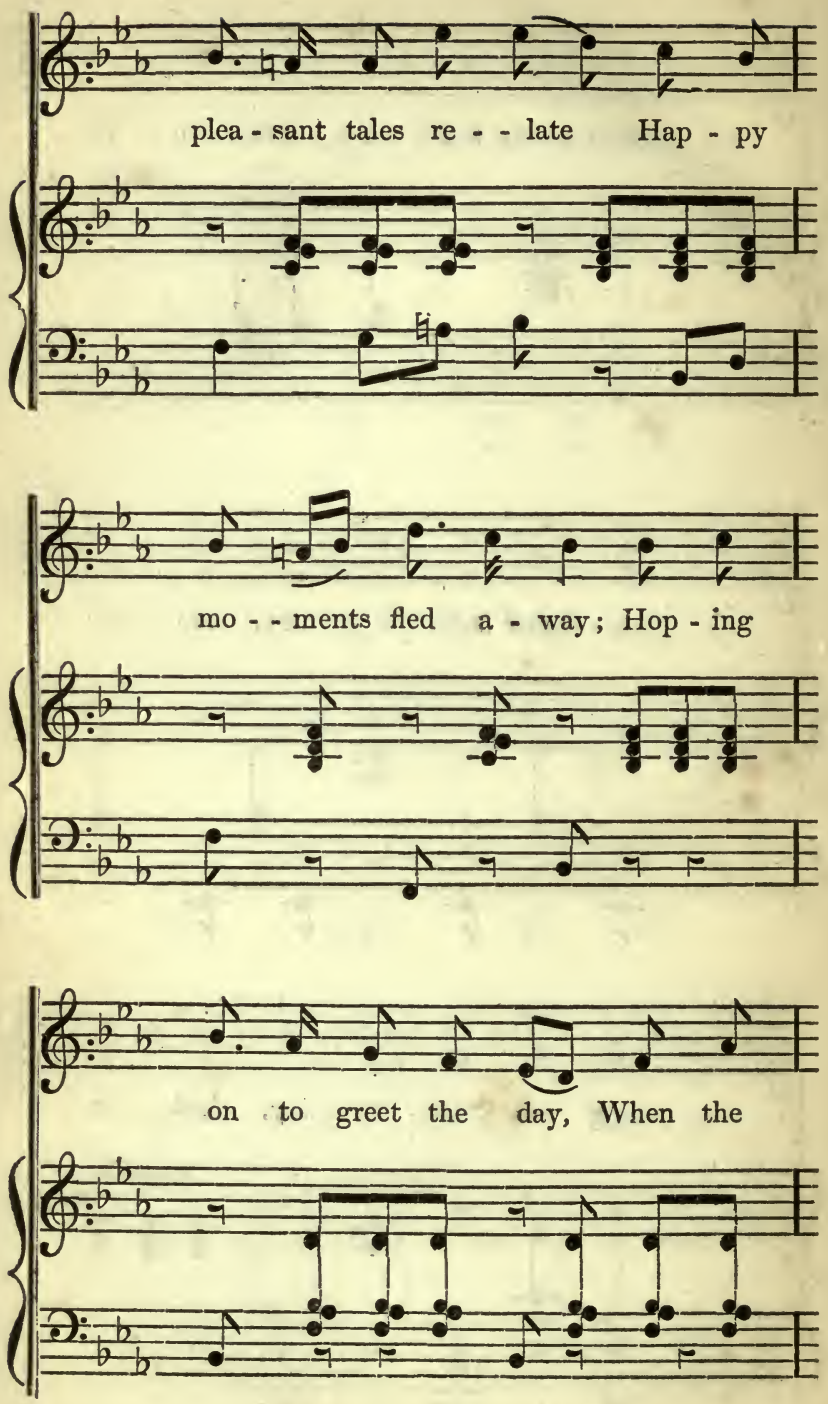


\section{5}
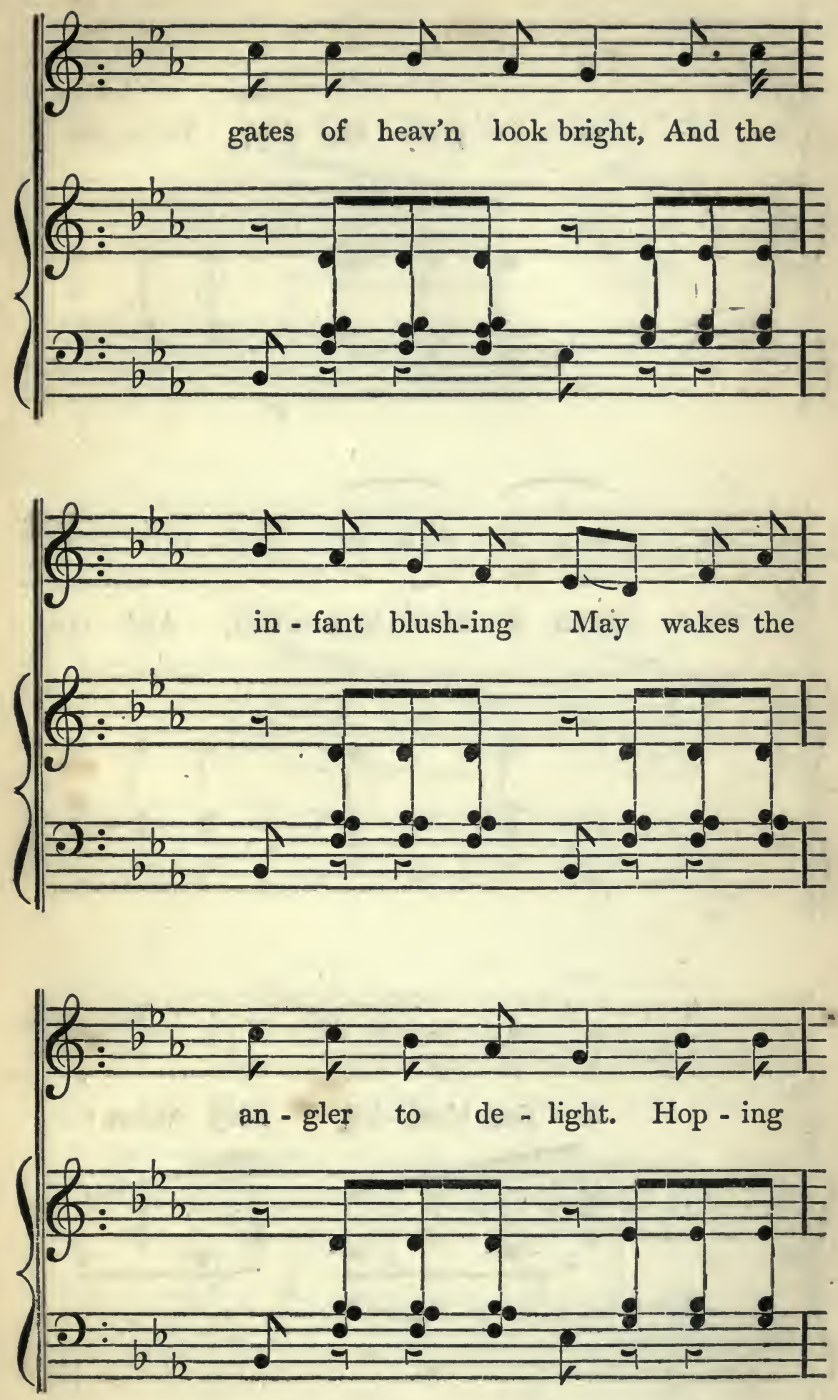
136
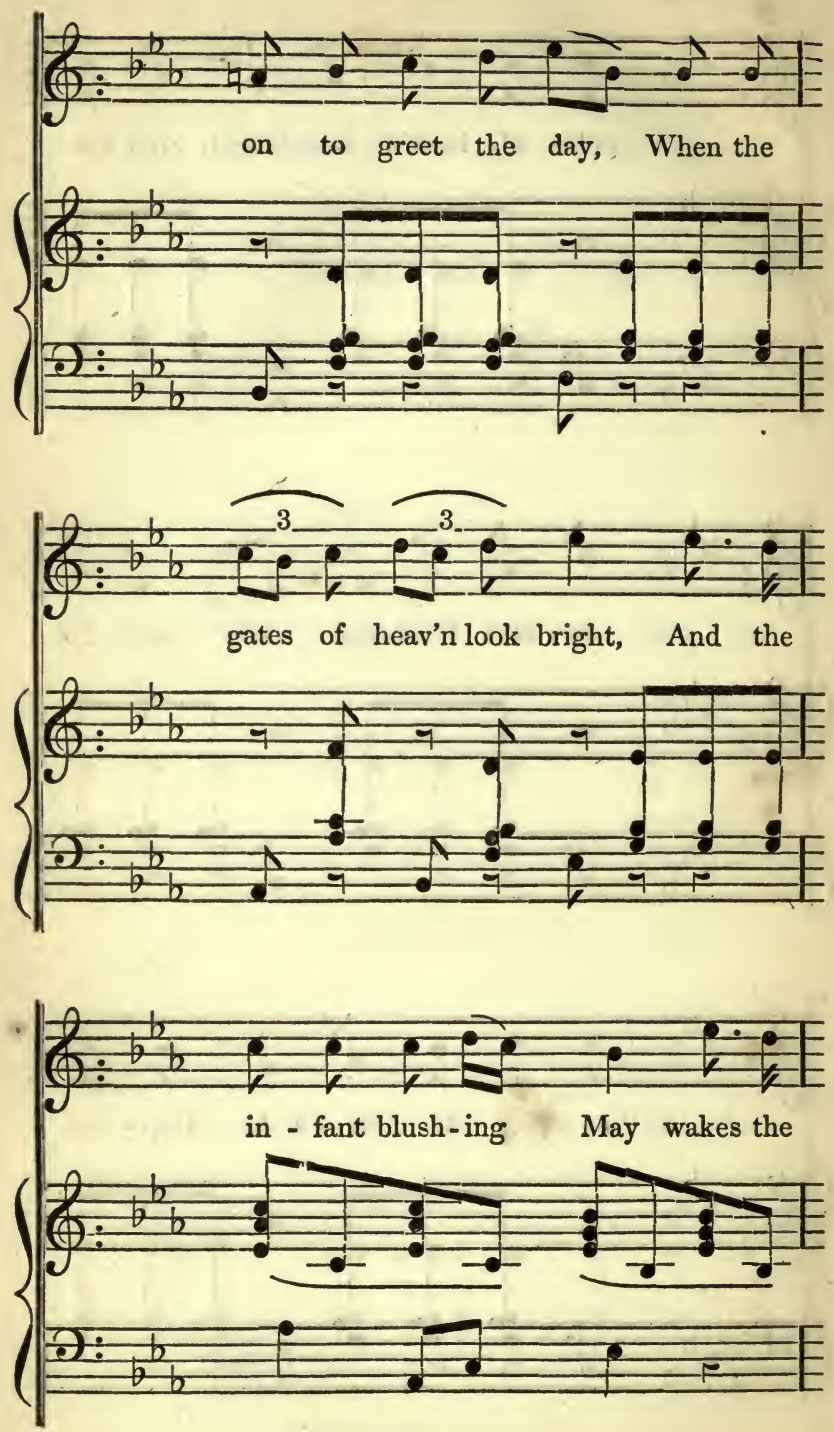

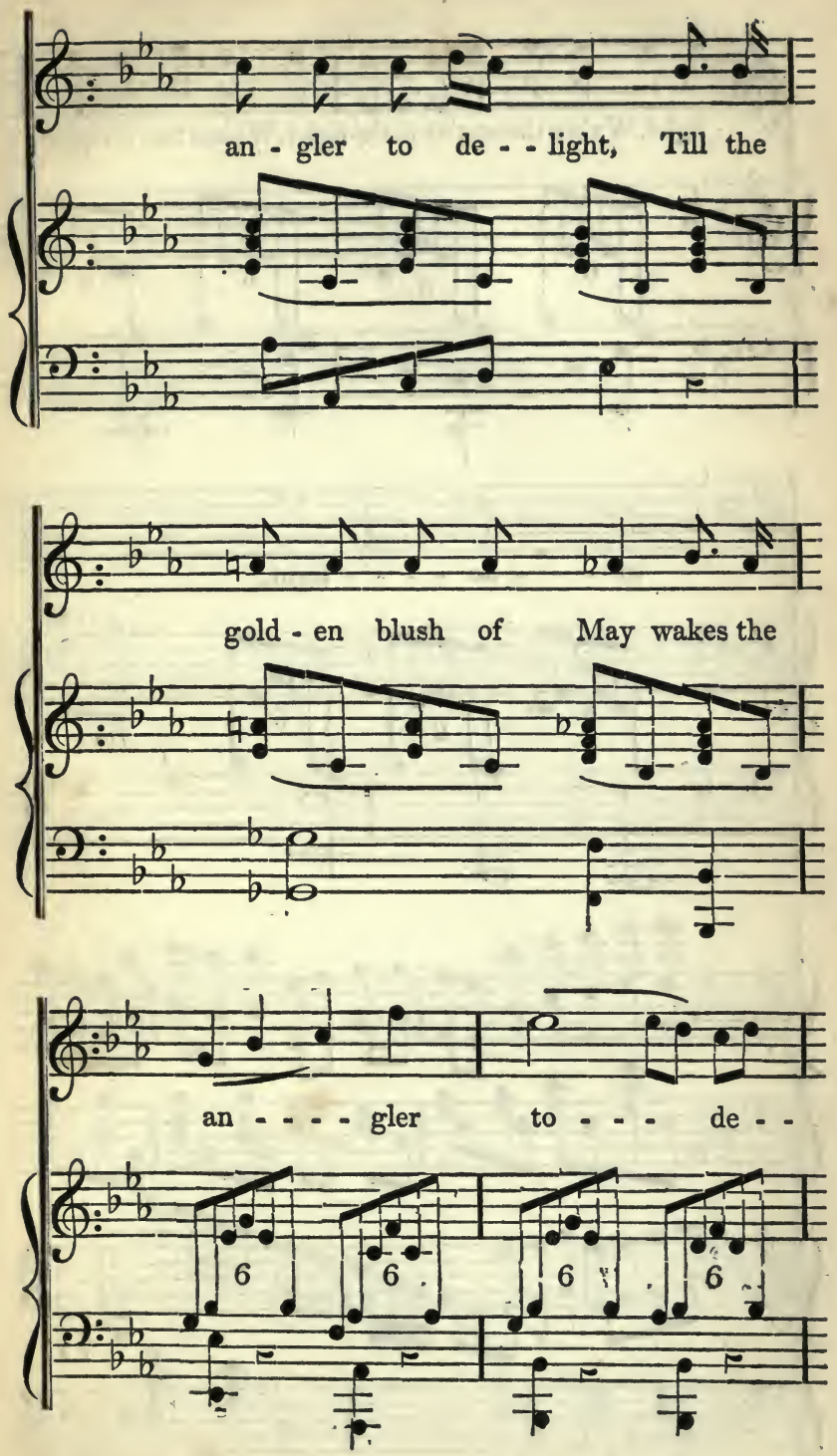

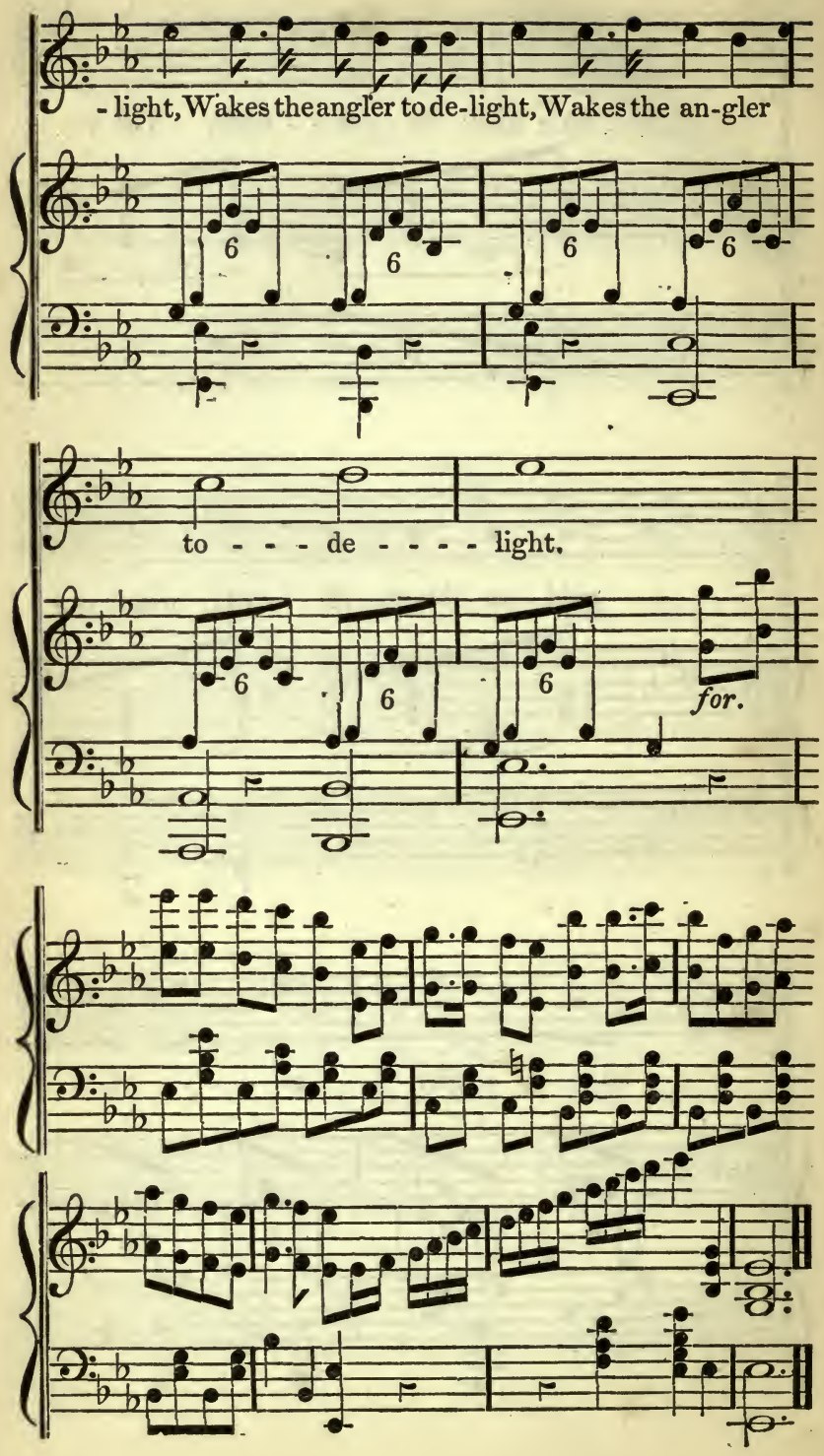



RETURN TO DESK FROM WHICH BORROWED .99'

\section{CIRCULATION DEPARTMENT}

This book is due on the last date stamped below, or on the date to which renewed. $d$ books are subject to immediate recall.

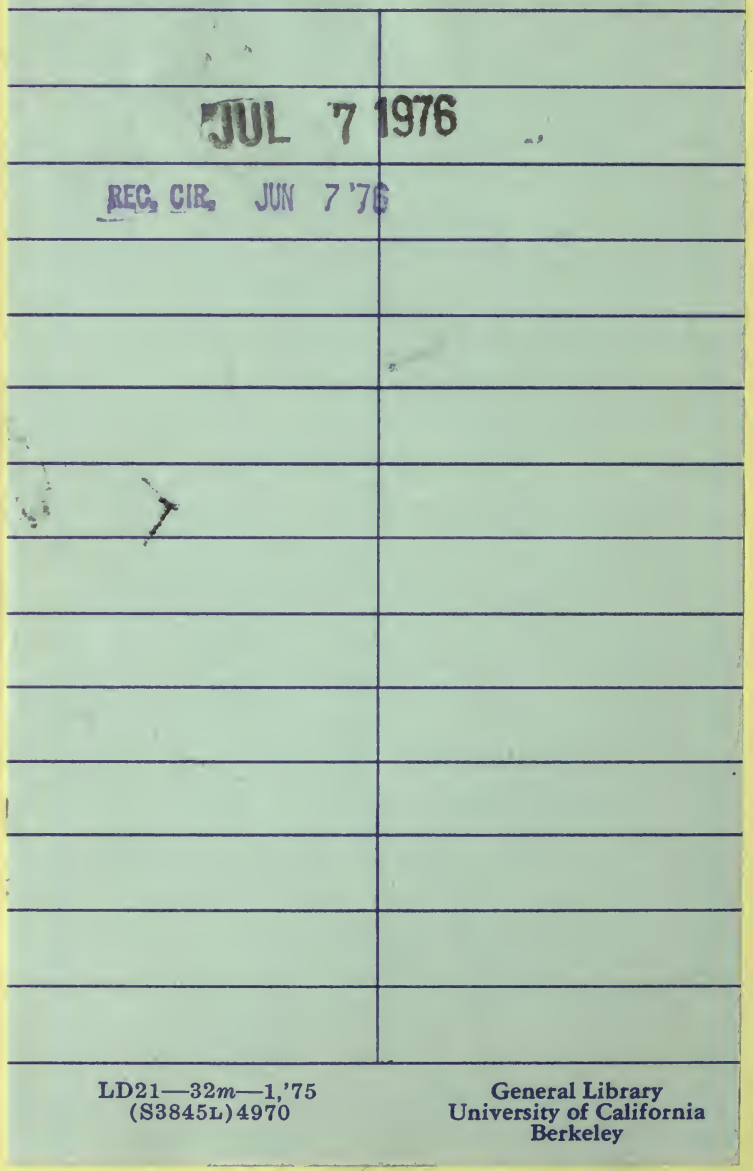



